WORKING PAPER No. 53

\title{
DISTRIBUTIONAL MEASURES
} ACROSS HOUSEHOLD GROUPS IN A NATIONAL ACCOUNTS FRAMEWORK

Results from an experimental crosscountry exercise on household income, consumption and saving 



\section{Unclassified}

STD/DOC(2013)4

Organisation de Coopération et de Développement Économiques

Organisation for Economic Co-operation and Development

06-Nov-2013

STATISTICS DIRECTORATE

English - Or. English

DISTRIBUTIONAL MEASURES ACROSS HOUSEHOLD GROUPS IN A NATIONAL ACCOUNTS FRAMEWORK

Results from an experimental cross-country exercise on household income, consumption and saving

This document has been prepared by Maryse FESSEAU (OECD) and Maria Liviana MATTONETTI (Eurostat)

Complete document available on OLIS in its original format

This document and any map included herein are without prejudice to the status of or sovereignty over any territory, to the delimitation of international frontiers and boundaries and to the name of any territory, city or area. 


\section{OECD STATISTICS WORKING PAPER SERIES}

The OECD Statistics Working Paper Series - managed by the OECD Statistics Directorate - is designed to make available in a timely fashion and to a wider readership selected studies prepared by OECD staff or by outside consultants working on OECD projects. The papers included are of a technical, methodological or statistical policy nature and relate to statistical work relevant to the Organisation. The Working Papers are generally available only in their original language - English or French - with a summary in the other.

Comments on the papers are welcome and should be communicated to the authors or to the OECD Statistics Directorate, 2 rue André Pascal, 75775 Paris Cedex 16, France.

The opinions expressed and arguments employed herein do not necessarily reflect the official views of the OECD or of the governments of its member countries or those of EUROSTAT or the European Union.

\section{www.oecd.org/std/publicationsdocuments/workingpapers/}

(C) OECD/European Union 2013

Applications for permission to reproduce or translate all or part of this material should be made to: OECD Publications, 2 rue André-Pascal, 75775 Paris, Cedex 16, France; e-mail: rights@,oecd.org 


\section{ACKNOWLEDGEMENTS}

This work has only been possible with the co-operation of country experts who participated in an OECDEurostat Expert Group, helped defining common specifications and made significant efforts to provide national results according to the common specifications.

The list of country experts involved in the Expert Group is below:

\section{National institutes}

Australia

Austria

Canada

Chile

Denmark

Finland

France

Germany

Israel

Italy

India

Japan

Korea

Mexico

Netherlands

New Zealand

Poland

Portugal

Slovenia

Spain

Sweden

Switzerland

Turkey

United Kingdom

United States

International agencies

European Central Bank

Luxembourg Income Study
Ms Amanda Seneviratne, Mr Derick Cullen, $\mathrm{Mr}$ Michael Smedes, Mr Ross Harvey, Mr Olivier Brunet, Mr Scott Jensen, Ms Jacqueline Dumpleton Mr Karl Schwarz

Ms Chantal Hicks, Ms Catherine Van Rompaey

Mr Gerzo Gallardo, Mr Juan Radrigan

Ms Nina Kristiansen

Ms Katri Soinne

Mr Sébastien Durier, Ms Lucile Richet-Mastain

Mr Albert Braakmann, Mr Florian Schwahn

Ms Tali Shalem, Ms Yafit Alfandari, Mr Oz Shimony, Mr Yoel Finkel

Ms Alessandra Coli, Ms. Francesca Tartamella

Mr Ashish Kumar, Ms Aninidita Shindaray

Mr Susumu Kuwahara, Ms Saeko Maeda

Mr Young Tai Kim, Mr Woon Sun Eo, Ms Young Ji Moon, Mr Jinho Park

Ms Martha Elena Tovar Soria, Ms Gabriela Velázquez Vera

Mr Wim van Nunspeet (Chair), Ms Mélanie Koymans, Mr Arjan Bruil

Mr Jeff Cope

Mr Mikolaj Haponuik

Ms Ana Simao, Ms Teresa Hilário

Ms Mojca Skrlec

Mr Alfredo Cristobal

Mr Andreas Lennmalm, Ms Lana Omanovic

Mr Lukas Schweizer

Ms Hilal Yentur

Mr Robert S Smith

Mr Clinton Mc Cully

Mr Ilja Kristian Kavonius, Mr Juha Honkkila

Mr Paul Alkemade

As stated above many people contributed to the work presented in this paper. In addition to those mentioned above the authors would like to thank Wim van Nunspeet for chairing the Expert Group and Peter van de Ven and Marco Mira d'Ercole for their detailed comments and suggestions on the paper.

The authors gratefully acknowledge all these contributions but remain responsible for any errors in compiling or interpreting the results. The opinions expressed and arguments employed here are the responsibility of the author(s) and do not necessarily reflect those of the OECD, Eurostat, the country experts and their organisations. 


\begin{abstract}
Valuable information exists already on household economic resources. The national accounts provide aggregate measures and micro sources (surveys, administrative records, and censuses) can be used to derive measures of the distribution across households groups. Over the years, however, macro and micro statisticians have tended to work separately leading to sometimes divergent results which can cause problem to users. In 2011, the OECD and Eurostat launched a joint Expert Group to carry out a study on the feasibility of compiling measures of the distribution of income, consumption and wealth across household groups that are consistent with national accounts definitions and totals. As part of the Expert Group, national experts from 16 countries performed experimental calculations using all the detailed micro and macro information available at the national level and following the same framework and methodology. The experimental results obtained are presented in this paper. They show disparities in household income and consumption, including Social Transfers in Kind, and in household saving for different groups of households: by income quintile; by main source of income; and by household type. The main methodological issues related to this exercise are described. The paper also illustrates the number of assumptions that are required to produce estimates on distribution across households consistent with national accounts definitions and totals.
\end{abstract}

Keywords: National accounts, Household, Survey, Income, Consumption, Saving.

\title{
RESUME
}

Les données macro-économiques des comptes nationaux fournissent des données agrégées sur le revenu, la consommation et l'épargne de l'ensemble des ménages. Les sources microéconomiques (enquêtes, données administratives et recensement) informent sur la manière dont le revenu et la consommation sont réparties entre les ménages. Au fil des années cependant, les statisticiens micro et macro ont eu tendance à travailler séparément conduisant parfois à des résultats divergents et rendant le travail d'analyse compliqué pour les utilisateurs. En 2011, l'OCDE et Eurostat ont lancé un groupe de travail conjoint afin d'étudier la possibilité de produire des indicateurs sur la distribution des ressources économiques des ménages qui soient cohérents avec les totaux et les définitions des comptes nationaux. Dans le cadre de ce groupe de travail, des experts nationaux de 16 pays ont produit des estimations combinant les informations micro et macro disponibles au niveau national et en suivant une méthode harmonisée. Les résultats, encore expérimentaux, sont présentés dans ce papier. Ils portent sur les inégalités de revenu, de consommation, incluant les transferts sociaux en nature, et d'épargne pour différents groupes de ménages selon le quintile de revenu, la principale source de revenu ou le type de ménage. Les principales difficultés méthodologiques rencontrées dans ce type d'exercice sont présentées. Le papier détaille également les hypothèses nécessaires pour produire des indicateurs de distribution cohérents avec les totaux et définitions des comptes nationaux.

Mots clés: Comptes nationaux, Ménage, Enquête, Revenu, Consommation, Épargne. 


\section{CONTENTS}

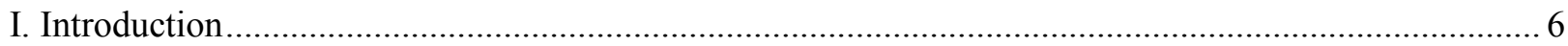

II. Breakdown of the household accounts by household groups ........................................................... 7

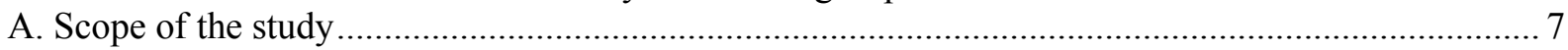

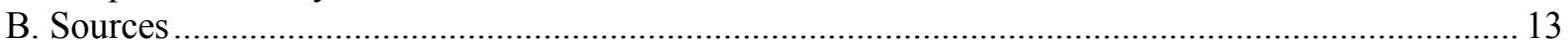

C. Methodology used to distribute SNA totals among different groups of households ....................... 15

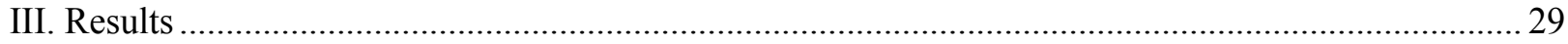

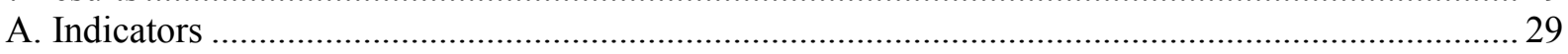

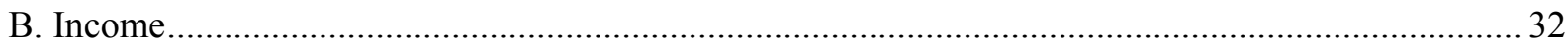

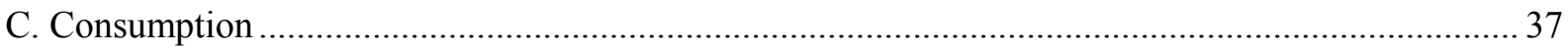

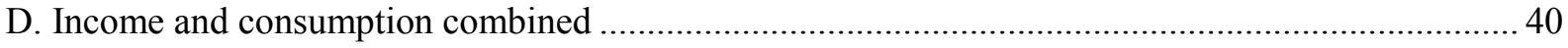

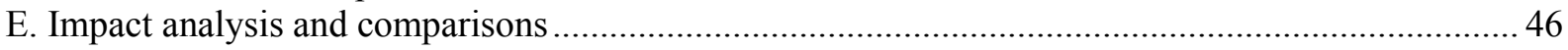

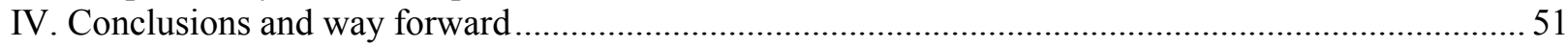

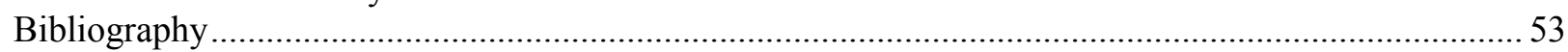

Annex 1 - Definition of the national accounts aggregates and components ..........................................5 54

Annex 2 - Expert Group template: household groups ……................................................................ 56

Annex 3 - Expert Group template: list of components ........................................................................ 61

Annex 4 - Breakdown - method and adjustment coefficients by component and by country .................. 63

Annex 5 - Impact of the household structure on the disparity index .................................................. 70

Annex 6 - Impact of benchmarking micro income variables to national accounts totals ...................... 73

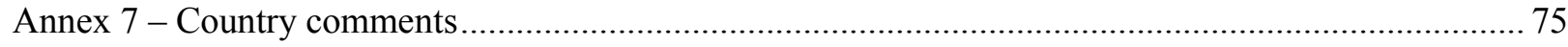

See also:

Micro sources used: main characteristics and sample sizes available at: http://www.oecd.org/std/WP-STD-2013-4-1.xlsx

Demographic information: number of households and number of consumption units available at: http://www.oecd.org/std/WP-STD-2013-4-2.xlsx

Detailed results by country available at: http://www.oecd.org/std/WP-STD-2013-4-3.xlsx 


\title{
DISTRIBUTIONAL MEASURES ACROSS HOUSEHOLD GROUPS
}

IN A NATIONAL ACCOUNTS FRAMEWORK

\section{Results from an experimental cross-country exercise on household income, consumption and saving}

\author{
Maryse FESSEAU (OECD) and Maria Liviana MATTONETTI (Eurostat)
}

\section{Introduction}

1. It has long been recognised that Gross Domestic Product (GDP) and other macro-economic indicators, while useful in their own right, are not suitable measures to depict people's material conditions in any comprehensive sense. The report of the Commission on the Measurement of Economic Performance and Social Progress, the "Stiglitz-Sen-Fitoussi Commission", stressed the importance of a greater focus on the household perspective in order to provide better measures of people's well being. The report recommended emphasizing measures of household living standards including distributional concerns. The G-20 Data Gaps Initiative which aims at closing information gaps highlighted by the economic and financial crisis also made a number of recommendations encouraging the compilation of more detailed household measures.

2. Whilst the System of National Accounts (SNA) provides a framework for the compilation and analysis of statistics on household income, consumption and wealth, the accounts depict conditions for an "average" household and, so, cannot describe differences between households. Average measures of household income per person or per household do not give any information about how available resources are distributed, which is critical for the design of economic and social policies.

3. Measures of the distribution of income, consumption and wealth are provided by micro data, e.g. surveys, administrative records and censuses. But for many reasons such as differences in concepts, definitions and statistical practices, micro data can yield results that diverge from macro aggregates. This means that measures created using these data sources may not be consistent with the figures in national accounts.

4. Studies in a number of countries show that information on distribution across households consistent with SNA aggregates can be performed using the information available in micro sources (see Fesseau M. and Le Laidier S. (2010) and CBS (2011)). To capitalise on these experiences and to meet growing policy demands, the OECD and Eurostat launched in 2011 a joint Expert Group which aimed to explore whether it is possible to devise an internationally comparable methodology to produce measures of disparities across different household groups that are consistent with national accounts concepts and totals using existing micro data sources.

5. As part of the Expert Group, national experts from sixteen countries (Australia, France, Germany, Israel, Italy, Japan, Korea, Mexico, the Netherlands, New Zealand, Portugal, Slovenia, Sweden, Switzerland, Turkey and the United States) performed experimental calculations using all the detailed 
micro and macro information available at the national level and following, to the extent possible, the same framework and methodology ${ }^{1}$.

6. This methodological paper presents the methodology and results from the Expert Group study. For the first time, experimental results on household disparities in a national accounts framework are presented for several OECD countries. This paper makes clear how a better use of existing micro sources by national accounts compilers could usefully improve the household national accounts by showing distributional measures consistent with the current description of the average household. Measures of disparities in household income and consumption, including Social Transfers in Kind, and in household saving are presented for different groups of households: income quintile; main source of income; and household type. The main methodological issues related to this exercise are described. The paper also illustrates the number of assumptions that are required to produce estimates on distribution across households consistent with national accounts definitions and totals.

7. Section 2 of this paper presents how national experts performed the breakdown of the household accounts according to national accounts by household groups, detailing the scope of the study, the sources used and the method applied. Section 3 presents the results for household income, consumption and for measures combining income and consumption such as the saving rate. Section 4 concludes and suggests some possible ways forward.

\section{Breakdown of the household accounts by household groups}

8. This section describes how national experts proceeded to perform the breakdown of national accounts aggregate among different household groups. The first subsection describes the scope of the study, the second provides more details on the sources used and the third explains the methods applied.

\section{A. Scope of the study}

9. In this paper, the breakdown of household accounts is done for three household classifications and for one given year. This subsection describes the part of the household accounts studied, defines the household groupings used, and presents the Expert Group template that national experts compiled for one given year.

\section{The household national accounts as benchmark}

10. The System of National Accounts (SNA) is the international standard used to compile measures of economic activity, such as Gross Domestic Product (GDP). The SNA provides a framework that describes how the income generated by economic production is distributed as income to the various institutional sectors, e.g. Households, Non Profit Institutions Serving Households (NPISH), Financial and NonFinancial Corporations and General Government. The sequence of accounts shows the process of distributing and redistributing income between the various institutional sectors allowing them to consume goods and services or to acquire goods and services for later consumption.

11. This paper focuses on the household accounts, with a particular interest on household income, consumption and saving. National accounts data provide information on various components of income flows received and paid by households (e.g. wages and salaries, social benefits, income taxes), on types of household expenditures (e.g. food, clothing, housing), and on a number of aggregates that are economically significant. Table 1 is a tabular presentation of the main items available in the household accounts on

1 In parallel to the Expert Group work, Eurostat launched a similar study, the "a-minima" exercise, carried out at the centralized level by making use of the information available at Eurostat. 
income, consumption and saving, and describes how the transactions are aggregated in the national accounts framework. Further details on definitions are provided in Annex 1. Definitions for the key aggregates are given below:

- Household primary income represents what accrues to households as a consequence of their involvement in processes of production or ownership of assets that may be needed for purposes of production. Compensation of employees is a major item of primary income of households. It represents the total earnings from labor input, while employees, and includes social contributions paid by employers on behalf of their employees. The primary income contains also an element corresponding to remuneration for work carried out by the owner (or members of his family) of owned - unincorporated enterprises which cannot be distinguished from his profits as entrepreneur. This is referred to as 'mixed income'. Property income received and paid by lending or renting financial or natural resources, including land, to other units for use in production also affect the primary income.

- Household disposable income can be derived from primary income by adding net current transfers (i.e. social benefits in cash and other current transfers received minus social contributions and taxes paid).

- Household final consumption expenditures covers all purchases made by resident households at home or abroad to meet their everyday needs: these include purchases for food, clothing, housing services (rents), energy, transport, durable goods (notably cars), spending on health, on leisure and miscellaneous services. The reference classification used by national accounts compilers is the Classification of Individual Consumption according to Purpose (COICOP).

- Household saving represents the part of disposable income (adjusted for the change in pension entitlements ${ }^{2}$ ) that is not spent on final consumption of goods and services.

12. The SNA includes an alternative concept for measuring household income and consumption that takes into account spending by general government and NPISH that benefit households. These Social Transfers in Kind (STiK) include the expenditure by general government and NPISH on the provision of various individual services (health care, education, etc.) and the reimbursement of household purchases of goods and services (such as medical consultations and medicines as well as housing rentals). The relevant alternative national accounts aggregates are called household adjusted disposable income and actual final consumption, which correspond, respectively, to household disposable income and final consumption expenditure to which STiK are added (Table 1).

13. For each of the above aggregates and components, the national accounts provide information on totals for the resident population. "A household is defined as a group of persons who share the same living accommodation, who pool some, or all, of their income and wealth and who consume certain types of goods and services collectively, mainly housing and food. In general, each member of a household should have some claim upon the collective resources of the household. At least some decisions affecting consumption or other economic activities must be taken for the household as a whole" [SNA 2008, $\S 4.149]$. "Persons living permanently in an institution, or who may be expected to reside in an institution for a very long, or indefinite, period of time are treated as belonging to a single institutional household when they have little or no autonomy of action or decision in economic matters. Some examples of persons

2 The adjustment for net equity in pension funds is necessary because of the way contributions paid to pension funds and pension benefits received from these funds, are treated in national accounts. They are recorded as current expenditure/income, while on the other hand they are also considered as a kind of (dis)saving, adding to the value of pension entitlements. To include both views on pensions, the income point of view and the wealth point of view, and to bridge them, an adjustment had to be introduced. This dual treatment concerns employment-related pension schemes. It is not relevant for individual life insurance schemes, for which neither the contributions nor the benefits are recorded as current expenditure/income; they are only recorded as a financial transaction. 
belonging to institutional households are the following: members of religious orders living in monasteries, convents or similar institutions; long-term patients in hospitals, including mental hospitals; prisoners serving long sentences; persons living permanently in retirement homes" [SNA 2008, §4.152]. The household sector also includes the income generated by unincorporated enterprises owned by households and for which no separate accounts can be compiled.

14. The goal of the Expert Group was to assess the practical feasibility of producing disparity measures consistent with the SNA framework, using the available data sources. To do so, national experts agreed to stick as much as possible to the SNA definitions and totals, although a few experts expressed doubts on the importance of strictly adhering to the national accounts when studying household inequality (see Box 1).

Table 1: Income, consumption and saving: main transactions and relationships in the national accounts framework using the associated codes $^{3}$

INCOME

\begin{tabular}{|l|l|l|}
\hline Income resources - received by households & \\
\hline B2 & Operating surplus from actual and imputed rentals & \\
\hline B3 & $\begin{array}{l}\text { Mixed income from owned unincorporated enterprises } \\
\text { and from own account production }\end{array}$ & \\
\hline D1 & $\begin{array}{l}\text { Compensation of employees, including social } \\
\text { contributions }\end{array}$ & \\
\hline D4 & Property income , e.g. interest, dividends, rents on land & \\
\hline Income uses - paid by households & \\
\hline D4 & Property income, e.g. interest, rents on land & \\
\hline B5 & Primary income & $=$ B2+B3+D1+ D4 resources - D4 uses \\
\hline Income resources - received by households & \\
\hline D62 & Social benefits in cash & \\
\hline D7 & Other current transfers & \\
\hline Income uses - paid by households & \\
\hline D5 & Current taxes on income and wealth & $=$ B5+D62+D7resources-D5-D61-D7uses \\
\hline D61 & Social contributions & $=$ B6+D63 \\
\hline D7 & Other current transfers & \\
\hline B6 & Disposable income & Social Transfers in Kind \\
\hline D63 & Adjusted disposable income & \\
\hline B7 &
\end{tabular}

\begin{tabular}{|l|l|l|}
\hline P3_01 & Food and non-alcoholic beverages & \\
\hline P3_02 & Alcoholic beverages, tobacco and narcotics & \\
\hline P3_03 & Clothing and footwear & \\
\hline P3_04 & Housing, water, electricity, gas and other fuels & \\
\hline P3_05 & $\begin{array}{l}\text { Furnishings, household equipment and routine } \\
\text { household maintenance }\end{array}$ & \\
\hline P3_06 & Health & \\
\hline P3_07 & Transport & \\
\hline P3_08 & Communication & \\
\hline P3_09 & Recreation and culture & \\
\hline P3_10 & Education & \\
\hline P3_11 & Restaurants and hotels & \\
\hline
\end{tabular}

3 The SNA distinguishes different types of transactions among which the transaction in products, coded $\mathrm{P}$, and the distributive transactions, coded $\mathrm{D}$. The main aggregates that are derived from the accounts are coded B. The Classification of Individual Consumption according to Purpose (COICOP) gives a code number to each different type of expenditures. 


\begin{tabular}{|l|l|l|}
\hline P3_12 & Miscellaneous goods and services & \\
\hline P33 & Resident household expenditure abroad & \\
\hline P34 & Non-resident household expenditure on the territory & \\
\hline P3 & $\begin{array}{l}\text { Final consumption expenditure of resident } \\
\text { households }\end{array}$ & $\begin{array}{l}\text { P P3_01+P3_02+P3_03+P3_04+ } \\
\text { P3_05+P3_06+P3_07+P3_08+ } \\
\text { P3_09+P3_10+P3_11+P3_12 + P33_P34 }\end{array}$ \\
\hline D63 & Social Transfers in Kind & \\
\hline P4 & Actual final consumption & P3 + D63 \\
\hline
\end{tabular}

SAVING

\begin{tabular}{|l|l|l|}
\hline D8 & Change in net equity of households in pension funds & \\
\hline B8 & Saving & $=\mathrm{B} 6+\mathrm{D} 8-\mathrm{P} 3=\mathrm{B} 7+\mathrm{D} 8-\mathrm{P} 4$ \\
\hline
\end{tabular}

\section{Box 1: Relevance of the national accounts framework when studying household economic conditions}

Taking the national accounts definitions and totals as a benchmark when developing disparity indicators among household groups may be justified by three main reasons. Firstly, household data from national accounts have the advantage of being fully consistent with economy-wide measures such as GDP. Secondly, the SNA framework covers household income, consumption and wealth in an integrated way, and is well harmonized across countries. Thirdly, the national accounts totals may be expected to be of higher quality that those from micro-sources due to the focus of national accounts on getting at consistent and exhaustive estimates.

The latter justification is, however, debatable. Indeed, the robustness of national accounts totals depends on how totals are estimated (see Fesseau M., Wolff F. and Mattonetti M-L. (2013)). For some income and consumption components, these totals may be estimated simply as a residual from the transactions of the other sectors in the economy, without using sources that refer specifically to households. SNA totals may also be adjusted to ensure consistency and/or to take into account the non-observed economy.

Also, there are two other arguments that may justify some departure from national accounts. Firstly, household accounts are compiled in the SNA in a way that is consistent with other sectors of the economy. This may imply that the household accounts include components that are useful to describe the economy as a whole or to describe another group of agents, but that are not directly relevant when the focus is on the economic behaviour of households (e.g. indirect charges for financial intermediation services allocated to households). On the other hand, the household accounts may also exclude a number of components that would be of interest when focusing on households (e.g. one may want to include pensions received from individual life insurance schemes in the income definition). Secondly, while SNA definitions may be of interest when studying households as a whole, they may be of less interest when studying household disparities. In particular, including Social Transfers in Kind when studying inequalities was considered by a few Expert Group members as non relevant, as the higher income associated to Social Transfers in Kind corresponds to higher needs of households, especially in case of health and education.

The purpose of the Expert Group was not to assess the relevance of the SNA to study household disparities but to explore whether it is possible to produce measures of disparities across household groups sticking to the SNA concepts and totals. In this respect it should be noted that an OECD Expert Group was created, in parallel to the Expert Group on measuring disparities in national accounts, to develop an international framework for micro statistics on the distribution of household income, consumption and wealth. The 'ICW Framework' has been developed and is detailed in a report recently released (OECD (2013)). The micro framework has much in common with the SNA. However, while trying to maintain consistency with the SNA-definitions, it departs from the SNA in some aspects because of its focus on micro statistics. For example, the ICW framework does not include Financial Intermediation Services Indirectly Measured (FISIM), while it recommends including Social Transfers in Kind in the analysis. 


\section{Three alternative household classifications}

15. The SNA suggests several breakdowns of households: according to income level, characteristics of a reference person, household size and location. In this respect, the SNA recognizes that «There are many useful ways in which the household sector may be sub-sectored [...] individual countries are obliged to make their own decisions about what they consider to be the most relevant classification. Thus, the fact that a specific, detailed classification according to a criterion of interest is proposed here should not be interpreted as implying that the characteristics proposed are necessarily or always the most important for purposes of economic analysis and policymaking» (SNA2008, §4.158 - 4.159).

16. As part of the Expert Group work, the choice of the household groupings results from a trade-off between four goals pursued: i) identify households groups that have different consumption/saving patterns; ii) identify the richer/poorer households in a country; iii) allow users to easily identify themselves in a single group and to compare income/consumption components across groups; and iv) involve as many Expert Group countries as possible in the feasibility study and ensure cross country comparability. The three criteria used in this paper to categorize households, described in further detail in Annex 2, are:

- Equivalized household disposable income quintile (EDI): Households are classified according to the level of their equivalized disposable income. The Oxford-modified equivalence scale (also called the OECD-modified scale) is used to equivalize disposable income. This scale assigns a value of 1 to the household head, of 0.5 to each additional adult member - aged 14 and over - and of 0.3 to each child aged below 14. Households have been ranked according to the value of the equivalized disposable income and allocated to five equal groups (quintiles), each of them containing $20 \%$ of all households.

- Main source of income (MSI): Households are classified according to the main source of income for the household as a whole. The four income sources identified are wages and salaries, income from self-employment, net property income ${ }^{4}$, and current transfers received.

- Household type (HT): Households are classified according to three criteria: the number of adults in the household; the age of the adults; and the presence of children living at home ${ }^{5}$. Eight household subgroups are distinguished: a) single person under the age $65 ; b$ ) single person aged 65 and over; c) one adult with children living at home, whatever the age of the adult; d) two adults both under the age of 65 and without children living at home; e) two adults with at least one aged 65 and over, and without children living at home; f) two adults with less than three children living at home whatever the age of the adults; g) Two adults with at least three children living at home whatever the age of the adults; $h$ ) and other household types. The latter group includes households with more than two adults such as households where grandparents live with their children and grandchildren.

17. The two income classifications EDI and MSI are based on a classification of households according to their cash or near cash disposable income, which excludes rental equivalence of owneroccupied housing, Social Transfers in Kind, imputed property income such as investment income earned by insurance policy holders, and financial intermediation services indirectly measured (FISIM) ${ }^{6}$. These items were omitted when defining household groups to be closer to users' perception and for reasons of data availability. As a consequence, the income variable used to classify households is not fully consistent with the national accounts aggregates that are allocated among groups and which include these components.

$4 \quad$ Net refers here to property income received minus property income paid.

5 Both individuals under the age 16 and individuals aged between 16 and under 25 and who are offspring of one member of the households are considered as children living at home.

6 Definitions of these items are provided in Annex 1. 
18. To classify households according to EDI and MSI, national experts made use of the micro income variables available in micro sources for wages and salaries, income from self-employment, property income received and paid, and current transfers received and paid that are included in the cash or near cash disposable income. Before classifying households into these groups, the micro income variables were benchmarked to national accounts totals (Annex 2).

19. For all three household classifications, the household is the unit of analysis, the household being defined in the template as people living in the same dwelling and having a common budget.

\section{Template completed for a given year}

20. The breakdowns of the household accounts presented in this paper consisted of allocating the national accounts totals for the resident population into sub-totals by household groups, for each of the three household criteria described above. To the extent possible, the breakdown was performed by national experts for twenty income components, twenty-six types of consumption expenditure and three subcomponents of Social Transfers in Kind. Associated to each group, information on number of households and number of consumption units was provided.

21. Table 2 shows a simplified representation of the Expert Group template that was (partially or fully) completed by sixteen countries, namely Australia, France, Germany, Israel, Italy, Japan, Korea, Mexico, the Netherlands, New Zealand, Portugal, Slovenia, Sweden, Switzerland, Turkey and the United States, for one given year. The choice of the year depended on data availability ${ }^{7}$ (see part II.B). The detailed Expert Group's template is presented in Annex 3.

Table 2: Simplified template used by the members of the Expert Group

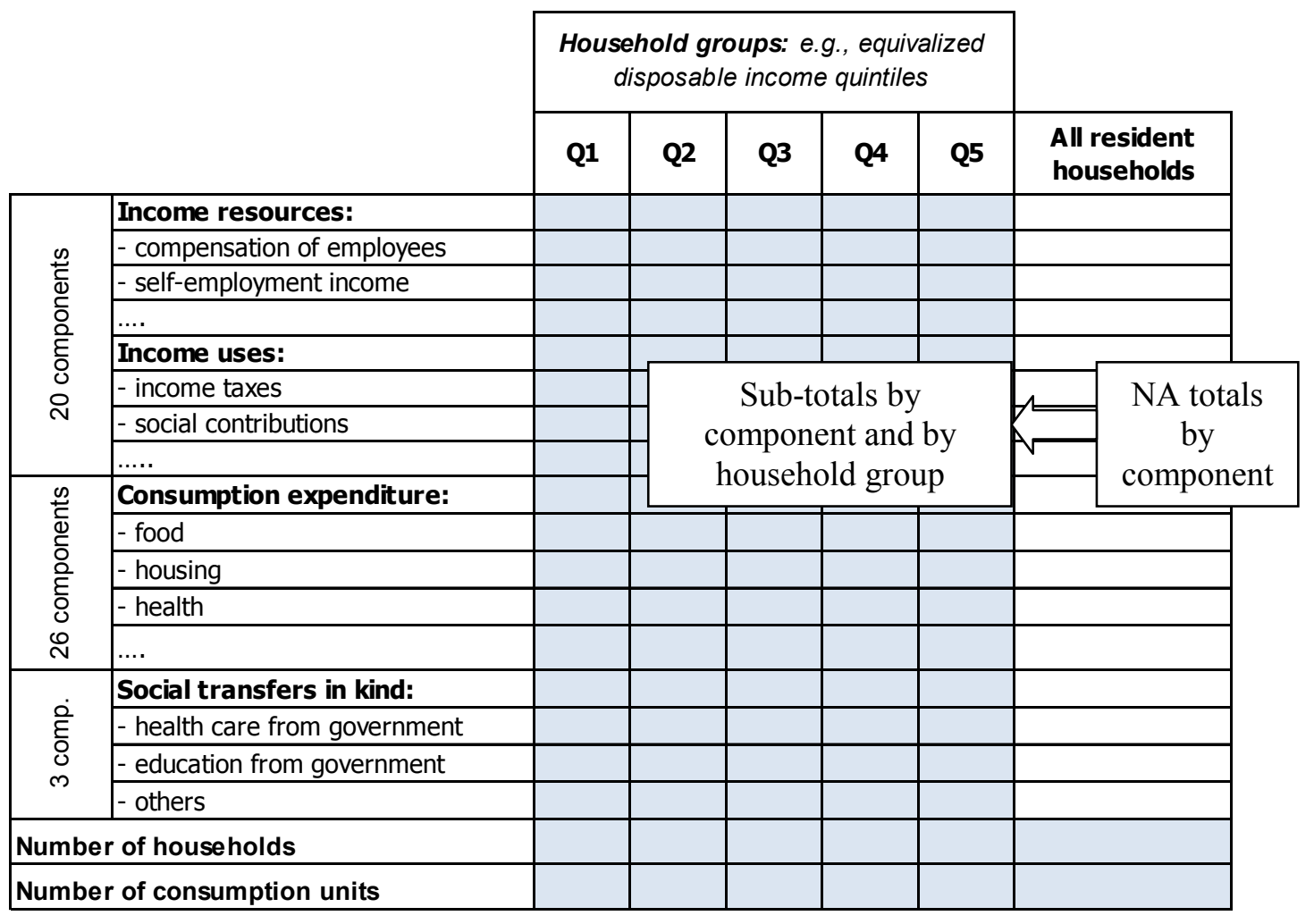

$7 \quad$ For European countries, to the extent possible, 2008 was used to facilitate the comparison with the Eurostat a-minima exercise, which was carried out for 2008. 


\section{B. $\quad$ Sources}

22. To complete the Expert Group's template two types of sources have been used: 'macro sources', i.e. national accounts totals, and 'micro sources', namely household surveys and administrative data that provide distributional information at the household level. This sub-section briefly describes the two types of sources used.

\section{At the macro level the SNA household accounts}

23. To complete the Expert Group's template, national experts used National Accounts totals for the various components of income, consumption and Social Transfers in Kind. For some countries, however, the available national accounts data contains some shortcomings. The three main issues refer to data availability, population scope, and the scope of the consumption expenditure estimates at detailed level.

24. Availability - The availability of a set of household accounts covering detailed income and consumption components as defined in the template varies across countries. Estimates of household adjusted disposable income are not yet available for Turkey and Israel. Also, in a few other countries participating in the Expert Group, national accounts compilers do not estimate total for the income and consumption components as detailed in the Expert Group template. For instance, Switzerland combines operating surplus and mixed income. As a result, no separate national accounts totals are available and the breakdown had to be performed at a more aggregated level of components than the template (Annex 3).

25. Population scope - A few countries only produce accounts for a combined sector that includes both households and NPISH (e.g. political parties, trade unions, consumers associations, recreational or sports clubs, charities, relief or aid agencies). This aggregation is based on the notion that, as these institutions are largely financed by households and their purpose is to serve households, their accounts can be assimilated to those of households. The aggregation of households and NPISH is also explained by a lack of sources on NPISH activities. As NPISH constitutes a relatively small sector, their inclusion in the household accounts is expected to have a marginal impact on the final results. The inclusion of NPISH in totals concerns Australia, Germany, Korea and Switzerland with respect to the income components and Australia with respect to consumption.

26. Consumption estimates - The template used by the Expert Group detailed twenty-six types of expenditure for which totals should be allocated between household groups. In most countries, however, national accounts data for households' final consumption expenditure by type of goods and services include expenditures of non-resident households on the territory of the country and exclude expenditures by resident households abroad. Usually, an adjustment is made in national accounts to domestic consumption (i.e. expenditure on the territory) to derive national consumption (i.e. expenditure by resident households). However, this adjustment is only made at the aggregate level, and not at the level of detailed components of consumption expenditure. Among the sixteen countries, only three produce national accounts data for resident households' expenditures by type of expenditure (Australia, Switzerland and New Zealand).

\section{At the micro level, household surveys}

27. To complete the template, national experts used micro data sources providing information on the economic resources of individual households. Experts focused on micro sources which provided information closest to the national accounts concepts. Priority was given to the most recent year available, or to the most recent year for which there was information for both household income and consumption.

28. Table 3 lists the micro sources used by national experts and the year for the calculation. National experts predominantly relied on household surveys, sometimes combined with administrative records, for 
2008, 2009 or 2010. In most cases national experts used one micro source for (most) income components and one other micro source for (most) consumption components. However, Korea, Mexico and New Zealand used one single source for both income and consumption components. Slovenia linked the micro records from Survey on Income and Living Conditions (SILC) and the Household Budget Survey (HBS) for use in calculation. On the other hand, France made use of five different micro data sets. Information on the micro sources used to breakdown the SNA aggregates in each country is available at http://www.oecd.org/std/WP-STD-2013-4-1.xlsx.

Table 3: Breakdown year and main micro sources used to complete the template, by country

\begin{tabular}{|l|c|l|}
\hline Country & Year & \multicolumn{1}{|c|}{ Micro sources } \\
\hline Australia & $2009-10^{*}$ & $\begin{array}{l}\text { Survey of Income and Housing, Household Wealth and Wealth Distribution, Household } \\
\text { Expenditure Survey }\end{array}$ \\
\hline France & 2003 & $\begin{array}{l}\text { Survey on income and living conditions (EU-SILC), Tax Income Survey (ERFS), } \\
\text { Household Budget Survey, Health Survey, Housing Survey }\end{array}$ \\
\hline Germany & 2008 & Household Budget Survey \\
\hline Israel & 2009 & Household Expenditure Survey \\
\hline Italy & 2008 & Survey on income and living conditions (EU-SILC), Household Budget Survey \\
\hline Japan & 2009 & National Survey on Family Income and Expenditure (NSFIE) \\
\hline Korea & 2009 & Household Income and Expenditure Survey \\
\hline Mexico & 2008 and $2010^{*}$ & Household Income and Expenditure National Survey (ENIGH) \\
\hline Netherlands & 2008 & Income Panel Survey, Household Budget Survey \\
\hline New-Zealand & $2006-07^{*}$ & Household Economic Survey \\
\hline Portugal & $2006 ; 2009^{*}$ & Survey on income and living conditions (EU-SILC), Household Budget Survey \\
\hline Slovenia & 2008 & Survey on income and living conditions (EU-SILC), Household Budget Survey \\
\hline Sweden & 2008 & Household finances, Household Budget Survey \\
\hline Switzerland & 2008 & Survey on income and living conditions (EU-SILC), Household Budget Survey (HABE) \\
\hline Turkey & 2010 & Household Budget Survey \\
\hline United States & 2010 & Current Population Survey (CPS), Consumer Expenditure Survey (CE) \\
\hline
\end{tabular}

* Australia: annual data ending June 2010; Mexico: breakdown performed for both 2008 and 2010; New Zealand: annual data ending June 2007; Portugal: 2006 for consumption components and 2009 for income components.

29. Also, the micro data sources used by national experts contain some shortcomings when compared to the Expert Group's template. The most important of these shortcomings refer to population scope, missing components, and classification issues.

30. Population - Most household surveys exclude a part of the population that is covered in the SNA. People falling outside the scope of micro data sources mainly relate to people without permanent addresses, those living in non-private dwellings (such as prisons, boarding schools, retirement homes, hospitals and nursing homes, religious institutions, hotels, etc.), and those living in overseas territories or in sparsely populated areas. In general, however, the population excluded by micro sources is well below $5 \%$ of the resident population. Some other groups of the population that may be missed by micro sources as well include high income earners in the German household budget survey; households in which all members are aged eighty or more in the Swedish household budget survey; and households whose main source of income sources arise from activities in farm, forestry and fishery in the Korean Household Income and Expenditure Survey. Also, the definition of the household in the micro source may not fit with the one defined in the template (see II.A).

31. Missing components - Micro sources usually do not provide information for a number of items that are part of the national accounts definition of income and consumption. For instance, this is the case of employers imputed social contributions and Financial Intermediation Services Indirectly Measured (FISIM) in all countries; of actual social contributions to (and benefits from) employer related insurance schemes, property income attributed to insurance policy holders, Social Transfers in Kind in most countries; and of imputed rentals for owners-occupied housing, own-account production of goods, wages and salaries in kind, interest paid on consumption loans, non-life insurance premiums and claims and 
expenditures on games of chance, in several countries. These components can be missing in micro sources due to both conceptual and practical reasons. For example, compilers of micro statistics may consider that some national accounts components that are useful to describe the economy as a whole are not relevant when the focus is the economic behaviour of households. As a consequence, they may fail to distinguish these components from micro sources (e.g., FISIM). On the other hand, some national accounts components may be missing from micro sources for practical reasons, in particular because the information is difficult to collect/impute.

32. Classification: Micro sources may follow a different classification than the one included in the template. For instance, wages and salaries paid while on sick or maternity leave are often recorded as wages and salaries in micro sources, but as social benefits in national accounts. Also, the income received by a sleeping or silent partner ${ }^{8}$ participating in an unincorporated enterprise is typically considered as property income by micro sources but as mixed income in national accounts.

33. Other divergences between micro sources and national accounts reflect differences in how they value transactions (e.g. imputed rental for owner-occupied housing) and in statistical adjustments applied (e.g. for non-response, sampling error, underreporting, time recording). Expert Group members investigated the main divergences between micro and macro sources; the main results of this analysis are described in Fesseau M., Wolff F. and Mattonetti M-L. (2013).

\section{Methodology used to distribute SNA totals among different groups of households}

34. The estimation of data by household groups consisted of applying the most relevant distributional information available to the relevant national accounts totals for each of the components listed in the template. The process followed four steps (Box 2), which are described in this sub-section.

\section{Box 2: The breakdown process in four steps}

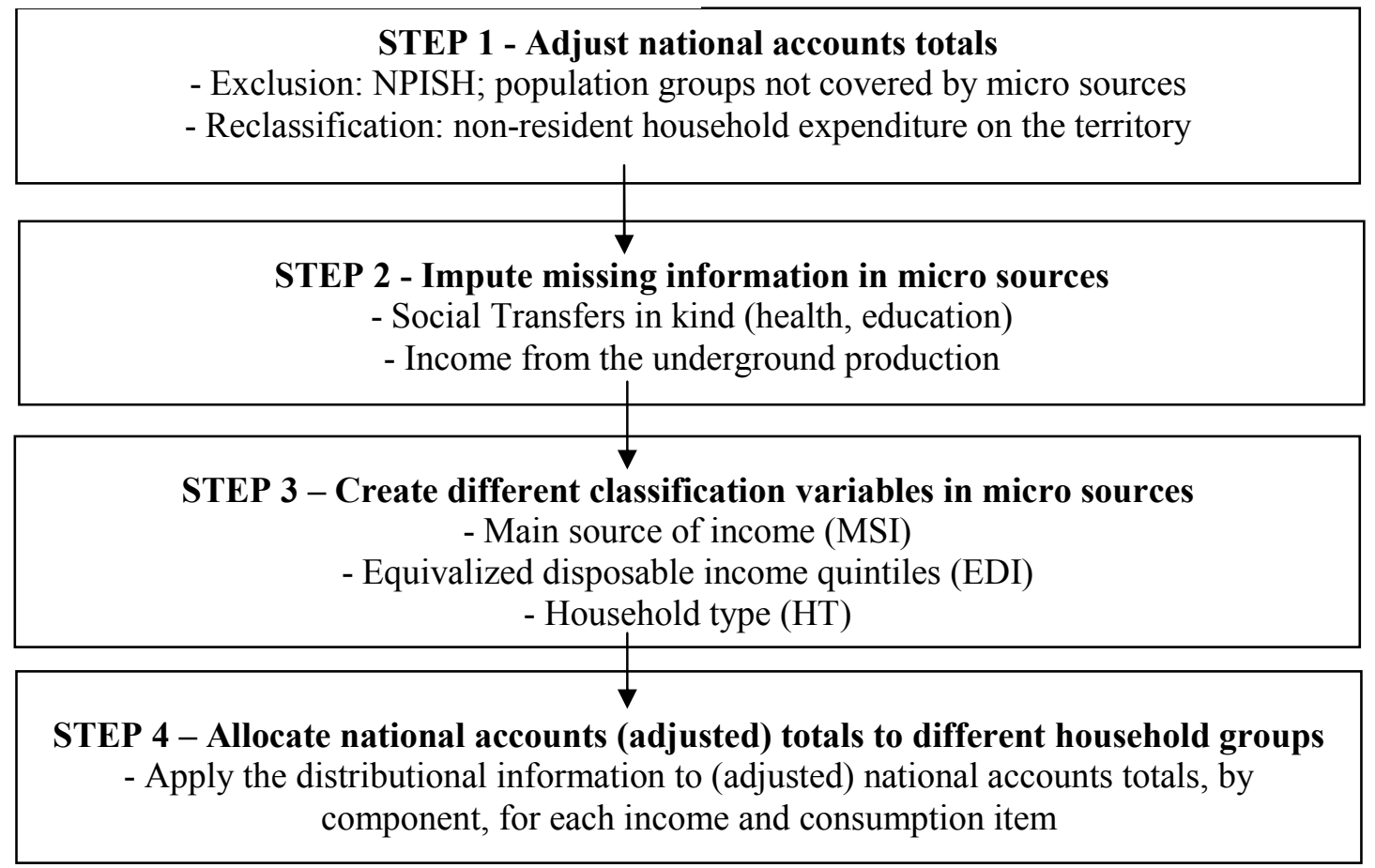

Sleeping or silent partners are partners who do not work in the enterprises. 


\section{Step 1: Adjust national accounts totals}

35. In the first step, national accounts totals were adjusted, when relevant, by excluding the income and the expenditures of NPISH and by subtracting the expenditures of non-resident household on the territory from the detailed consumption expenditures. National accounts totals were also adjusted, when relevant, to assure consistency with the available distributional information, by excluding the population not covered by the micro sources.

Non-Profit Institutions Serving Households

36. Experts from Australia, Germany, Korea and Switzerland, where the household sector accounts include NPISH made rough estimates to exclude them from national accounts totals. Australia and Korea could make use of information available such as NPISH satellite accounts produced in the past and/or administrative data providing information on transfers from general government and public non-financial corporations. In the absence of information on the major income items for NPISH, experts from Switzerland made use of estimates from other countries'. The components for which national accounts totals were adjusted for NPISH depend on the country. Table 4 shows that NPISH do not have a significant impact on the relevant national accounts totals, with the exception of other current transfers ${ }^{10}$.

Table 4: Impact of NPISH adjustment on national accounts totals

NPISH total as a percentage of the national accounts total that include NPISH and households

\begin{tabular}{|l|r|r|r|r|}
\cline { 2 - 4 } \multicolumn{1}{c|}{} & $\begin{array}{c}\text { Australia } \\
\mathbf{2 0 0 9 - 1 0}\end{array}$ & $\begin{array}{c}\text { Germany } \\
\mathbf{2 0 0 8}\end{array}$ & $\begin{array}{c}\text { Korea } \\
\mathbf{2 0 0 9}\end{array}$ & \multicolumn{1}{c|}{$\begin{array}{c}\text { Switzerland } \\
\mathbf{2 0 0 8}\end{array}$} \\
\hline Operating surplus* received & & & $3 \%$ & $2 \%$ \\
\hline Property income ${ }^{* *}$ received & $2 \%$ & $\mathbf{4} \%$ & $2 \%$ & $2 \%$ \\
\hline Property income ${ }^{* *}$ paid & & $4 \%$ & $1 \%$ & $1 \%$ \\
\hline Other current transfers received minus paid & & & $62 \%$ & $-477 \%$ \\
\hline
\end{tabular}

* In Switzerland the ratio is measured on the total operating surplus and mixed income since the two items are not separated in the compilation process.

** Excluding property income attributed to insurance policy holders and before allocating FISIM.

Expenditures of non-resident households on the territory ${ }^{11}$

37. National accounts expenditure totals for detailed components were adjusted by subtracting the expenditures of non-resident households when relevant (for France, Israel, Italy, Korea, Mexico, Netherlands, Portugal, Sweden, Slovenia, Turkey and the United States). To do so, the total expenditures of non-resident households on the territory, as available in the SNA, have been broken down by detailed category of expenditures using information from tourism satellite accounts, balance of payments, surveys on foreign tourism and credit card information.

38. Figure 1 shows the impact on the national accounts total for expenditure components most affected by this adjustment (i.e. components for which more than three countries show an impact, higher than $5 \%$ of the relevant total). In all countries, restaurant and hotel expenditures are significantly reduced by the adjustment, with a reduction ranging from $8 \%$ in Turkey and Korea to $29 \%$ in Portugal.

9 This method has been developed as part of the Eurostat a-minima exercise. More detail on the method is provided in Eurostat (forthcoming 2013).

The net total of "other current transfers" published in Switzerland for the aggregated sector combining household and NPISH is negative. The estimates measured strictly on households show, however, that households are mostly paying those transfers whereas NPISH mostly receive transfers.

In the Expert Group template, the expenditure of resident households made abroad are isolated in a separate item. 
Expenditures on transport services are also reduced in most countries, with a reduction of close to $50 \%$ in France and in the Netherlands.

Figure 1: Impact of the adjustment for expenditures by non-resident households on national accounts totals, by component*

Non-resident expenditure total as a percentage of non resident and resident expenditure on the territory

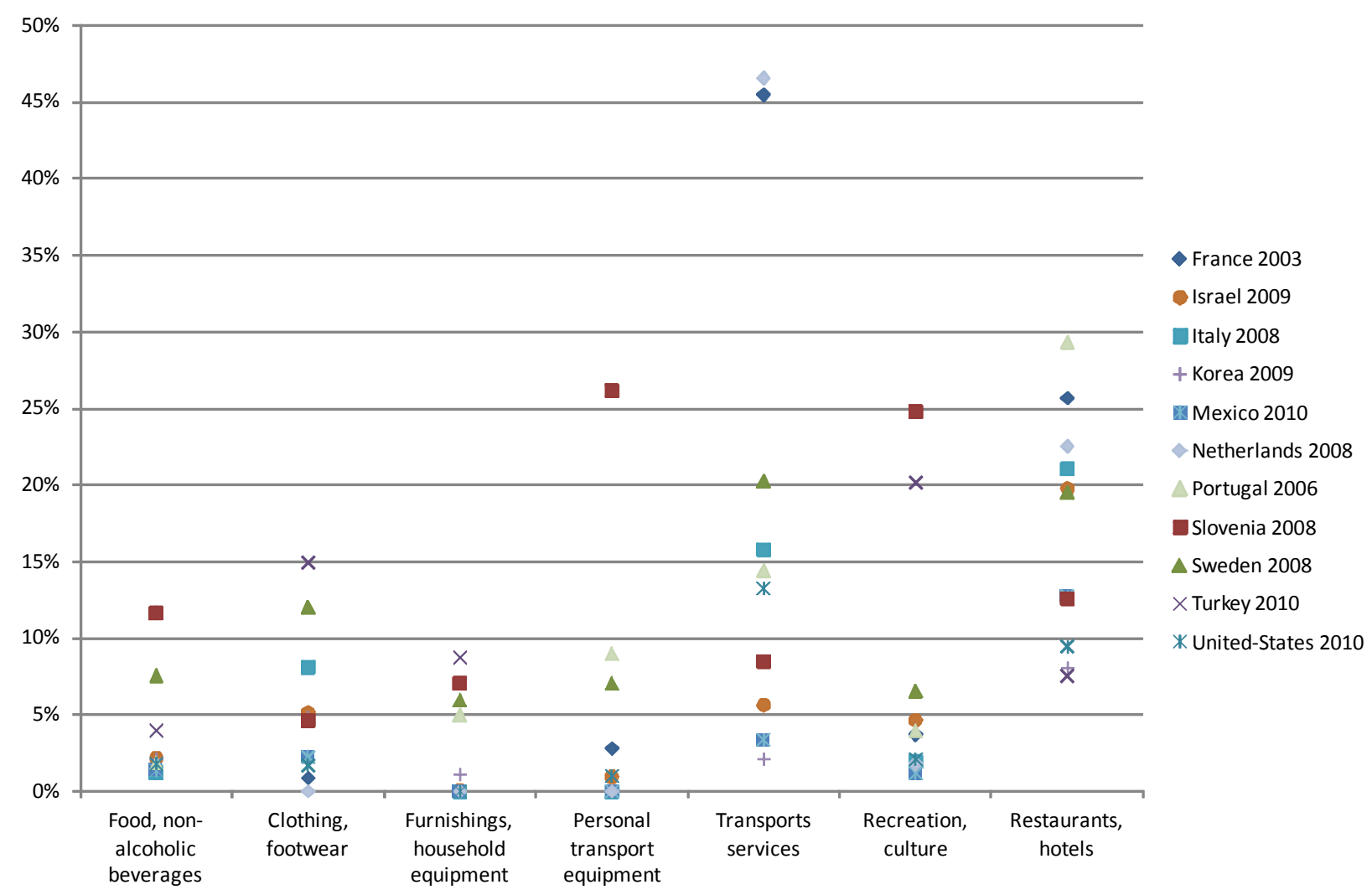

* Only the expenditures components most affected by the adjustment are shown.

39. Differences across countries in the impact of the adjustment may be explained by differences in the importance of non-resident households' expenditures on the territory and/or in the composition of nonresident household expenditure. The share of non-resident households in total domestic expenditure ranks from 2\% in Korea, Mexico and the United States to 9\% in Slovenia. In Turkey non-resident household spent on average $10 \%$ of their total expenditure on food as compared to $20 \%$ in Sweden, although the share of non-resident households in the total domestic expenditure is similar (5\%).

Population not covered by micro sources

40. People falling outside the scope of micro data sources mainly relate to people without a permanent address, those living in non-private dwellings (such as prisons, boarding schools, retirement homes, hospitals and nursing homes, religious institutions, hotels, etc.), and those living in territories overseas or in sparsely populated areas. The Expert Group did not reach a full consensus on the importance of excluding these population groups from the national accounts totals prior to the calculation, because of their small size and because of a lack of adequate data to make the adjustment. One argument in favor of adjusting national accounts totals is that the population groups outside the scope of micro sources may have a significant impact on some specific income and consumption components (e.g. social protection spending and Social Transfers in Kind related to health for people living in retirement homes). 
41. Australia, France, Israel, Italy, Korea, Slovenia, Sweden, Switzerland and the United States adjusted their national accounts totals by subtracting the income and expenditures flows attributed to these people not covered by micro sources ${ }^{12}$. Adjustments were applied, to the extent possible, by population group and for specific income and consumption components, since these population groups targeted are expected to have income and consumption patterns that differ significantly from those of the population covered by micro sources. In practice, most national experts used one or a combination of three methods:

- Direct estimates for specific population groups: e.g. regional accounts for people living in overseas territories for France, data on the income of people who are homeless or living in residential treatment centres for addicts in Sweden, information on government, civilian and military staff stationed abroad and private workers abroad for one year or less in the United States;

- Demographic information from Population and Housing Censuses on the number of people by detailed groups multiplied by a per capita estimate from micro sources; For instance, the number of people aged 75 and over living in retirement homes was multiplied by the average social benefits per capita received by people 75 years old as reported in the household income survey. The assumption underlying this approach is that, for a given socio-demographic group, average income and average consumption expenditures for people covered by micro sources are similar to those for people not covered by micro source.

- Information on the share of groups in question in total population. For a given group, such as people living in retirement homes, an estimate of the share of this group in total population was subtracted from the national accounts totals for each income and consumption components. The underlying assumption is that average income and average consumption expenditures are similar for people covered by micro sources and those not covered by micro source.

42. Overall, the impact of these adjustments was below 5\% of national accounts totals, and mainly relate to a limited number of quite specific components. The components most frequently impacted were other current transfers received net of transfers paid, expenditures on miscellaneous goods and services (which include social protection spending), and Social Transfers in Kind received. STiK for health were reduced by $28 \%$ in the United States, while other STiK which exclude government spending on health and education were reduced by $27 \%$ in France.

43. In the case of France, Israel and Korea, however, the adjustment for the population not covered by micro sources impacted a high number of income and consumption items. For Israel this may be explained by the methodology applied ${ }^{13}$. For Korea, the high impact of the adjustment (which reduced income from own account production by $32 \%$ ) may be explained by the fact that a larger part of the population is not covered by the micro source.

44. A specific issue regarding the population falling outside the scope of the micro sources is related to the income and expenditure of persons who died during the year, which in some countries are not captured in micro sources. Indeed, some household surveys collect income data referring to the previous calendar year; it follows that persons who died in the previous year, are by definition not in the sample. The factor may be significant for some of the income components, such as Social Transfers in Kind. In the

12 The adjustment is not relevant in Portugal for income and consumption components since the micro side has the same scope as the macro data. Indeed, the used surveys are calibrated to total population. The adjustment is not relevant in the Netherlands for income components because the used micro sources cover all residents. In Japan, Mexico, Turkey, New Zealand and in the Netherlands (limited to the consumption components), experts decided not to adjust national accounts totals because of the population small size and of lack of data.

Israel attributed for each income and consumption component, the difference between the household survey total and the national accounts total to people falling outside the scope of micro source. 
United States, around 25\% of Medicare and Medicaid expenditures went to those in the last year of life (Clinton P. Mc Cully (2012)). The significance of this factor may differ across countries depending on the micro sources used. SNA totals for the United States ${ }^{14}$ and Italy were adjusted for this factor.

\section{Step 2: Impute missing information at the micro level}

45. For a number of components for which no distributional information was available in micro sources, national experts made imputations at the micro level. This sub-section describes the imputation applied to Social Transfers in Kind for health and education, and income from underground production.

\section{Social Transfers in Kind (STiK) for healthcare}

46. In the Expert Group template the STiK component includes goods and services provided by general government to individuals to cover health care needs. These goods and services are provided for free or at subsidized prices; they can be supplied directly by general government or can be purchased by households themselves and later reimbursed by government. In most OECD countries, national accounts compilers estimate this income component using administrative sources (see Fesseau M., Wolff F. and Mattonetti M-L. (2013)). However, very few countries have information on this type of government spending at the micro level, e.g. showing the cost of hospital services or medicines reimbursed to each individual household.

47. Several studies discuss the issue of how to allocate health government spending, and other types of Social Transfers in Kind, among individuals and households (for instance, see Verbist G., Forster M. and Vaalavuo M. (2012)). The two main approaches for allocating the value of STiK covering health care needs are:

- The actual consumption approach which is based on data on the effective use of health care services by individuals. Based on this approach, every individual who actually use health care services receive a public benefit;

- The insurance approach which allocates to each individual the average health care cost of a person with the same socio-demographic profile (age, sex, etc...). In this approach, every individual is assumed to receive a public benefit determined by the average public spending of his/her group, irrespective of whether or not they have used these services.

48. National experts relied on the insurance approach, for both practical and conceptual reasons. The significant impact of this component on the results required harmonizing the imputation method across countries; further, most countries have no information to implement the actual use approach. Overall, twelve countries (Australia, France, Israel, Italy, Japan, Korea, Mexico, the Netherlands, New Zealand, Sweden, Slovenia, the United States), imputed STiK using an insurance approach based on different sources to estimate the average health care cost for each socio-demographic group. The criteria used to define the socio-demographic groups may differ across countries. Age is a common criterion used in all countries but other individual characteristics were taken into account by some experts such as gender, region, deprivation and health status (disabled or in long-term care). Estimates for Sweden were based on both the insurance and the actual use approach. The latter was performed by combining micro data per individual and costs for certain activities. For example, information on type of treatment and time in

14 In the United States mortality rates by population group were used to estimate income for decedents using micro data. Also, administrative sources on Medicare and Medicaid expenditures were used for health Social Transfers in Kind. Italy only adjusted the STiK national account component by using information on the number of people who died and information on per capita average public spending by age group. 
treatment by individuals was combined with information on the cost of one day of treatment for a certain activity and on total costs at an aggregated level (annual accounts for municipalities and county councils).

49. The distribution of STiK for health resulting from these imputations differs across countries. In most of the countries, STiK appear to be targeted on the poorest households (Table 5); this is especially the case in the United States, where $30 \%$ of the total STiK for health is received by the $20 \%$ of the poorest households. To a certain extent the profile of STiK is increasing with income in France. In New Zealand and the Netherlands, STIK for health are relatively large for households belonging to the middle of the distribution. Differences in the distribution of STiK across quintiles might be explained by cross country differences in the household composition of the different quintiles (see step 3), in the types of population targeted by STiK, and/or by differences in the content of what is classified as STiK by national accountants.

50. In all countries, the relative income gain due to STiK for health decreases with income quintiles (Table 6). In the Netherlands, however, the rise in household income is lower for households belonging to the first quintile than for those in the second quintile.

Table 5: Distribution of STiK on health across income quintiles*

\begin{tabular}{|l|c|c|c|c|c|c|}
\cline { 2 - 6 } \multicolumn{1}{c|}{} & Q1 & Q2 & Q3 & Q4 & Q5 & Total \\
\hline Australia 2011-12 & $21 \%$ & $22 \%$ & $20 \%$ & $19 \%$ & $18 \%$ & $\mathbf{1 0 0} \%$ \\
\hline France 2003 & $19 \%$ & $19 \%$ & $20 \%$ & $20 \%$ & $22 \%$ & $\mathbf{1 0 0} \%$ \\
\hline Israel 2009 & $22 \%$ & $21 \%$ & $20 \%$ & $19 \%$ & $18 \%$ & $\mathbf{1 0 0} \%$ \\
\hline Italy 2008 & $20 \%$ & $22 \%$ & $21 \%$ & $19 \%$ & $19 \%$ & $\mathbf{1 0 0} \%$ \\
\hline Korea 2009 & $24 \%$ & $21 \%$ & $19 \%$ & $19 \%$ & $17 \%$ & $\mathbf{1 0 0} \%$ \\
\hline Mexico 2010 & $22 \%$ & $21 \%$ & $21 \%$ & $19 \%$ & $18 \%$ & $\mathbf{1 0 0} \%$ \\
\hline Netherlands 2008 & $11 \%$ & $24 \%$ & $24 \%$ & $24 \%$ & $17 \%$ & $\mathbf{1 0 0} \%$ \\
\hline New Zealand 2006-07 & $19 \%$ & $23 \%$ & $22 \%$ & $18 \%$ & $18 \%$ & $\mathbf{1 0 0} \%$ \\
\hline Slovenia 2008 & $22 \%$ & $20 \%$ & $19 \%$ & $19 \%$ & $19 \%$ & $\mathbf{1 0 0} \%$ \\
\hline Sweden 2008 & $16 \%$ & $23 \%$ & $21 \%$ & $19 \%$ & $21 \%$ & $\mathbf{1 0 0} \%$ \\
\hline Sweden 2008, Actual method & $18 \%$ & $24 \%$ & $21 \%$ & $19 \%$ & $18 \%$ & $\mathbf{1 0 0 \%}$ \\
\hline United States 2010 & $30 \%$ & $25 \%$ & $18 \%$ & $14 \%$ & $14 \%$ & $\mathbf{1 0 0} \%$ \\
\hline
\end{tabular}

* Income quintiles correspond to the Expert Group grouping definition (see Annex 2).

Table 6: STiK on health as a percentage of household disposable income across income quintiles*

\begin{tabular}{|l|c|c|c|c|c|c|}
\cline { 2 - 6 } \multicolumn{1}{c|}{} & $\mathbf{Q 1}$ & $\mathbf{Q 2}$ & $\mathbf{Q 3}$ & $\mathbf{Q 4}$ & $\mathbf{Q 5}$ & Total \\
\hline Australia 2009-10 & $21 \%$ & $17 \%$ & $12 \%$ & $8 \%$ & $5 \%$ & $\mathbf{1 0 \%}$ \\
\hline France 2003 & $24 \%$ & $15 \%$ & $11 \%$ & $9 \%$ & $5 \%$ & $\mathbf{1 0 \%}$ \\
\hline Italy 2008 & $27 \%$ & $18 \%$ & $13 \%$ & $9 \%$ & $4 \%$ & $\mathbf{1 0 \%}$ \\
\hline Korea 2009 & $21 \%$ & $9 \%$ & $6 \%$ & $4 \%$ & $3 \%$ & $\mathbf{6 \%}$ \\
\hline Mexico 2010 & $20 \%$ & $10 \%$ & $7 \%$ & $4 \%$ & $1 \%$ & $\mathbf{3 \%}$ \\
\hline Netherlands 2008 & $18 \%$ & $24 \%$ & $18 \%$ & $14 \%$ & $6 \%$ & $\mathbf{1 4 \%}$ \\
\hline New Zealand 2006-07 & $31 \%$ & $23 \%$ & $14 \%$ & $9 \%$ & $5 \%$ & $\mathbf{1 1 \%}$ \\
\hline Slovenia 2008 & $22 \%$ & $12 \%$ & $9 \%$ & $7 \%$ & $4 \%$ & $\mathbf{8 \%}$ \\
\hline Sweden 2008 & $35 \%$ & $27 \%$ & $15 \%$ & $10 \%$ & $7 \%$ & $\mathbf{1 3 \%}$ \\
\hline Sweden 2008, Actual method & $39 \%$ & $29 \%$ & $16 \%$ & $10 \%$ & $6 \%$ & $\mathbf{1 3 \%}$ \\
\hline United States 2010 & $50 \%$ & $20 \%$ & $9 \%$ & $5 \%$ & $2 \%$ & $\mathbf{8 \%}$ \\
\hline
\end{tabular}

* Income quintiles correspond to the Expert Group grouping definition (see Annex 2). 
Social Transfers in Kind for education

51. To allocate government spending on education, the method applied by national experts consisted of allocating to each student a public benefit determined by the average public spending of his/her level of education. Following this approach, only those individuals who are identified as studying in the micro source receive STiK on education. In most countries, due to data availability, the method applied by national experts does not take into account whether households use public education services or private education services. This may be a significant issue for countries where higher-income households mainly opt for private education.

52. Twelve countries (Australia, France, Israel, Italy, Japan, Korea, Mexico, the Netherlands, New Zealand, Sweden, Slovenia, the United States) imputed Social Transfers in Kind for education. The distribution of STiK for education resulting from these imputations differs across countries (Table 7). As in the case of STiK for health, differences in the distribution of STiK for education across quintiles might reflect cross-country differences in the household composition of the quintiles (see step 3), in the types of population targeted by STiK, and/or in the content of what is classified as STIK by national accountants.

Table 7: Distribution of STiK on education across income quintiles*

\begin{tabular}{|l|c|c|c|c|c|c|}
\multicolumn{1}{c|}{} & $\mathbf{Q 1}$ & $\mathbf{Q 2}$ & $\mathbf{Q 3}$ & $\mathbf{Q 4}$ & $\mathbf{Q 5}$ & Total \\
\hline Australia 2009-10 & $25 \%$ & $23 \%$ & $22 \%$ & $17 \%$ & $14 \%$ & $\mathbf{1 0 0} \%$ \\
\hline France 2003 & $28 \%$ & $20 \%$ & $18 \%$ & $18 \%$ & $15 \%$ & $\mathbf{1 0 0} \%$ \\
\hline Israel 2009 & $28 \%$ & $20 \%$ & $18 \%$ & $19 \%$ & $15 \%$ & $\mathbf{1 0 0} \%$ \\
\hline Italy 2008 & $23 \%$ & $21 \%$ & $19 \%$ & $19 \%$ & $18 \%$ & $\mathbf{1 0 0} \%$ \\
\hline Korea 2009 & $11 \%$ & $22 \%$ & $26 \%$ & $23 \%$ & $18 \%$ & $\mathbf{1 0 0} \%$ \\
\hline Mexico 2010 & $24 \%$ & $22 \%$ & $20 \%$ & $19 \%$ & $15 \%$ & $\mathbf{1 0 0} \%$ \\
\hline Netherlands 2008 & $18 \%$ & $35 \%$ & $26 \%$ & $9 \%$ & $13 \%$ & $\mathbf{1 0 0} \%$ \\
\hline New Zealand 2006-07 & $25 \%$ & $19 \%$ & $24 \%$ & $19 \%$ & $13 \%$ & $\mathbf{1 0 0 \%}$ \\
\hline Slovenia 2008 & $21 \%$ & $23 \%$ & $21 \%$ & $18 \%$ & $17 \%$ & $\mathbf{1 0 0 \%}$ \\
\hline Sweden 2008 & $20 \%$ & $16 \%$ & $25 \%$ & $23 \%$ & $17 \%$ & $\mathbf{1 0 0 \%}$ \\
\hline United States 2010 & $19 \%$ & $26 \%$ & $23 \%$ & $19 \%$ & $14 \%$ & $\mathbf{1 0 0 \%}$ \\
\hline
\end{tabular}

* Income quintiles correspond to the Expert Group grouping definition (see Annex 2).

Income from the underground production

53. In the national accounts compilation process, adjustments are made to correct for underground production, i.e. the deliberate concealment of legal activities to avoid tax payments by registered and unregistered units. The nature of the national accounts adjustment, and the way it is compiled, are country specific. Depending on country practices, the adjustment may affect several components of the household accounts, in particular compensation of employees, mixed income and property income received.

54. The Expert Group template separates the adjustment for underground production that affects mixed income as a specific component. Six countries (Australia, France, Italy, the Netherlands, Sweden and the United States) worked on this specific item. Among these countries the relevance of the underground production adjustment varies, from $1 \%$ of the disposable income in Australia to $5 \%$ in the United States and 9\% in Italy.

55. Italy applied a refined method ${ }^{15}$ to allocate the "off-the-record" production adjustment to individual households based on the method used to estimate this adjustment in the SNA. "Off-the-record"

15 The method applied is fully described in Coli A. and Tartamella F. (2012). 
production, i.e. income from production by self-employed households that is not reported, is calculated as the difference between the income declared by the self-employed person and the amount that he would be expected to earn if he was an employee working in the same economic sector, in a firm of similar size and working a similar number of hours in a similar type of job.

56. In the case of Italy, the adjustment based on the above method is concentrated on the top of the distribution, with $59 \%$ of the total adjustment received by the $20 \%$ richest households. The share of mixed income received by the top quintile, however, is reduced by three points, benefiting households belonging to the fourth quintile (Table 8). Imputation for the underground production hence slightly increases inequality by increasing significantly the income received by the richest households.

Table 8: Impact of underground production on mixed income and disposable income across quintiles - Illustration on Italy, 2008* Distribution of the National Accounts totals

\begin{tabular}{|l|c|c|c|c|c|c|}
\cline { 2 - 6 } \multicolumn{1}{c|}{} & $\mathbf{Q 1}$ & $\mathbf{Q 2}$ & $\mathbf{Q 3}$ & $\mathbf{Q 4}$ & $\mathbf{Q 5}$ & Total \\
\hline Adjustment & $2 \%$ & $6 \%$ & $10 \%$ & $24 \%$ & $59 \%$ & $\mathbf{1 0 0} \%$ \\
\hline Mixed income excluding adjustment & $3 \%$ & $5 \%$ & $8 \%$ & $15 \%$ & $69 \%$ & $\mathbf{1 0 0 \%}$ \\
\hline Mixed income including adjustment & $2 \%$ & $5 \%$ & $8 \%$ & $18 \%$ & $66 \%$ & $\mathbf{1 0 0} \%$ \\
\hline Disposable income excluding adjustment & $8 \%$ & $13 \%$ & $17 \%$ & $22 \%$ & $41 \%$ & $\mathbf{1 0 0} \%$ \\
\hline
\end{tabular}

* Income quintiles correspond to the Expert Group grouping definition (see Annex 2).

\section{Step 3: Create different classification variables at the micro level}

57. Within each micro source, three variables were created, corresponding to the three household groupings used in this study, namely i) Equivalized household disposable income quintile (EDI); ii) main source of income (MSI); and iii) household type (HT). The variables are used to identify to which household group each household belongs, for each of the three classifications. These variables are created by making use of the information available at the individual and at the household level in micro sources.

Household groups characteristics

58. There are similarities and differences across countries in the share of each household group in total households and in the socio-demographic characteristics of each household group. Information on the number of households and number of consumption units per household groups by country is available at http://www.oecd.org/std/WP-STD-2013-4-2.xlsx. Information on the sources of the demographic data is provided at the same link.

59. Main source of income - Overall, households whose main source of income is either wages and salaries or transfers are the two most important groups. Conversely, households whose main income source is either property income or income from self-employment represent a much lower share of the total (Figure 2). However, some countries are outliers in this respect: in Italy households whose main source of income is wages and salaries represent less than $50 \%$ of total households; in Italy, Mexico, Turkey and Korea, households mainly relying on self-employment income represent more than $15 \%$ of all households; while in Israel, households mainly relying on property income account for $25 \%$ of total households.

60. Equivalized Income quintiles - By definition each quintile represent $20 \%$ of total households in each country. The composition of each group may however show differences across countries. When looking at the average number of consumption unit per quintile, no clear pattern emerges. There are countries where the poorest households show a lower household size in consumption units compared to the other quintiles (e.g. Germany, Korea and Slovenia) while they present a higher size in others (e.g. Mexico, Figure 3). 
Figure 2 - Structure of households by main source of income

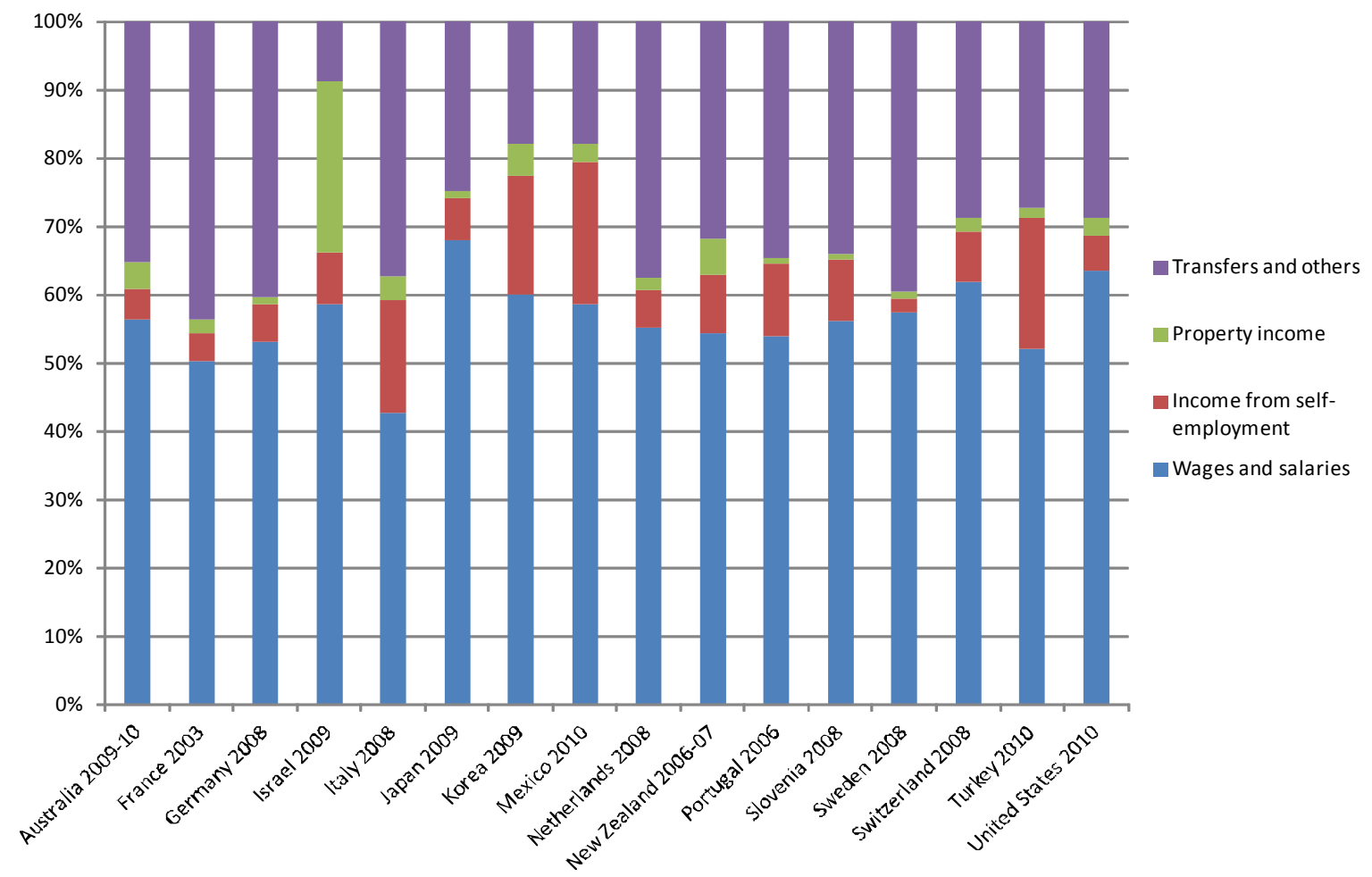

Figure 3 - Number of consumption units across households by equivalized disposable income

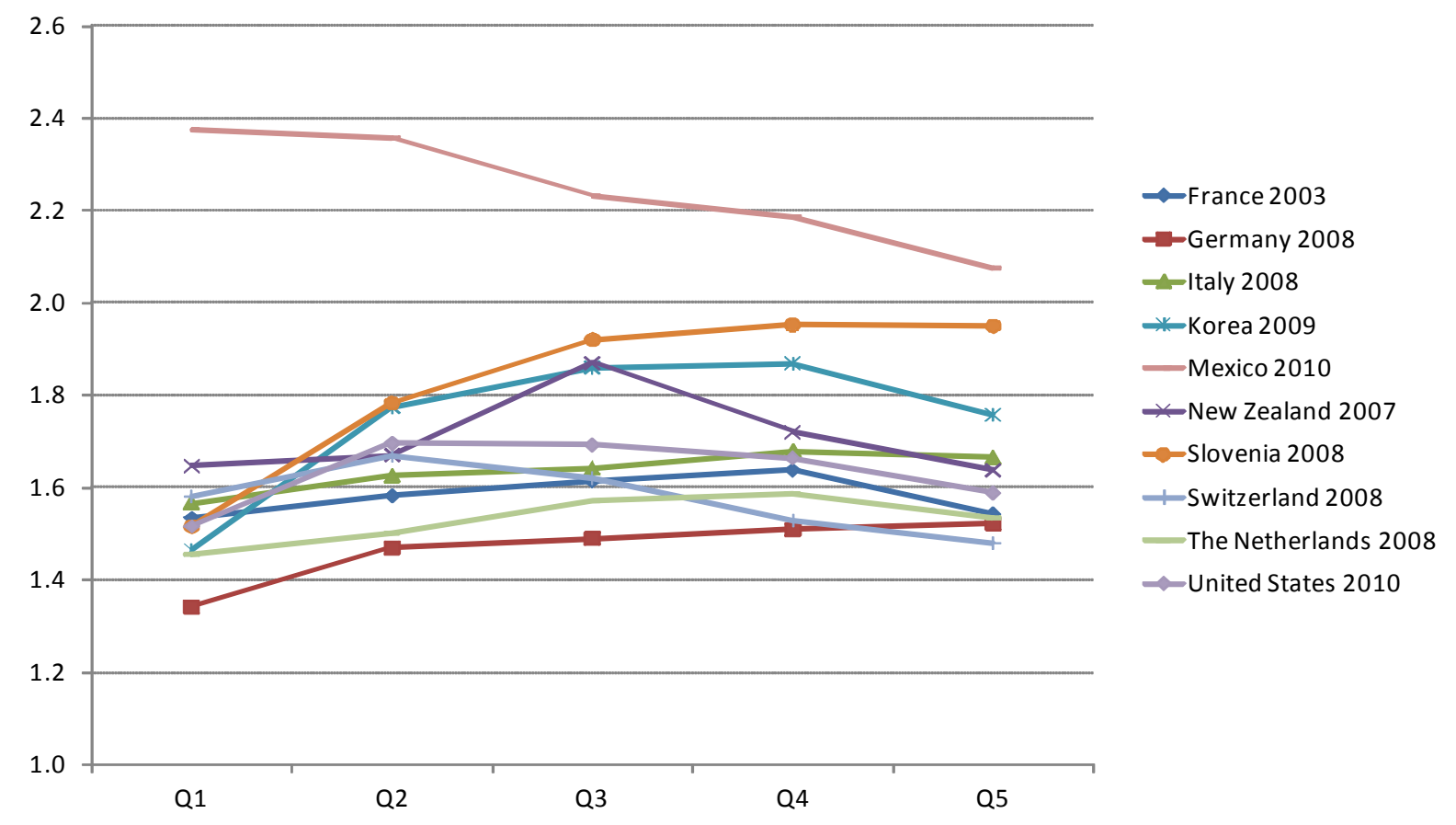

61. Household type - There are significant differences in the share of the households groups in the total (Figure 4). Households composed of one single adult under 65 years old represents 3\% of all 
households in Israel and Turkey, but 25\% in the Netherlands and 35\% in Sweden. The category "other households" which includes households with more than two adults represents $1 \%$ of total households in Sweden as opposed to $29 \%$ in Japan and $39 \%$ in Turkey.

\section{Figure 4: Structure of the households by household type}

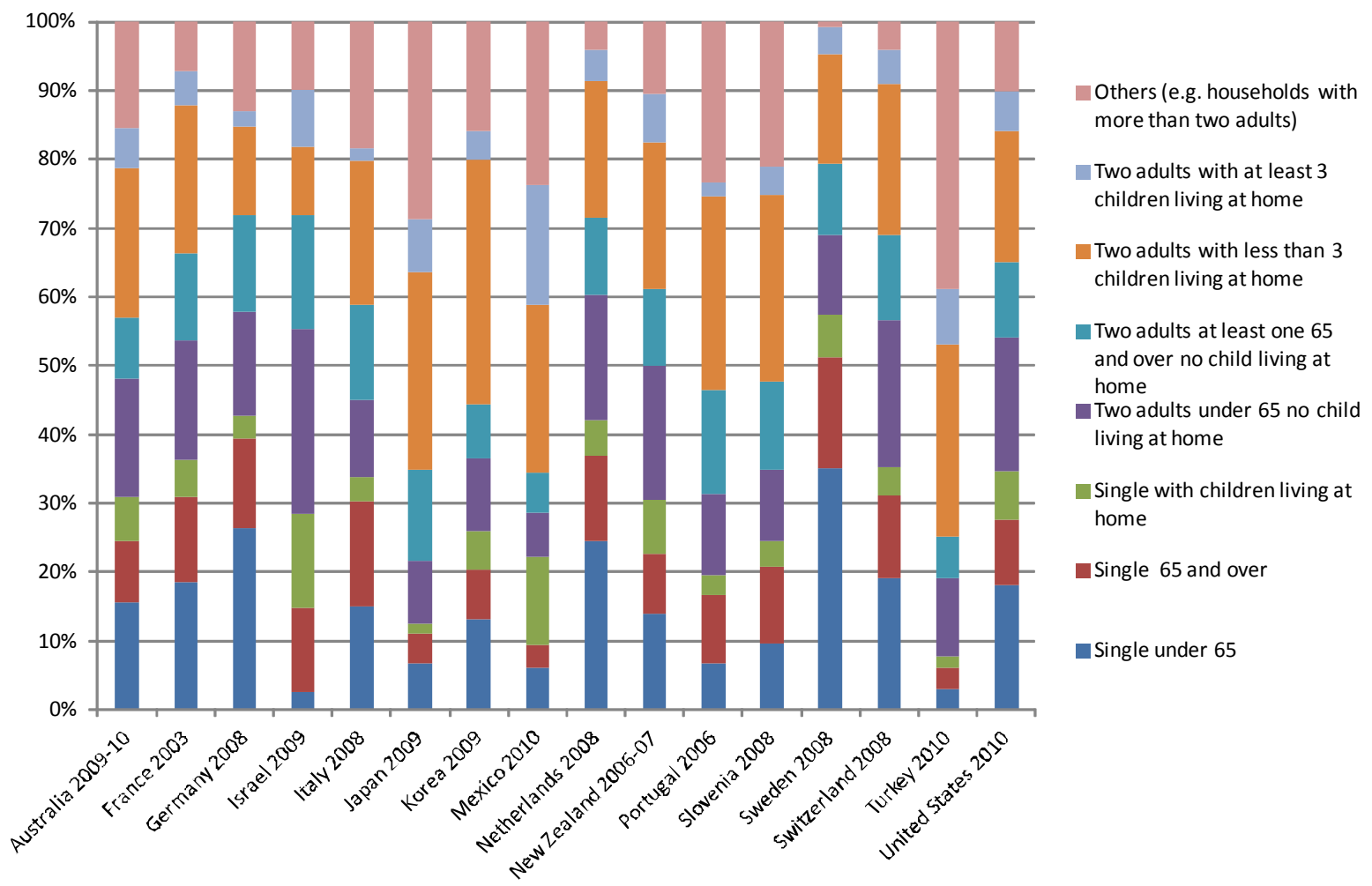

62. Due to data limitation some countries departed from the Expert Group definitions, which may create divergences across countries. The main departures are related to i) the absence of benchmark of income micro variables to national accounts totals prior to the classification of households in groups in Germany, Israel, Portugal, Sweden and Turkey; ii) the income definition used in France (which include imputed rentals) and Switzerland (which exclude interest paid and include some national accounts concepts e.g. employers' imputed social contributions) for the income groups; iii) the definition of children living at home in Australia (offspring not identified); iv) the way consumption units are calculated in the United States (the 18 cutoff has been used to define a child instead of the 14 age). Also, the definition of households in micro sources is not fully harmonized across countries (see information available at http://www.oecd.org/std/WP-STD-2013-4-1.xlsx).

\section{Step 4: allocate national accounts adjusted totals to different household groups}

63. For each component of the Expert Group's template, the national account adjusted totals were distributed between household groups using the most relevant distributional information. This allocation was computed separately for each of the three household group classifications.

\section{Calculation}

64. Three pieces of information were used to allocate the adjusted national account totals to different household groups: i) the adjusted national accounts total; ii) the average income/expenditure per household for each household group and, iii) the number of households for each household group. 
Notation:

$\mathrm{X}$ : income/consumption component

$i=\{1, \ldots, I\}$ identifies the household groups

e.g, $i=\{\mathbf{1}, 2,3,4,5\}$ for the classification by quintile of equivalized disposable income

$n_{i}$ : total number of households in household group $i$

$N$ : total number of households, with $N=\sum_{i=1}^{I} n_{i}$

$\bar{x}_{i}:$ the average per household of group $i$, for the component $X$

e.g. the average wages and salaries received by the $20 \%$ poorest households

$X^{\text {NA_adj: }}$ : the national accounts adjusted total for $X$

65. The allocation of the adjusted national accounts total in subtotals is performed component by component, as follows:

- For each household group, a micro subtotal was calculated by multiplying the total number of households in the group and the corresponding average income/expenditure value per household:

$$
X_{i}=n_{i} \times \bar{x}_{i}
$$

- The micro total across all households was then computed as the sum of the micro subtotals:

$$
X=\sum_{i=1}^{I} X_{i}
$$

- An adjustment coefficient was obtained by dividing the adjusted national accounts total and the micro total across all households:

$$
\alpha=\frac{X^{N A_{-} a d j}}{X}
$$

- Finally, each of the micro subtotals was adjusted to match the adjusted national accounts total:

$$
X_{i}^{N A_{-} a d j}=\alpha \times X_{i} \text {, with } \sum_{i=1}^{l} X_{i}^{N A_{-} a d j}=X^{N A_{-} a d j}
$$

66. Due to data limitation some countries departed from the Expert Group list of income and consumption components to be broken down. In particular, some countries did not study STiK (Germany, Portugal and Switzerland). Also, the estimates compiled by some experts exclude FISIM (Germany, France and Portugal) or resident expenditures abroad (France, Israel and Portugal).

Distributional information

67. The type of information used as averaged per household $\left(\bar{x}_{i}\right)$ depends on what is available in micro source. Three methods were applied:

- Method A, applied when information on the distribution of the national accounts component $X$ is available in the micro source. For these components, the distributional information available in micro data source is used for the calculation;

- Method B, applied when no information on the distribution of the national accounts component $X$ is directly available in the micro source but where indirect information could be used. Two variants were applied for method B depending on whether the indirect information used was available in the micro source (proxy) or imputed by national experts (imputation, step 2). In the former case, the distributional information available for an income/expenditure component $\mathrm{Y}$ is used to distribute $\mathrm{X}$, assuming that $\mathrm{Y}$ and $\mathrm{X}$ are distributed in the same way. In the latter case, imputation of the distribution for the component $\mathrm{X}$ is performed at the micro level based on socio-demographic 
information available at the individual and at the household levels. In both cases the assumptions made to allocate totals can impact on the overall final distribution.

- Method C, applied when no information on the distribution was directly available, no imputation was performed and no proxy was available. For these income/expenditure components, the national accounts totals were distributed among all households in such a way that the inclusion or exclusion of these components did not impact on the aggregate disparity indicators. This implies that the income/consumption components considered was assumed to be distributed in the same way as the components for which method A and B were applied.

68. Overall, method A was applied to most of the components of consumption expenditure and to the income components of wages and salaries received, social benefits received, and current taxes on income paid. In the case of method A, the coefficient $\alpha$ represents the gap between the micro and macro totals for the same component. These coefficients differ across countries and income/expenditure components. In the case of household income, these coefficients are highest for property income paid, property income received, and mixed income (Table 9); in the case of consumption expenditure they are highest for hospital services, alcoholic beverages and tobacco (Table 10). For the components shown in Tables 9 and 10, the coefficients are below 4.0 for all countries, with the only exception of Korea, for property income, and of Mexico, for property income and mixed income. In the case of Mexico, the adjusted national accounts total is more than 7 times higher than micro total (Annex 4).

Table 9: Adjustment coefficient for the income components whose distribution was based on Method A

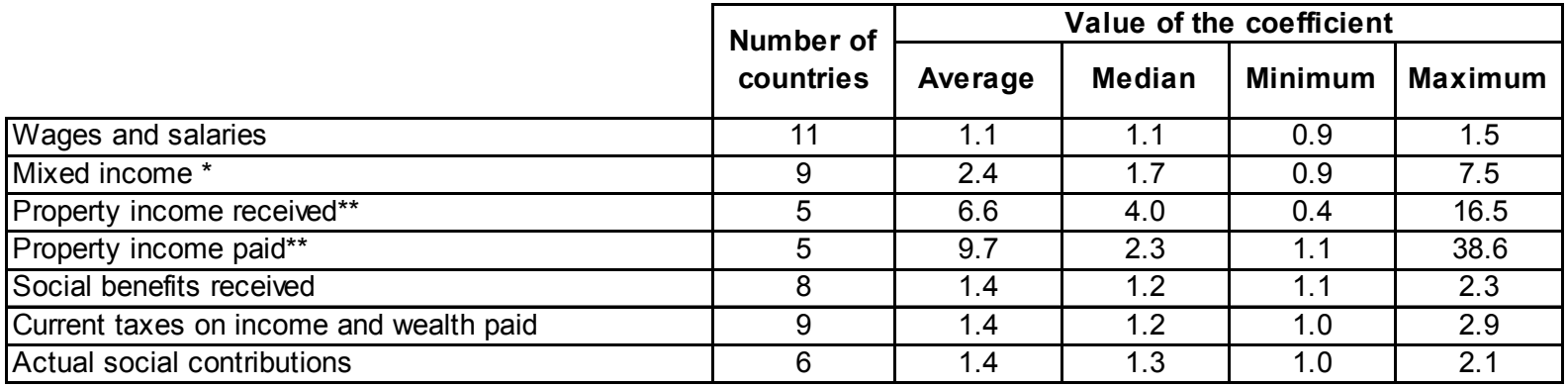

* Excluding the adjustment for underground production and own account production.

** $\quad$ Before allocating FISIM to consumption and excluding income attributed to insurance policy holders.

Note: Method A was applied to allocate the adjusted national accounts total for wages and salaries for eleven countries. Among these countries, the adjusted national account total is, on average, 1.1 times higher than the corresponding micro total, ranging between 0.9 and 1.5 times across countries. 
STD/DOC(2013)4

Table 10: Adjustment coefficient for the consumption components whose distribution was based on Method A

\begin{tabular}{|c|c|c|c|c|c|}
\hline & \multirow{2}{*}{$\begin{array}{l}\text { Number of } \\
\text { countries }\end{array}$} & \multicolumn{4}{|c|}{ Value of the coefficient } \\
\hline & & Average & Median & Minimum & Maximum \\
\hline Food and non-alcoholic beverages* & 12 & 1.5 & 1.2 & 1.0 & 4.1 \\
\hline Alcoholic beverages* & 12 & 4.1 & 2.0 & 1.2 & 25.3 \\
\hline Tobacco & 12 & 3.3 & 2.6 & 2.1 & 10.9 \\
\hline Clothing and footwear & 12 & 1.3 & 1.3 & 1.0 & 2.2 \\
\hline Actual rentals for housing & 12 & 1.4 & 1.0 & 0.6 & 4.4 \\
\hline Imputed rentals for housing & 8 & 1.0 & 1.0 & 0.6 & 1.6 \\
\hline $\begin{array}{l}\text { Maintenance and repair of the dwelling, water supply } \\
\text { and miscellaneous services }\end{array}$ & 11 & 1.4 & 1.2 & 0.2 & 3.6 \\
\hline Electricity, gas and other fuels & 12 & 1.2 & 1.1 & 0.9 & 2.5 \\
\hline $\begin{array}{l}\text { Furnishings, household equipment and routine } \\
\text { households maintenance }\end{array}$ & 12 & 1.6 & 1.4 & 0.9 & 3.0 \\
\hline Medical products, appliances and equipment & 10 & 1.9 & 1.3 & 0.8 & 7.6 \\
\hline Outpatient services & 9 & 2.4 & 1.7 & 0.7 & 7.7 \\
\hline Hospital services & 8 & 10.8 & 7.7 & 1.3 & 37.4 \\
\hline Purchases of vehicles & 11 & 2.0 & 1.3 & 0.7 & 8.0 \\
\hline Operation of personal transport equipment & 10 & 1.5 & 1.2 & 0.7 & 5.1 \\
\hline Transports services & 10 & 2.0 & 1.9 & 1.0 & 4.5 \\
\hline Communications & 11 & 1.4 & 1.3 & 0.9 & 3.4 \\
\hline Recreation and culture & 11 & 1.7 & 1.7 & 0.8 & 3.4 \\
\hline Education & 10 & 1.1 & 1.1 & 0.6 & 2.0 \\
\hline Restaurants and hotels & 11 & 1.6 & 1.4 & 0.8 & 2.9 \\
\hline Miscellaneous goods and services ${ }^{\star \star}$ & 10 & 1.9 & 1.9 & 1.2 & 2.7 \\
\hline Insurances expenditures & 5 & 1.3 & 0.7 & 0.5 & 2.5 \\
\hline
\end{tabular}

Note: Method A was applied to allocate the adjusted national accounts total for food and non-alcoholic beverages for twelve countries. Among these countries, the adjusted national total is, on average, 1.5 times higher than the corresponding micro total, ranging between 1.0 and 4.1 times across countries.

69. Method B based on imputed distributional information was applied to Social Transfers in Kind for education and health in most countries and, to mixed income from underground production in a few countries (step 2). Method B based on micro proxies was mainly applied for income components, assuming information on the distribution of the component considered was proportionate to the proxy; for examples, actual social contributions were distributed using information on households wages and salaries (in Australia, New-Zealand, Slovenia, Sweden and the United States); income from underground production was distributed using information on mixed income (in Australia, France, Korea, Mexico, Sweden, Switzerland and the United States). For other components, the proxy information used differed across countries. Thus, for example, indirectly measured financial intermediation services (FISIM) was distributed based on information on the distribution of deposits and loans hold by households; based on information on the distribution of interest received and paid; and/or based on information on the distribution of income from mixed income for business loans. Also, property income attributed to insurance policy holders was distributed using information on household holding net equity in pension funds, insurance premiums paid and/or property income received.

70. The use of various proxies reflects the availability of micro information and the nature of the component. For example, in the Netherlands, information on holders of net equity in pension funds ${ }^{16}$ were

16 In the Netherlands, information on households holding of superannuation is available in the micro survey. Statistics Netherlands composes a statistic about the future pension benefits of households. This statistics is converted into the wealth of household in Net equity of households in pension funds reserves (AF.612). 
used to allocate property income attributed to insurance policy holders as the largest part of this component is made up of pension funds; on the other hand, in the United States and Mexico, information on the distribution of non-life insurance premiums paid was used as a proxy as in these two countries the largest share of this item is accounted by income from non-life insurance technical reserves. Also, some countries used different proxies for the same component. In the case of the United States for example, charges for indirectly measured financial intermediation services applied to four types of loans and five types of deposits (e.g. non corporate business deposits, loans of owner-occupied, household consumer credit) were distinguished; for each of these items a specific proxy was used.

71. Method C was rarely used to distribute the components of the Expert Group template. Method C was applied by a few experts mainly to distribute the 'other STiK' (that includes all the spending by NPISH and part of the government spending benefitting households to cover various needs other than health and education) and the 'net non-life insurance premiums minus claims' components.

Methodological issues

72. The approach used in this paper to allocate the national accounts totals raises a number of methodological issues: i) homogeneity across micro sources; ii) choice of the reference demographic series; iii) sample size; and iv) impact of the assumptions made on the final estimates.

73. Homogeneity across micro sources - The calculation was performed component by component so as to allow experts to make use of different micro sources depending on the component considered. All the income and consumption components were then combined to measure the national accounts aggregates, e.g. adjusted disposable income, actual final consumption and saving, by household groups. This approach assumes that, for each household group the various micro sources used describe, on average, the same type of households. If, in reality, the $20 \%$ poorest households in the Income Survey are different from the $20 \%$ poorest households in the Household Budget Survey, the measures of the national accounts aggregates per household group used in this paper will be impacted. Addressing this issue would require matching the micro sources prior to the calculation.

74. Reference demographic series - The approach relies on a reference series on the number of households in each household group. To be consistent across components, the same series on the number of households $\left(n_{i}\right.$ for $\left.i=\{1, \ldots, l\}\right)$ should be used to allocate each income and consumption component. There is, however, no official series providing data on the number of households in each group; and estimates may differ depending on the micro data source used. In the context of the Expert Group work, each national expert chose the most relevant series.

75. Sample size - The distributional information used to apply Methods A and B is based on per household averages based on micro sources. The robustness of these averages depends on the sample sizes of the different micro sources. These range from 2,120, for the Household Budget Survey in Sweden, to 91,325 for the Income Panel Survey in the Netherlands. The number of households is lower than 100 households for a few countries and specific groups, i.e. for singles aged 65 and over and the household mainly relying on property income and income from self-employment (see information on sample sizes available at http://www.oecd.org/std/WP-STD-2013-4-1.xlsx).

76. Impact of assumptions on results - When using Method $\mathrm{B}$, the assumptions made to allocate totals to households and/or to use a micro proxy can impact on the overall final distribution (see part III). Making some choices is, however, inevitable to produce disparity indicators consistent with national accounts totals. 


\section{Results}

77. This section presents results on disparities in household income, consumption and saving across households that are derived from micro and macro sources. The first sub-section defines the disparity indicators used here while the second, third and fourth subsections present results on, respectively, income, consumption, and the savings rate ${ }^{17}$. The fifth subsection concludes with a sensitivity analysis and a comparison with other international data on income disparity. Country results on various income and consumption aggregates are available at http://www.oecd.org/std/WP-STD-2013-4-3.xlsx.

\section{A. Indicators}

\section{From subtotals to measures per household and per consumption unit}

78. The various breakdowns performed by national experts provide information on how the national accounts totals are distributed among household groups. The share of the income received (or expenditure spent) by a given group can be compared across household groups and across countries. This analysis is complemented with measures per household and per consumption unit, which take into account differences in the number of households and in their composition across household groups. For a given household group $i$ and component $X$, average measure per household (hh) and per consumption unit (cu) are computed as follows:

$$
\begin{aligned}
& \bar{X}_{i}^{N A_{-} a d j} h h=\frac{z_{i}^{N A_{-} a n j}}{n i} \\
& \bar{X}_{i}^{N A_{a} a d j} c u=\frac{X_{i}^{N A n d i}}{e u_{i}}
\end{aligned}
$$

Using the notation:

$\mathrm{X}$ : income/consumption component

$i=\{1, \ldots, I\}$ to identify household groups

$n_{i}$ : for the total number of households in group $i$

$c u_{i}$ : for the total number of consumption units in group $i$

$X_{i}^{\text {NA_ad }}$ : for the adjusted ${ }^{18}$ national accounts subtotal for group $i$

79. The above indicators describe an average household in the group $i$. With respect to the equivalized income quintile classification, estimates per household and per consumption unit for the quintile Q3 are considered as proxies for the median household in each country.

80. Compiling measures per consumption unit raise two issues: the choice of the equivalence of scale, and the need to compute estimates at the aggregate level. Consumption units are obtained using an equivalence of scale that allows for the fact that two people living together can achieve some economies of scale in consumption, in relation to housing expenditures for instance; and small children consume less than working adults. The Oxford-modified equivalence scale (also known as the OECD modified scale) is

17 Since not all experts fully completed the Expert Group template, the number of countries presented may differ according to the indicator studied.

For more explanation on adjustment, see section II.C. of this paper, step 1 "adjustment of national accounts totals". 
used in this study, even if this scale may not be the most suitable when studying income and consumption measures that include Social Transfers in Kind (Box 3).

81. The computation of averages per consumption unit is performed at the aggregate level, i.e. at the level of each household group implying that estimates of the number of consumption units in each household group are needed. Estimating such a series is somewhat problematic, as the relevant series may differ depending on the micro source used for the estimation. Also, calculation at the aggregate level may overestimate the weight of large households, compared to micro sources ${ }^{19}$.

\section{Box 3 - Choice of the equivalence of scale}

Choices on the most appropriate equivalence scales differ across international organisations (e.g. micro analysis at Eurostat rely on the Oxford-modified equivalence scale whereas the OECD typically uses a square root of household size) mainly because of different goals and priorities.

For the purpose of this study, the Oxford-modified equivalence scale was chosen as this is the most commonly used across the countries represented in the Expert Group. Based on this scale, within each household, the first adult counts 1 , all children under 14 for 0.3 , and any additional persons aged 14 and over for 0.5 .

Choices on the most appropriate scale should ideally take into account what are the household characteristics that are considered when assessing needs to establish the scale. This matters, especially when applying equivalence scale to aggregates including Social Transfers in Kind. A summary of this issue can be found in Verbist G., Förster M. and Vaalavuo M. (2012). "In distributional studies, it is common practice to correct household income with an equivalence scale to take account of economies of scale: the needs of a household grow with each additional member, but not in a proportional way [...] But when non-cash income components are included, this may give rise to what Radner (1997) has called the "consistency" problem: some types of non-cash income may have needs associated with them that are unmeasured in usual equivalence scales. The question is particularly relevant in the case of poverty analysis, as inclusion of non-cash incomes can represent considerable relative changes in income to low income households. Consider two single-person households with each USD 1000 cash income. Person A is ill and receives public health care worth USD 200, whereas person $B$ is healthy and needs no health care. Consequently, person A could be said to have $20 \%$ more needs than B because of differences in health care needs, and his equivalence scale should be 1.2 compared to 1 for B."

19 Estimating average equivalized income for household group $i$ at the micro level would imply giving to each household of the group the same weight as follows: $\bar{X}_{\mathrm{i}}$ per $c u=\frac{1}{n_{i}} \sum_{\mathrm{i}=1} \frac{x_{h}}{\mathrm{w}_{\mathrm{h}}}$; The aggregated calculation implicitly weights the household equivalized income using the number of consumption units, as follows: $\quad \bar{X}_{\mathrm{i}}^{N A_{-} \mathrm{ad}}$ per $c u=\frac{x_{i}^{N A_{-} a l}}{c u_{i}}=\alpha \times \frac{\sum_{h \in i} x_{h}}{\sum_{h \in i} c u_{h}}=\frac{\alpha}{\sum_{h \in i} c u_{h}} \sum_{h \in i} c w_{h} \times \frac{x_{h}}{c u_{h}}$. In the above formulas, $i=\{1, \ldots, I]$ identifies the household group; $h=[1, \ldots, N]$ identifies each household with $\mathrm{N}$ being the total number of household in the population; $n_{i}$ is the total number of households in group $i$; $c u_{\hbar}$ is the number of consumption unit in household $h$ with $c u_{i}=\Sigma_{h i} c u_{h} x_{h}$ is the income of household $h$; and $a$ is the adjustment coefficient to national account total (see part II.C - step 4). 


\section{Three main indicators of disparities across households}

82. Within each country disparities among households is analysed based on three ratios:

- The ratio to the average is the ratio of the value for each household group relative to the average household value and computed as follows, for a given household group i:

Ratio to average $=\frac{\bar{X}_{i}^{\text {NA_adj }}}{\bar{X}^{\text {MAadi }}}$

- The ratio of the highest to lowest is the ratio of the value for the highest household group to the lowest household group value. It is computed as follows, for a given classification of household $\mathrm{z}$ (i.e., Equivalized Disposable Income quintile, Main Source of Income and Household Type):

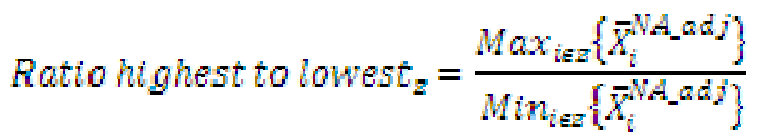

- The disparity index is the coefficient of variation showing the variation from the average. For a given classification of households (i.e., Equivalized Disposable Income quintile, Main Source of Income and Household Type); the coefficient of variation (CV) is the ratio of the standard deviation to the mean calculated as follows:

$C V_{z}=\frac{\sqrt{\frac{1}{N} \times \sum_{i \in z}\left[n_{i} \times\left(\bar{X}_{i}^{N A_{-} a d j}-\bar{X}^{N A_{-} a d j}\right)^{2}\right]}}{\bar{X}^{N A_{-} a d j}} * 100$

$\bar{X}^{N A_{-} a d j}=\frac{1}{N} \sum_{i \in \Xi} n_{i} \times \bar{X}_{i}^{N A_{-} a d j}$

In the above formulas:

$\mathrm{X}$ : income/consumption component

$z=\{M S I, E D I, H T\}$ identifies the household classification variable

$i=[1, \ldots, I]$ identifies each household group

$n_{i}$ : is the total number of households in group $i$

$\mathrm{N}$ : is the total number of households in the population

$\bar{X}_{i}^{N A_{-} a d j}:$ is the per household or per consumption unit adjusted national accounts for group $i$

$\bar{X}^{\text {NA_adj }}$ is the per household or per consumption unit adjusted national accounts 
83. When analyzing the above disparity index, two properties need to be taken into account:

- Firstly, the above calculation assumes that each household receives (or spends) the average income (or expenditures) of his group, i.e. that disparity within a household group is supposed to be zero, implying that the disparity index underestimates household disparities; this remark is of less importance when considering the income quintile classification as households are classified according to their income level;

- Secondly, the results for the above disparity index depend on the household structure in each country. Consequently, divergences in coefficient of variations between two countries may be explained by two factors: differences across countries in the extent to which one given household group departs from the average; and cross country differences in the share of the household groups in the total household population. The impact of the household structure on the results for the disparity index is presented in Annex 5.

\section{B. Income}

84. This subsection presents the results on income disparity across households with a particular focus on primary income and adjusted disposable income, measured on a per consumption unit basis. Results are presented successively for the ratio to the average, the ratio of the highest to lowest, and the disparity index. Only a restricted set of countries is shown here because not all countries could provide all the information needed to compile an estimate (or proxy) of the macro aggregates measured on a per consumption unit basis.

85. Ratio to the average - The ratio to the average makes clear which household groups are far from the average. In this respect, the richest households have significantly higher incomes than the average household especially in Mexico and, to a lesser extent, in the United States. The income of the richest household group is between 1.6 times the average in Slovenia and 3.2 times the average in Mexico (Figure 5). The households whose main source of income is property income also show income levels that are significantly higher than the average, from 1.5 in Korea to 8.9 in Mexico. Some countries show particular results, among which Mexico where single adults under the age of 65 receive income that is 1.6 times higher than the average income (Table 11).

86. On the other hand, the first quintile is $24 \%$ of the average in Mexico in contrast to $65 \%$ in Slovenia. Households whose main source of income is current transfers are showing the lowest values in most countries: from 56\% of the average income in Mexico to $84 \%$ in Italy. To a lesser extent, also single adults with children living at home show relatively low levels of income, from $71 \%$ of the average in New Zealand to $85 \%$ in Korea. Again, some countries shows rather specific results, in particular in Korea where single adults aged 65 and over receive, on average, an income equal to $47 \%$ of the average.

87. In all countries the median income, approximated by the average income of the median quintile Q3 is lower than the average income. The median income accounts for $54 \%$ of the average in Mexico in contrast to $95 \%$ of the average in the Netherlands. The Netherlands shows a particularly flat distribution in the middle of the distribution. 
Figure 5: Relative position of each household group compared to the average, by Equivalized Disposable Income quintile

Adjusted disposable income per consumption unit for each group to the average adjusted disposable income per consumption unit in the country

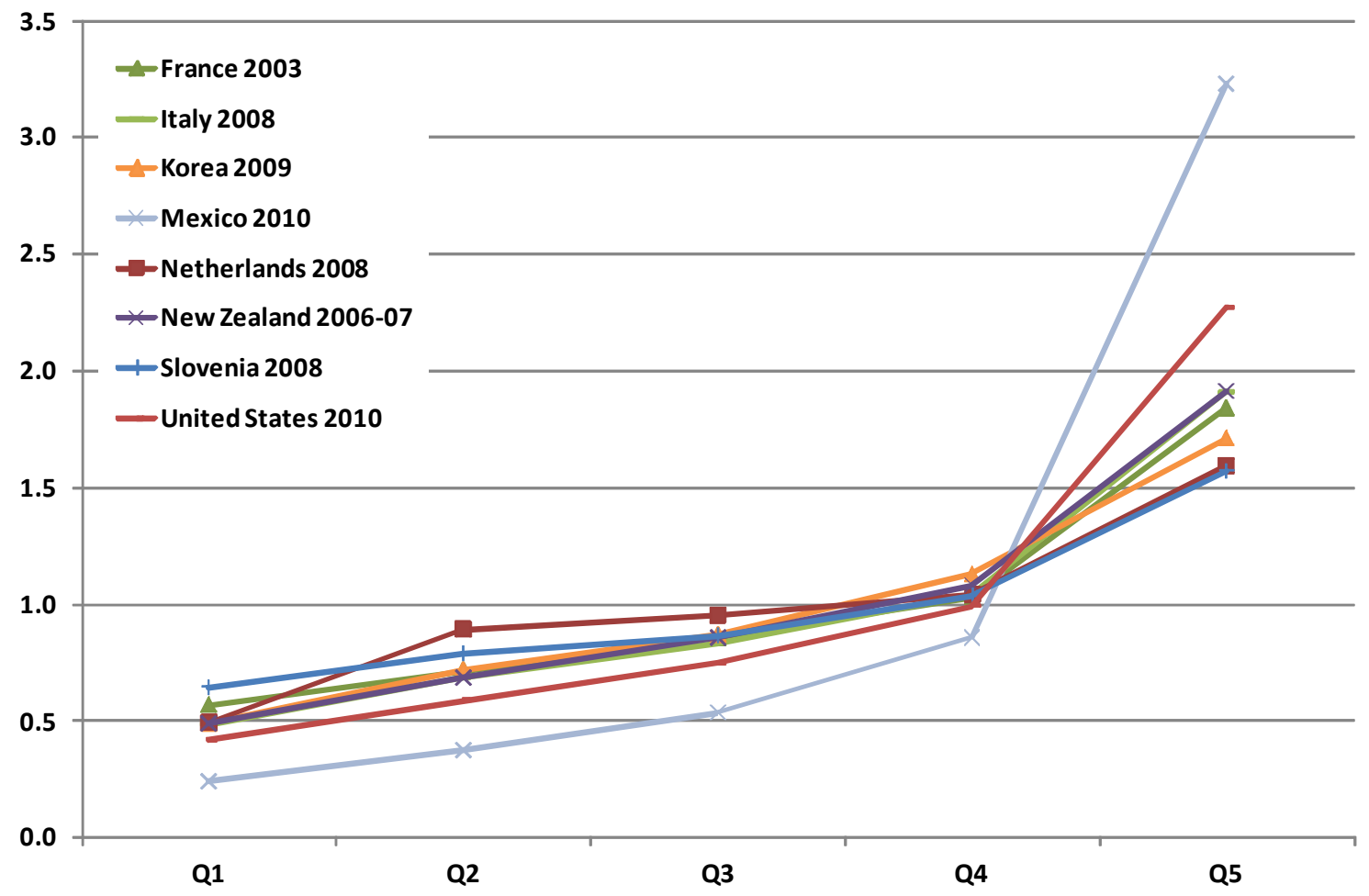

Table 11: Relative position of each household group compared to the average, by Main Source of Income and Household Type

Adjusted disposable income per consumption unit for each group to the average adjusted disposable income per consumption unit in the country

\begin{tabular}{|c|c|c|c|c|c|c|c|c|}
\hline & $\begin{array}{c}\text { France } \\
2003\end{array}$ & Italy 2008 & Korea 2009 & $\begin{array}{c}\text { Mexico } \\
2010\end{array}$ & $\begin{array}{l}\text { Netherlands } \\
2008\end{array}$ & $\begin{array}{c}\text { New } \\
\text { Zealand } \\
2006-07\end{array}$ & $\begin{array}{c}\text { Slovenia } \\
2008\end{array}$ & $\begin{array}{c}\text { United } \\
\text { States } \\
2010 \\
\end{array}$ \\
\hline & \multicolumn{8}{|c|}{ Main Source of Income } \\
\hline Wages and salaries & 1.1 & 0.9 & 1.1 & 0.6 & 0.9 & 1.0 & 1.0 & 1.0 \\
\hline \begin{tabular}{|l} 
Income from self-employment \\
\end{tabular} & 1.6 & 1.4 & 0.9 & 1.4 & 1.8 & 1.2 & 1.6 & 1.5 \\
\hline Property income & 2.0 & 1.8 & 1.5 & 8.9 & 2.9 & 2.0 & 1.5 & 2.8 \\
\hline \multirow[t]{2}{*}{ Transfers \& others } & 0.8 & 0.8 & 0.7 & 0.6 & 1.0 & 0.8 & 0.8 & 0.8 \\
\hline & \multicolumn{8}{|c|}{ Household Type } \\
\hline Single under 65 & 0.8 & 1.0 & 0.9 & 1.6 & 0.7 & 0.9 & 0.7 & 0.8 \\
\hline Single 65 and over & 0.9 & 0.8 & 0.5 & 0.8 & 1.1 & 1.1 & 0.7 & 0.9 \\
\hline Single with children living at home & 0.8 & 0.8 & 0.8 & 0.8 & 0.8 & 0.7 & 0.8 & 0.7 \\
\hline Two adults under 65 no child living at home & 1.2 & 1.1 & 1.1 & 1.5 & 1.1 & 1.2 & 1.0 & 1.2 \\
\hline Two adults at least one 65 and over no child living at home & 1.0 & 1.0 & 0.8 & 1.1 & 1.2 & 1.3 & 1.0 & 1.2 \\
\hline Two adults with less than 3 children living at home & 1.0 & 1.0 & 1.1 & 1.1 & 1.0 & 1.0 & 1.0 & 1.0 \\
\hline Two adults with at least 3 children living at home & 0.9 & 0.9 & 1.0 & 0.9 & 1.0 & 0.8 & 1.0 & 0.9 \\
\hline Others & 1.0 & 1.0 & 1.0 & 0.9 & 1.1 & 1.0 & 1.1 & 0.9 \\
\hline
\end{tabular}

Note: In France, the adjusted disposable income per consumption unit of the households for which the main source of income are wages and salaries is on average 1.1 times higher than the average per consumption unit adjusted disposable income in the country.

88. Ratio highest to lowest - The income quintile grouping is the only grouping for which all countries compare the same household groups for the ratio of the highest to lowest, i.e the $20 \%$ poorest households (Q1) and the 20\% richest households (Q5). In Mexico, on average, the richest households 
receive an adjusted disposable income which is 13.3 times higher than the one received by the poorest households (Figure 6). In other countries, this ratio ranks from 2.4 in Slovenia to 5.4 in the United States.

Figure 6: Relative position of the $20 \%$ richest households to the $20 \%$ poorest households Adjusted disposable income per consumption unit for the fifth quintile to the adjusted disposable income for the first quintile

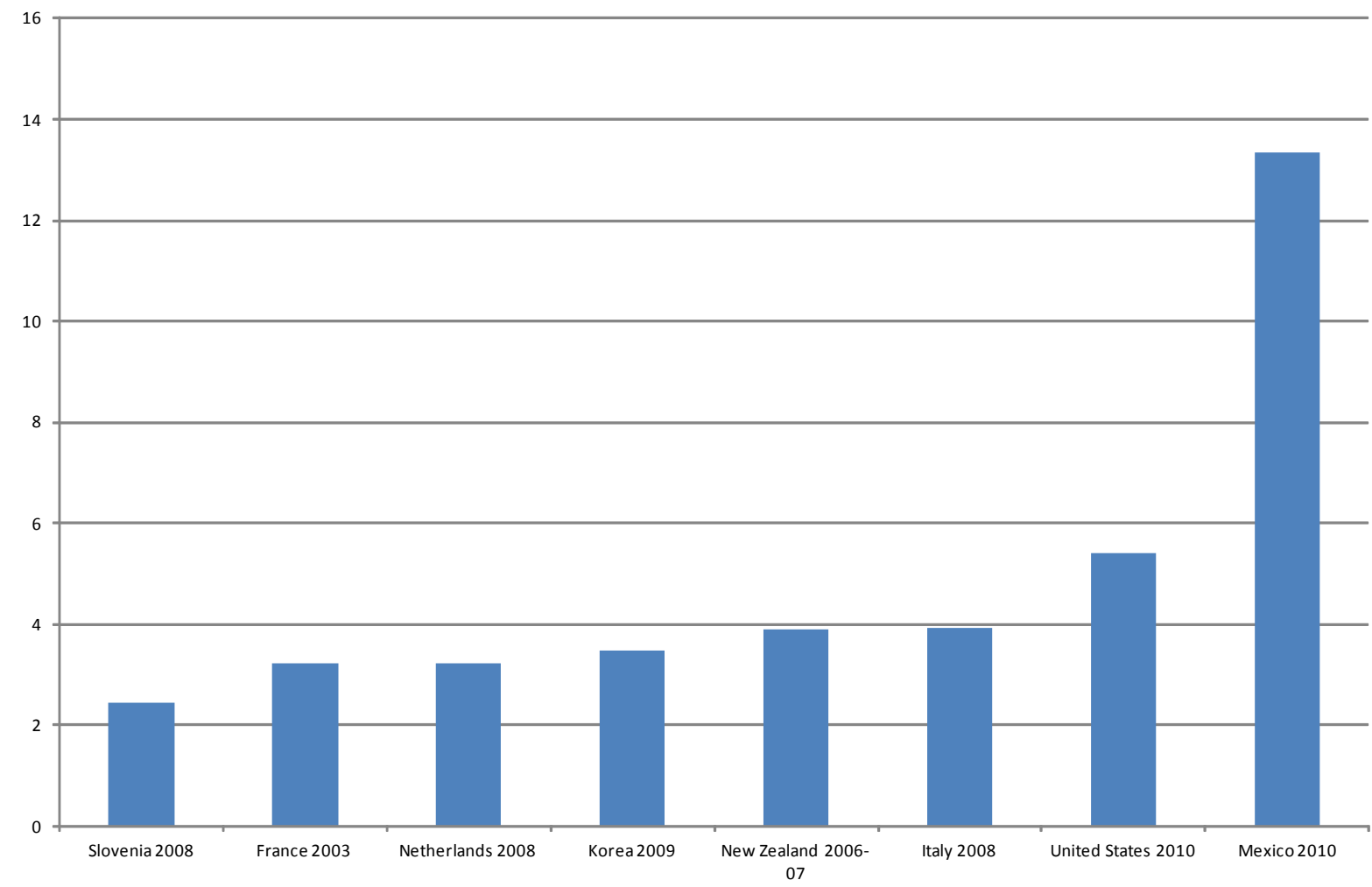

89. Disparity index - As stated before, the disparity index shows how much dispersion exists from the average across all household groups for each classification variable:

- Measures across income quintiles highlight high levels of income disparity and large difference across countries for the adjusted disposable income per consumption unit: the disparity index ranks from $32 \%$ in Slovenia to $66 \%$ in the United States and $111 \%$ in Mexico (Figure 7). Income disparity is thus 3.5 times higher in Mexico (2.1 in the United States) than in Slovenia.

- Measures across households classified by Main Source of Income shows high disparities and heterogeneity. This is partially explained by the particularly high disparity index in Mexico which is due to the very high levels of income received by households who mainly rely on property income have compared to the average. Results on disparity index tend to show that these households are concentrated on the very top of the fifth quintile. Once Mexico is excluded from the comparison, the Main Source of Income classification presents lower heterogeneity between the two extreme countries as compared to the income quintiles classification: income disparity in the United States is 1.8 times higher than in Korea when households are classified by Main Source of Income.

- Measures across households classified by Household Type show heterogeneity across countries but relatively low levels of income disparity: income disparity is 2.8 times higher in Mexico (respectively 2.1 in the Netherlands) than in Italy, where the disparity index is $8 \%$. 
90. Overall, Mexico is showing the highest disparity across households whatever the household grouping. For the other countries, the cross country comparison depends on the household grouping: e.g., the Netherlands is among the countries showing the lowest disparity by income quintile and among the highest by Main Source of Income.

Figure 7: Income disparity index for the three household classifications

Disparity index on adjusted disposable income per consumption unit

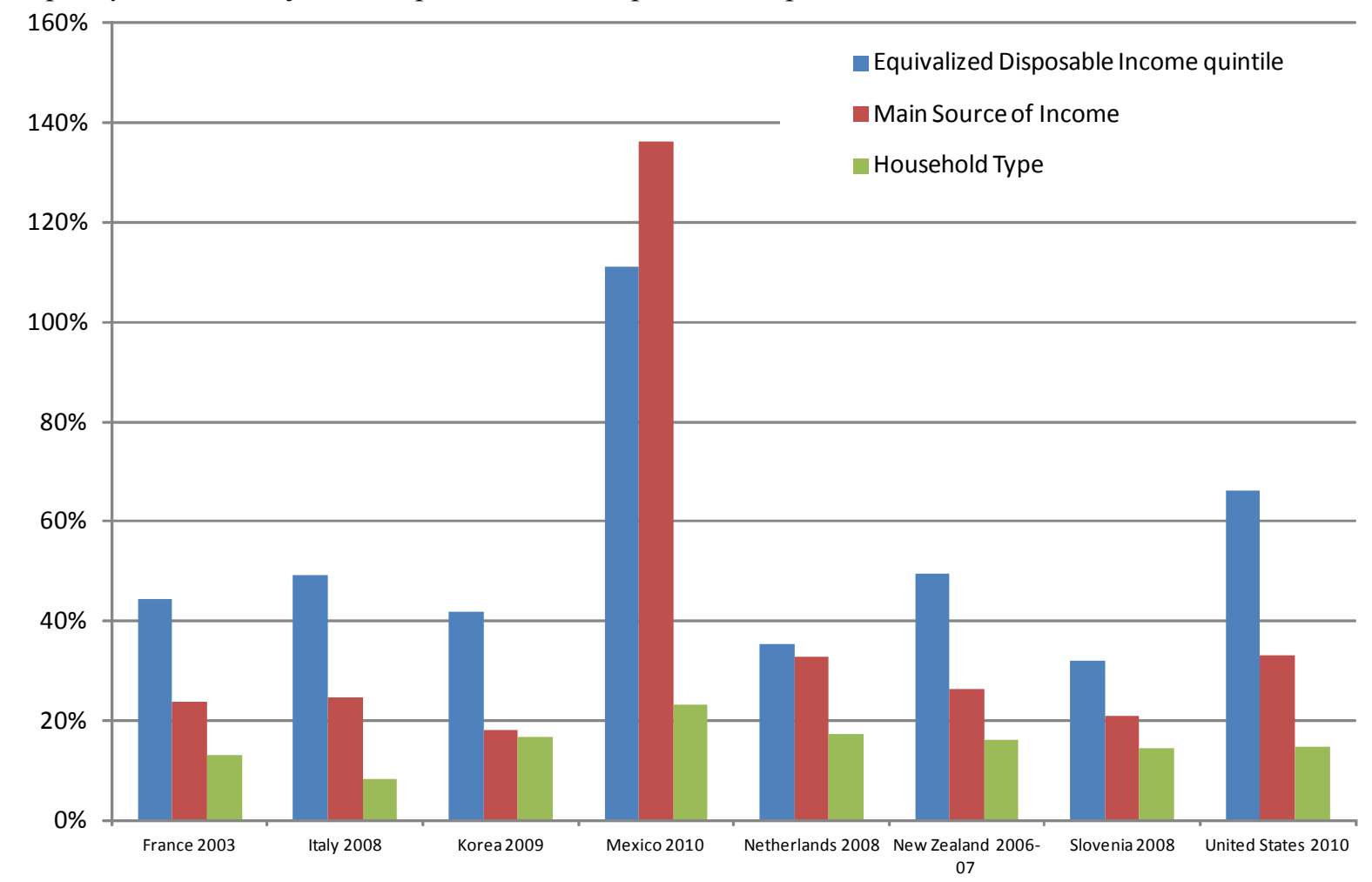

91. Impact of net current transfers on income disparity - The relative position of each household group compared to the average is different when measured on primary income, i.e. before deducting any income taxes and social contributions paid and adding transfers in cash and in kind. Comparing this ratio to the one for adjusted disposable income illustrates how net current transfers, mainly related to the intervention of general government and private pension insurance, brings some household groups closer to the average. The household groups that most significantly come closer to the average are single adults aged 65 and over and households made up of two adults with at least one adult aged 65 and over and no child living at home (Figure 8). The large increases for households including people aged 65 and over are mainly due to pensions from collective schemes and Social Transfers in Kind. The Netherlands presents the extreme case where, on average, a single adult 65 and over receives a primary income equal to $30 \%$ of the average household and has an adjusted disposable income that is $10 \%$ higher than the average household (i.e. the ratio to the average increased by 0.8 point). 
Figure 8: Impact of net transfers on the relative position of each household group compared to the average, by Household Type

Adjusted disposable income per consumption unit for each group to the adjusted disposable income per consumption unit average minus primary income per consumption unit to the primary income per consumption unit average

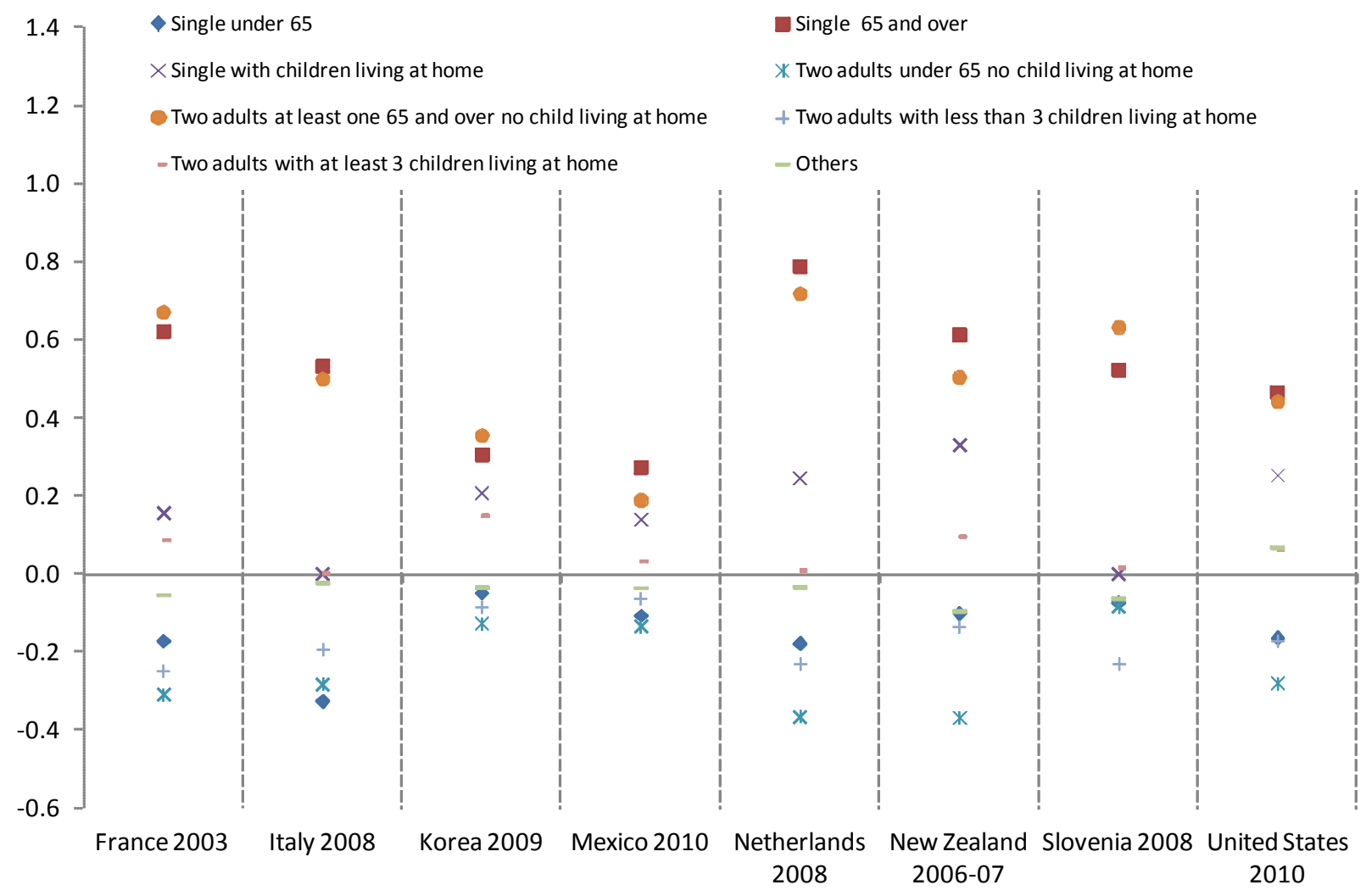

Note: In France, the relative position of single adults aged 65 and over compared to the average is increased by around 0.6 point thanks to the net current transfers; the relative position to the average is 0.3 on primary income and 0.9 on adjusted disposable income.

92. Also, the income gap between the $20 \%$ richest households and the $20 \%$ poorest households is significantly higher in the United States and New Zealand when measured on primary income. Net current transfers reduce the income disparity between the richest and the poorest households by 9.0 points in the United States and by 8.8 points in New Zealand (Table 12). 
Table 12: Impact of net transfers on the relative position of richest households to the poorest households

Primary income and adjusted disposable income per consumption unit: value for the fifth quintile to the first quintile; and difference in points

\begin{tabular}{|l|c|c|c|c|c|c|c|c|}
\cline { 2 - 9 } \multicolumn{1}{c|}{} & $\begin{array}{c}\text { France } \\
2003\end{array}$ & Italy 2008 & $\begin{array}{c}\text { Korea } \\
2009\end{array}$ & $\begin{array}{c}\text { Mexico } \\
2010\end{array}$ & $\begin{array}{c}\text { Netherlan } \\
\text { ds } 2008\end{array}$ & $\begin{array}{c}\text { New } \\
\text { Zealand } \\
2006-07\end{array}$ & $\begin{array}{c}\text { Slovenia } \\
2008\end{array}$ & $\begin{array}{c}\text { United } \\
\text { States } \\
2010\end{array}$ \\
\hline Primary income (1) & 8.3 & 7.7 & 6.0 & 20.3 & 5.7 & 12.7 & 4.7 & 14.5 \\
\hline Adjusted disposable income (2) & 3.2 & 3.9 & 3.5 & 13.3 & 3.2 & 3.9 & 2.4 & 5.4 \\
\hline Impact =(2)-(1) & -5.0 & -3.8 & -2.5 & -7.0 & -2.4 & -8.8 & -2.3 & -9.0 \\
\hline
\end{tabular}

93. Although some countries, in the national accounts context, compile "from whom to whom" tables (which register flows between institutional sectors), traditionally the national accounts do not take into account the income flows received and paid among households. Indeed, because the preliminary focus of national accounts is to study households as a whole, the intra-household income flows are generally not estimated. Once the household national accounts totals are broken down by household group, however, analyzing income flows from one household group to another may become quite relevant. Only a few countries, namely France, Korea, the United States and the Netherland estimated per consumption unit adjusted disposable income including transfers between households. Results show, however, no significant impact on the disparity index and on the ratio of the richest to the poorest (Table 13). Korea shows the highest impact with a reduction of the disparity index by 3 points for the Main Source of Income grouping and by 2 points for the Household Type grouping.

Table 13: Impact of the inclusion of transfers between households on the disparity index and on the relative position of the richest households to the poorest households

Adjusted disposable income per consumption unit without/with transfers between households

\begin{tabular}{|c|c|c|c|c|c|c|c|c|c|c|c|c|}
\hline & \multicolumn{9}{|c|}{ Disparity index, by household grouping: } & \multirow{2}{*}{\multicolumn{3}{|c|}{$\frac{\text { Ratio highest to lowest }}{\text { Q5/Q1 }}$}} \\
\hline & \multicolumn{3}{|c|}{$\begin{array}{l}\text { Equivalized Disposable } \\
\text { Income quintile }\end{array}$} & \multicolumn{3}{|c|}{ Main Source of Income } & \multicolumn{3}{|c|}{ Household Type } & & & \\
\hline & Without & \begin{tabular}{|l|} 
With \\
\end{tabular} & Impact & Without & With & Impact & Without & \begin{tabular}{|l|} 
With \\
\end{tabular} & Impact & Without & With & Impact \\
\hline France 2003 & $45 \%$ & $43 \%$ & $-1 \%$ & $24 \%$ & $25 \%$ & $1 \%$ & $13 \%$ & $12 \%$ & $-1 \%$ & 3.2 & 3.1 & -0.1 \\
\hline Korea 2009 & $42 \%$ & $42 \%$ & $0 \%$ & $18 \%$ & $16 \%$ & $-3 \%$ & $17 \%$ & $15 \%$ & $-2 \%$ & 3.5 & 3.5 & 0.0 \\
\hline Netherlands 2008 & $35 \%$ & $35 \%$ & $0 \%$ & $33 \%$ & $33 \%$ & $0 \%$ & $17 \%$ & $17 \%$ & $0 \%$ & 3.2 & 3.2 & 0.0 \\
\hline United States 2010 & $66 \%$ & $66 \%$ & $0 \%$ & $33 \%$ & $33 \%$ & $0 \%$ & $15 \%$ & $15 \%$ & $0 \%$ & 5.4 & 5.4 & 0.0 \\
\hline
\end{tabular}

Note: in France, the disparity index for the Equivalized Disposable Income grouping equals $45 \%$ when measured on the adjusted disposable income per consumption unit. Introducing transfers between households would reduce the disparity index by 1 percentage point.

\section{Consumption}

94. This subsection presents results on consumption disparities across households, with a particular focus on actual final consumption measured on a per consumption unit basis. Results are presented for all three indicators: the ratio to the average, the ratio of the highest to lowest, and the disparity index. Only a restricted set of countries is shown here because not all countries could provide all the information needed to compile an estimate (or proxy) of the macro aggregates measured on a per consumption unit basis.

95. Ratio to average - Only a few household groups in a limited number of countries show consumption levels per consumption unit significantly higher than the average (Figure 9, Table 14): the fifth quintile in Mexico (ratio of 2.0); households whose main source of income is property income in Mexico and the United States (2.1 for both countries); households mainly relying on income from self- 
employment in France (1.8); single adults under the age of 65 in Mexico (1.8); and households made up of two adults with at least three children in Italy (1.6).

96. On the other hand, the level of consumption of the poorest households is significantly lower than the average in most countries except in Slovenia and in the United States. Disregarding the two latter countries, Figure 9 shows that on average, the consumption of the $20 \%$ poorest households equals $48 \%$ of the average consumption in Mexico to $73 \%$ in New Zealand. Other households groups in a few countries present consumption level significantly lower than the average: in Italy and Slovenia for the household group "other" which includes households with more than two adults, and in Korea for single adults aged 65 and over and households made up of two adults at least one aged 65 and over with no child.

Figure 9: Relative position of each household group compared to the average, by Equivalized Disposable Income quintile

Actual final consumption per consumption unit for each group to the average actual final consumption per consumption unit in the country

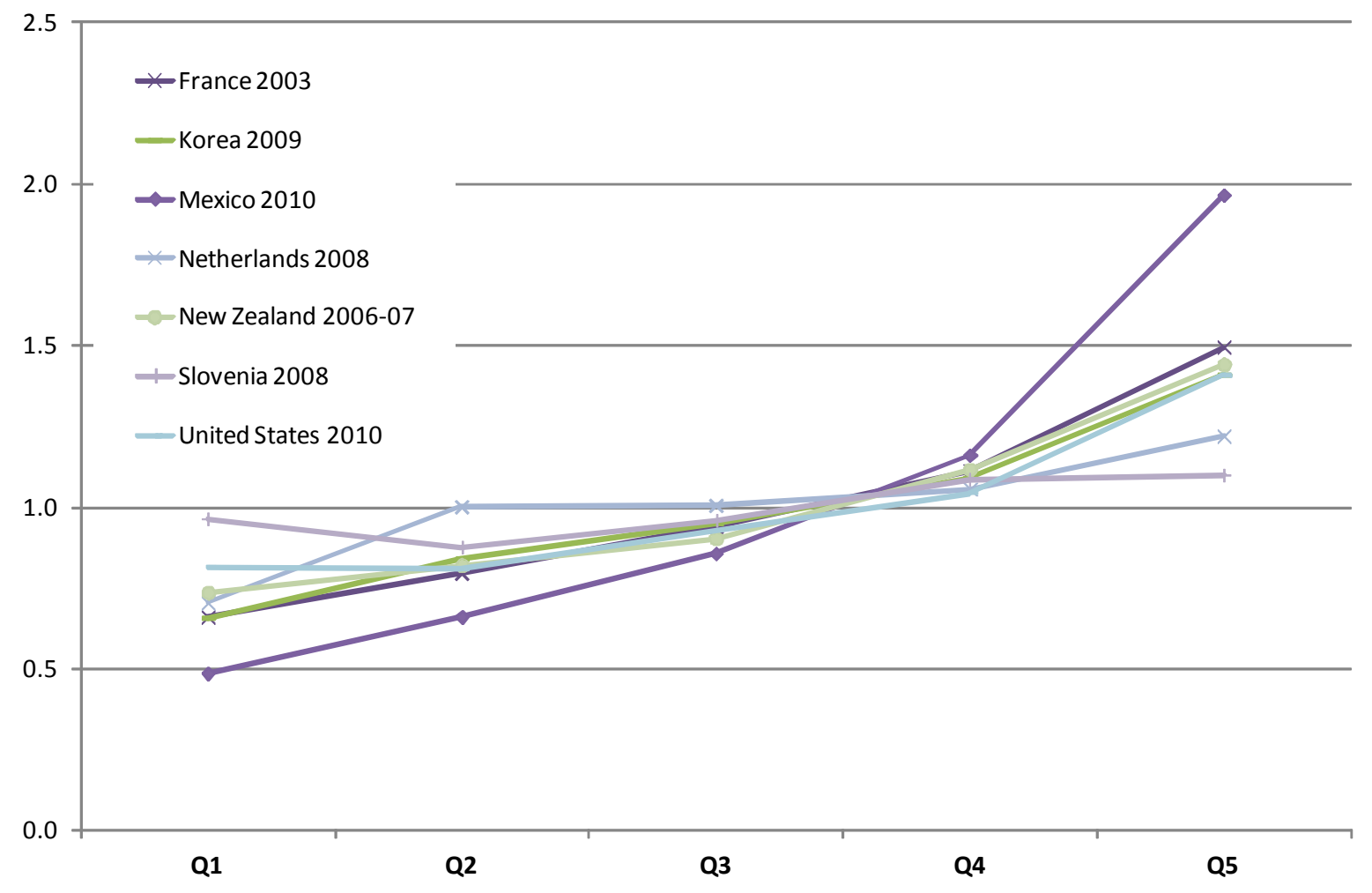


Table 14: Relative position of each household group compared to the average, by Main Source of Income and Household Type

Actual final consumption per consumption unit for each group to the average actual final consumption per consumption unit in the country

\begin{tabular}{|c|c|c|c|c|c|c|c|c|}
\hline & $\begin{array}{c}\text { France } \\
2003\end{array}$ & $\begin{array}{l}\text { Italy } \\
2008\end{array}$ & $\begin{array}{c}\text { Korea } \\
2009\end{array}$ & $\begin{array}{c}\text { Mexico } \\
2010\end{array}$ & $\begin{array}{c}\text { Netherlands } \\
2008\end{array}$ & $\begin{array}{c}\text { New } \\
\text { Zealand } \\
2006-07\end{array}$ & $\begin{array}{c}\text { Slovenia } \\
2008\end{array}$ & $\begin{array}{c}\text { United } \\
\text { States } \\
2010\end{array}$ \\
\hline & \multicolumn{8}{|c|}{ Main Source of Income } \\
\hline Wages and salaries & 1.0 & & 1.0 & 1.0 & 1.0 & 1.0 & 1.1 & 1.0 \\
\hline Income from self-employment & 1.8 & & 1.0 & 0.9 & 1.3 & 1.1 & 0.8 & 0.9 \\
\hline Property income & 0.8 & & 1.0 & 2.1 & 1.1 & 1.3 & 1.1 & 2.1 \\
\hline \multirow[t]{2}{*}{ Transfers and others } & 0.9 & & 0.8 & 0.8 & 0.9 & 0.8 & 0.9 & 0.9 \\
\hline & \multicolumn{8}{|c|}{ Household Type } \\
\hline Single under 65 & 0.9 & 1.2 & 0.9 & 1.8 & 0.9 & 1.0 & 1.5 & 1.0 \\
\hline Single 65 and over & 0.9 & 0.8 & 0.6 & 0.9 & 1.0 & 0.9 & 1.0 & 0.9 \\
\hline Single with children living at home & 1.1 & 1.1 & 1.2 & 0.9 & 0.9 & 0.8 & 1.2 & 0.9 \\
\hline Two adults under 65 no child living at home & 1.1 & 1.1 & 1.0 & 1.5 & 1.1 & 1.2 & 1.3 & 1.1 \\
\hline Two adults at least one 65 and over no child living at home & 1.0 & 1.2 & 0.7 & 1.0 & 1.0 & 1.1 & 0.9 & 1.1 \\
\hline Two adults with less than 3 children living at home & 1.1 & 1.2 & 1.1 & 1.1 & 1.0 & 1.0 & 1.3 & 1.1 \\
\hline Two adults with at least 3 children living at home & 1.0 & 1.6 & 1.1 & 0.8 & 1.0 & 0.8 & 1.0 & 1.0 \\
\hline Others & 0.8 & 0.6 & 0.9 & 0.9 & 0.9 & 0.9 & 0.5 & 0.8 \\
\hline
\end{tabular}

Note: In France, the actual final consumption per consumption unit of the households for which the main source of income are wages and salaries is on average equal to the average per consumption unit actual final consumption in the country.

97. Ratio highest to lowest - The richest households show a level of consumption which is 4.0 times higher than the level of consumption of the poorest households in Mexico, as compared to 1.3 in Slovenia (Figure 10). The ratio of the highest to lowest ratio measured on consumption expenditures, excluding Social Transfers in Kind, show higher consumption inequalities, especially in France where including Social Transfers in Kind reduces the inequality ratio between the richest and the poorest by more than one point.

Figure 10: Relative position of the $20 \%$ richest households to the $20 \%$ poorest households

Final consumption expenditure and Actual final consumption, per consumption unit

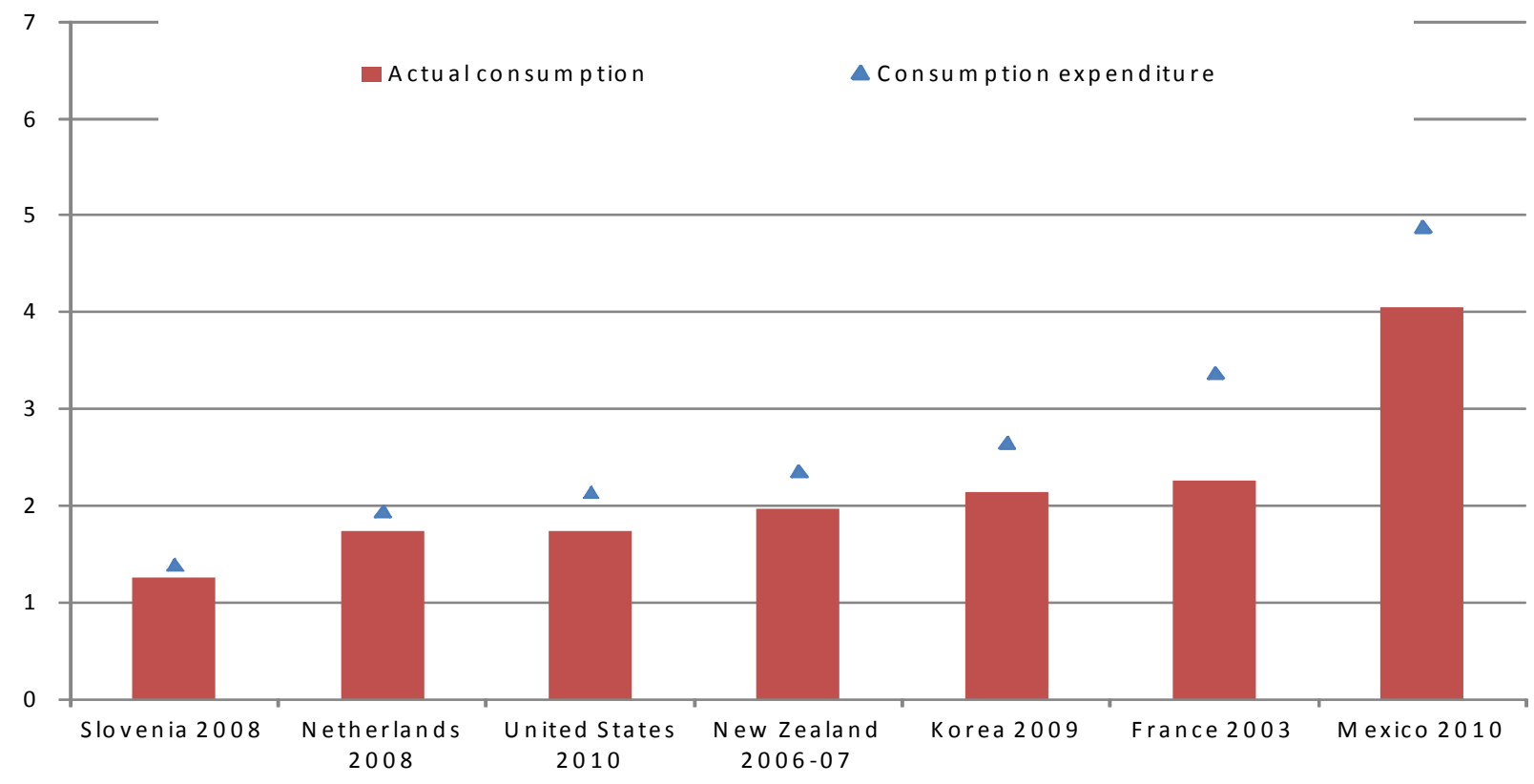


98. Disparity index - As stated before, the disparity index shows how much dispersion exists from the average across all household groups for each classification variable:

- The income quintile classification presents the highest level of disparity and heterogeneity for actual final consumption across countries: the disparity index ranks from $9 \%$ in Slovenia to $29 \%$ in France and 52\% in Mexico (Figure 11). Consumption disparity is 5.8 times higher in Mexico (3.2 in France) than in Slovenia.

- The Main Source of income classification is the household grouping showing the lowest levels of disparity and heterogeneity: the disparity index goes from $9 \%$ in Korea and in the Netherlands to $22 \%$ in Mexico.

- The Household Type classification also shows relatively high disparities in consumption and heterogeneity across countries: consumption disparity is 3.7 times higher in Slovenia than in the Netherlands; with disparity indexes of respectively $33 \%$ and $9 \%$ for these two countries.

\section{Figure 11 - Consumption disparity index for the three household classifications}

Actual final consumption per consumption unit

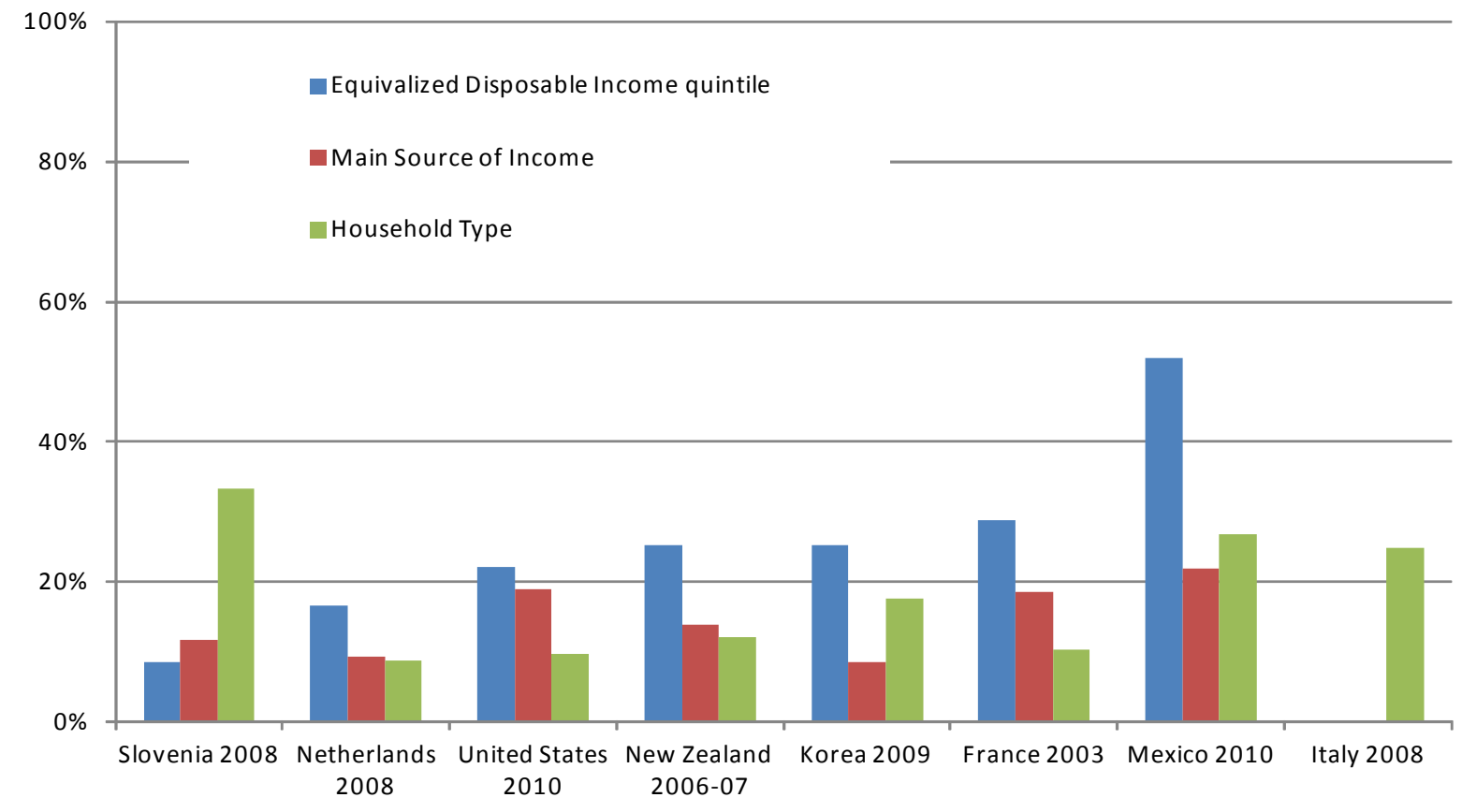

D. Income and consumption combined

99. This subsection presents results combining income and consumption components. First, a comparison between income and consumption disparities is shown for the three household classifications. Then results are detailed by Equivalized Disposable Income quintile for several ratios: saving to income, housing expenditure to income, consumption on health to income, and consumption on education to income.

\section{Comparison between income and consumption disparities}

100. Disparities are higher for income than for consumption in all countries for the two household classification based on income (i.e., Equivalized Disposable Income quintiles and Main Source of Income). 
Disparities on income are more than 1.5 times higher when classifying households according to their income quintile except in France, Sweden and Korea (Figure 12). The Household Type classification shows differences across countries: some countries have consumption inequalities higher than income inequalities, e.g., Slovenia, and some countries have consumption inequalities lower than income inequalities, e.g., the Netherlands.

\section{Figure 12: Income disparity index to consumption disparity index, by household grouping}

Disparity index on adjusted disposable income and actual final consumption, per consumption unit

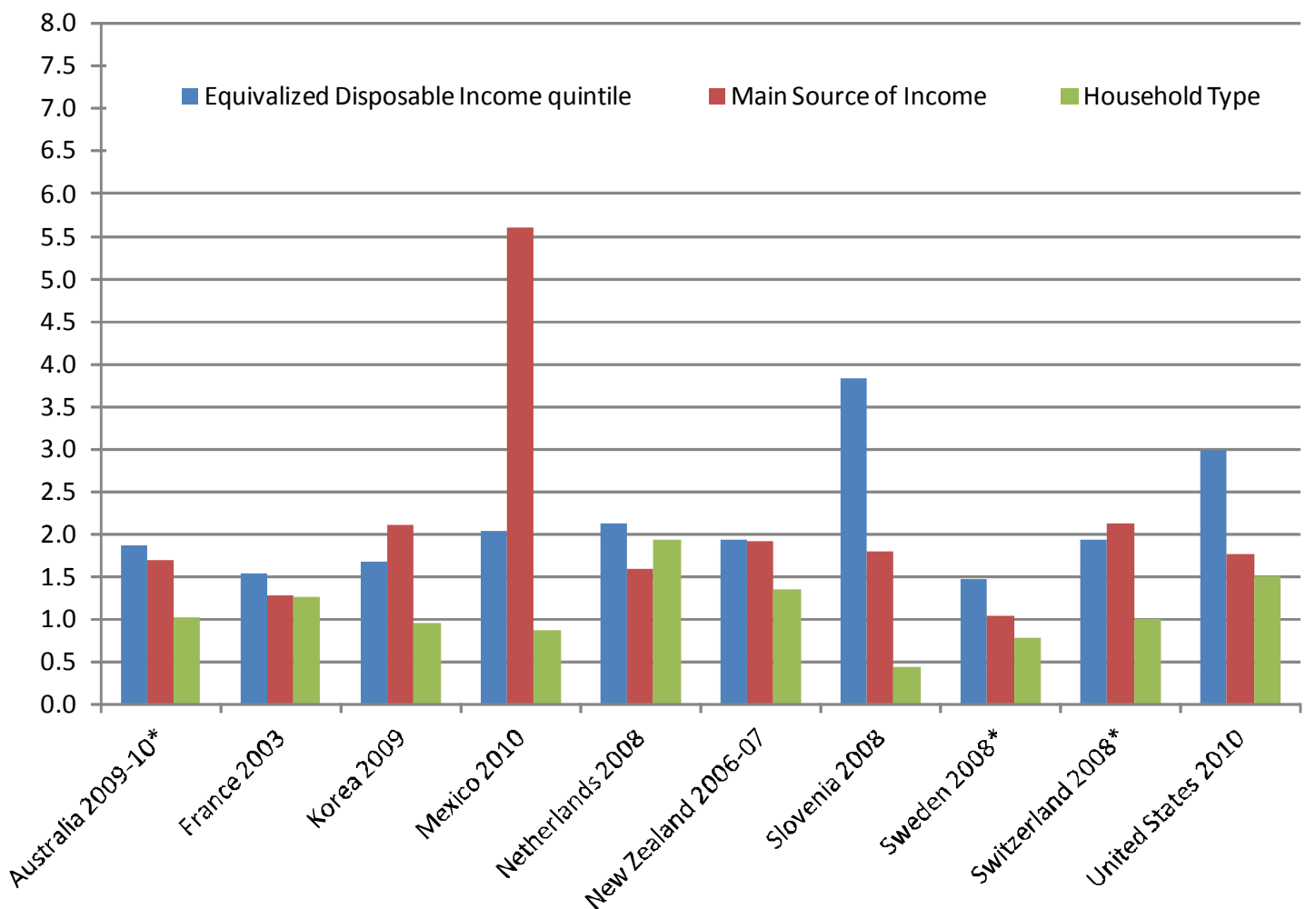

* Disparity index measured on alternative concepts: for Australia and Sweden calculation on per household adjusted disposable income and actual final consumption; for Switzerland calculation on per consumption unit disposable income and consumption expenditures.

101. One methodological issue should be reminded when combining income and consumption results. Most countries have used one micro source to split national accounts income totals by component, and another micro source to split national accounts expenditures totals by component. Inconsistencies between the two micro sources, e.g., in the way households are classified between groups, may lead to inconsistencies in results combining income and consumption (see part II.C).

\section{Saving rate}

102. Saving is the difference between adjusted disposable income and actual consumption plus the change in net equity of households in pension funds. The adjustment for net equity in pension funds is necessary because of the way contributions paid to pension funds and pension benefits received from these funds, are treated in national accounts. They are recorded as current expenditure/income, while on the other hand they are also considered as a kind of (dis)saving, adding to the value of pension entitlements. To include both views on pensions, the income point of view and the wealth point of view, and to bridge them, an adjustment had to be introduced. This dual treatment concerns employment-related pension 
schemes. It is not relevant for individual life insurance schemes, for which neither the contributions nor the benefits are recorded as current expenditure/income; they are only recorded as a financial transaction.

103. Among the countries studied the average saving rate across all households ranks from minus $3 \%$ in New Zealand in 2006-07 to 16\% in Australia in 2011-12. New Zealand is the only country showing a negative saving rate for the household population as a whole. In all countries, saving is highly concentrated on the top of the distribution. Saving as a percentage of adjusted disposable income clearly increases with income (Figure 13). In the United States and Mexico, the richest households, on average, save more than $40 \%$ of their annual adjusted disposable income. At the bottom end of the income scale, the poorest households are dissaving, i.e. on average a poor household consumes more than its annual income during the year.

\section{Figure 13 - Saving as a percentage of adjusted disposable income by Equivalized Disposable Income quintile}

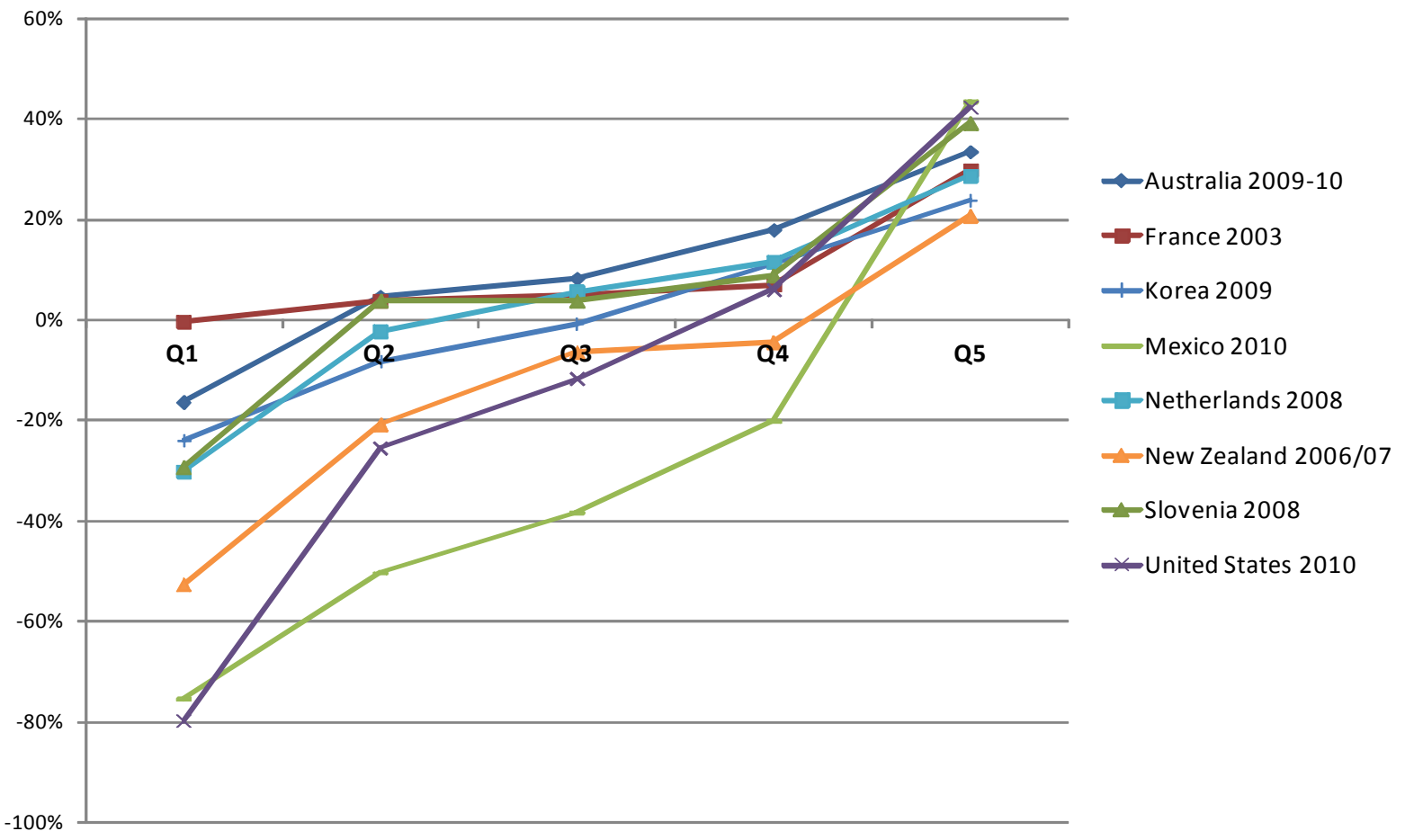

104. Negative saving rates are shown for the poorest households in all countries except France. It should be underlined however, that prior to the use of the household budget survey to distribute the national accounts totals, the French experts corrected the micro data. Thus, the income level of the households who declared to consume much more than their earnings and who declared having no financial difficulty were corrected to ensure that their income level covers their level of expenditures. Without this correction on the micro data the average saving rate of the first quintile would be negative (see Fesseau M. and Le Laidier S. (2010)).

105. Consuming more than the income received in a given year does not necessarily means that households increase their debt. They may, for instance, use financial assets accumulated in previous years to finance their annual consumption. Also, a negative saving rate for a given quintile does not necessarily mean that each household that belongs to the quintile has a negative saving rate since the saving rate is an average for the quintile. Lastly, it should be mentioned that the above estimates do not take into accounts transfers between households. Traditionally the national accounts do not take into account the income 
flows received and paid among households. Indeed, because the preliminary focus of national accounts is to study households as a whole, these income flows are generally not estimated. Australia, France, Korea, the Netherlands and the United States made saving rate estimates including transfers between households. To produce estimates for these transfers, experts used micro sources to estimate both the totals of transfers between households received/paid and the distribution of these transfers among household groups. Results show no significant impact on saving rates. Further investigations and harmonization on how to estimate these transfers may be needed.

106. The saving rates are negative beyond the first quintile in Mexico, the United States, New Zealand, Korea and in the Netherlands. This result is expected in New Zealand that shows at the aggregate level a negative saving rate (minus 3\% in 2006-07). For the other countries, this result may be surprising and should be interpreted with caution.

107. Two methodological issues may explain the above results: i) the possible inconsistencies between income and consumption micro sources used (see II.C) and ii) the difficulty in estimating the level of transfers between households. Three countries among the ones shown in Figure 13, however, used a single micro source for income and consumption components, namely Korea, New Zealand, and Mexico. Despite the above mentioned caveats these results clearly show that saving is unevenly distributed across households.

\section{Housing expenditures as a share of disposable income}

108. Housing expenditures in national accounts include actual and imputed rentals for housing, expenditure for maintenance and repair of the dwelling, water supply, and for electricity, gas and other fuels. They do not include interest payments and repayments on mortgage loans. Following this definition, Figure 14 shows that the share of housing expenditures in household disposable income has a negative correlation with income quintile except in France that shows a flat distribution from the first to the fourth quintile. Across countries the share of housing expenditures in income for the poorest households is $24 \%$ in France, as compared to $62 \%$ in New Zealand. The richest households have a lower share of housing expenditures from 9\% in Mexico to $17 \%$ in Switzerland and France.

109. Further analysis on how countries treat housing subsidies may be needed however. Indeed, in the United States, household expenditures include subsidies with the great majority of these subsidies provided to the lowest quintile. Instead, in France, housing subsidies are recorded as Social Transfers in Kind. Such cross country differences may distort the comparison. To avoid such distortion the ratio to be preferred would be housing consumption (including STiK for housing) as a share of adjusted disposable income (including STiK). Unfortunately, the STiK sub-component related to housing is not isolated in the Expert group template. 
Figure 14: Housing expenditure as a share of disposable income

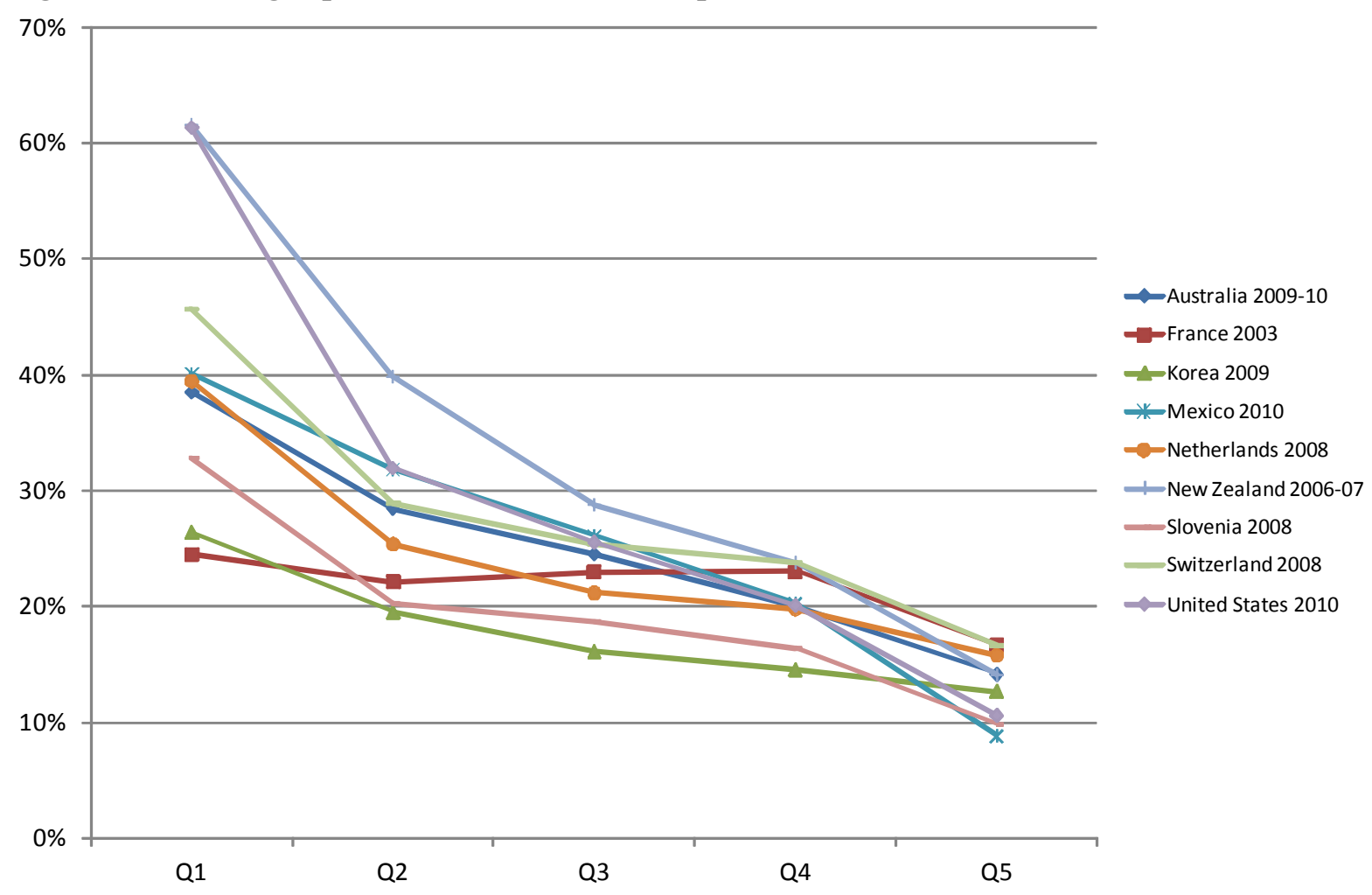

Health consumption as a share of adjusted disposable income

110. Health consumption covers household expenditures for outpatient and hospital services, for medical products, appliances and equipment, and also Social Transfers in Kind that households receive from government to cover their health care needs. Overall, the share of health consumption in adjusted disposable income is decreasing with income (Figure15). Across countries the share for health consumption in income for the poorest households is $14 \%$ in the Netherlands, as compared to $37 \%$ in the United States. The richest households consume on average 4\% of their adjusted disposable income on health in Mexico, versus 9\% in the United States. Overall, the United States shows a rather high share of income devoted to health consumption whatever the quintile. This may be explained by relatively high prices for health services. 
Figure 15: Health consumption as a share of adjusted disposable income

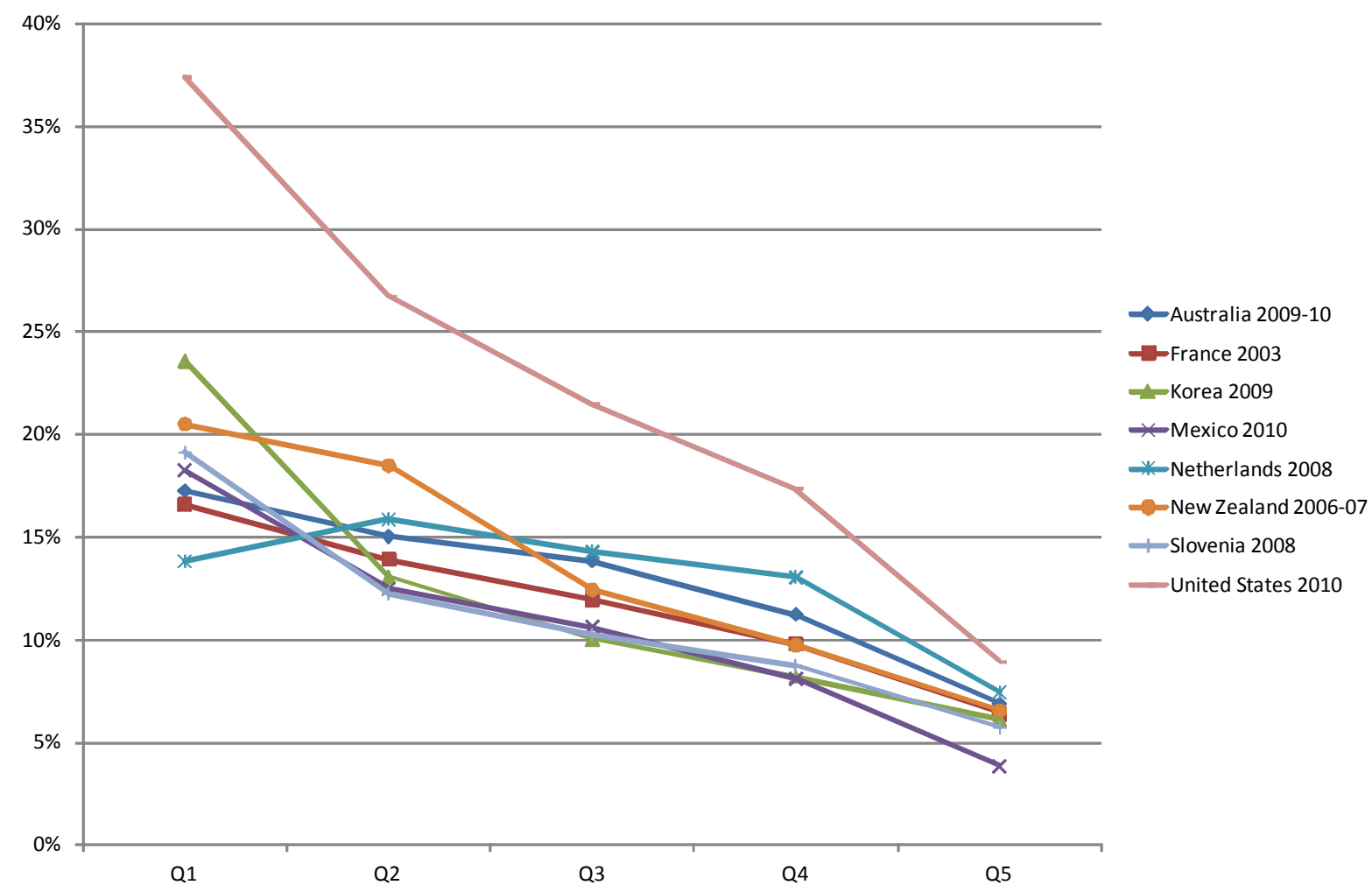

Education consumption as a share of adjusted disposable income

111. Education consumption covers household expenditures for education, and also Social Transfers in Kind that households receive from government to cover their education needs. Overall, the share of education consumption in adjusted disposable income is decreasing with income (Figure16). Across countries the share for education consumption in income for the poorest households is $11 \%$ in Korea, as compared to $25 \%$ in Mexico. The richest households consume on average 3\% to $4 \%$ of their adjusted disposable income on education in all the countries studied except in Korea where the share is twice higher $(8 \%)$. Overall, Korea shows a very different pattern compared to the other countries. 
Figure 16: Education consumption as a share of adjusted disposable income

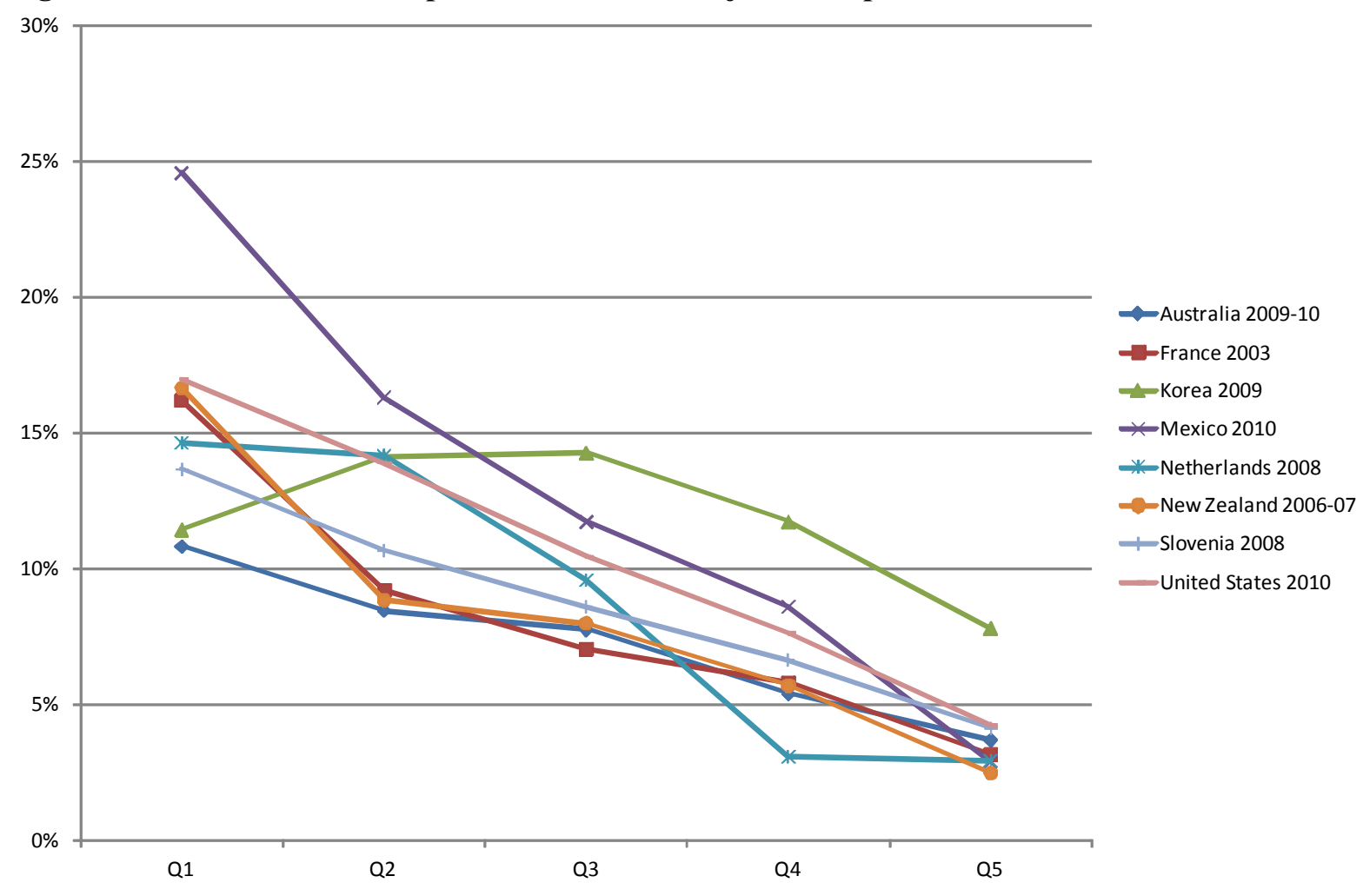

\section{E. Impact analysis and comparisons}

112. This subsection first analyses the impact of adhering to the national accounts concepts and definitions. Subsequently, the subsection presents a comparison between the Expert group results and other information on income disparities coming from the OECD database on income distribution, and those from a Eurostat study, the a-minima exercise, conducted in parallel to the Expert group's work.

\section{Adhering to national accounts concepts and definitions}

113. The income and consumption aggregates analyzed in this study follow the national accounts definitions that include some imputations. The main imputations that are part of adjusted disposable income relate to Social Transfers in Kind, operating surplus from owner occupied dwellings, property income attributed to insurance policy holders, and financial intermediation services indirectly measured (FISIM). The main imputations included in actual final consumption are Social Transfers in Kind, imputed rentals for housing, and FISIM (Annex 1).

114. Overall, the introduction of the above national accounts concepts has the highest impact on income disparity when households are classified by Equivalized disposable income quintiles (Table 15). Sweden and the United States show the highest impact on the disparity index (a reduction by respectively 22 and 20 points).

115. The introduction of the national accounts concepts also significantly affects the richest to poorest ratio, in particular when measured on income. The richest to poorest ratio is reduced by more than 1 point in most countries. Mexico shows the largest reduction ( 9.6 points) followed by the United States ( 8.1 points). As illustrated in Figure 17 for adjusted disposable income, a major part of the reduction is explained by Social Transfers in Kind (Figure 17). 
Table 15 - Impact of introducing national accounts concepts

Per household income and consumption measures

\begin{tabular}{|c|c|c|c|c|c|}
\hline & & \multicolumn{3}{|c|}{ Disparity index } & \multirow{2}{*}{$\begin{array}{c}\begin{array}{c}\text { Ratio highest to } \\
\text { lowest }\end{array} \\
\text { Q5/Q1 }\end{array}$} \\
\hline & & \begin{tabular}{|c} 
Equivalized \\
Disposable Income \\
quintile
\end{tabular} & $\begin{array}{l}\text { Main Source } \\
\text { of Income }\end{array}$ & $\begin{array}{l}\text { Household } \\
\text { type }\end{array}$ & \\
\hline \multirow{14}{*}{$\begin{array}{l}\stackrel{0}{\tilde{o}} \\
\underline{0}\end{array}$} & Australia 2009-10 & $-11 \%$ & $-10 \%$ & $0 \%$ & -1.2 \\
\hline & France $2003^{*}$ & $-10 \%$ & $-7 \%$ & $-1 \%$ & -1.5 \\
\hline & Germany 2008* & $-2 \%$ & $-3 \%$ & $1 \%$ & -0.2 \\
\hline & Italy 2008 & $-15 \%$ & $-6 \%$ & $-2 \%$ & -3.1 \\
\hline & Japan 2009 & & $-11 \%$ & $-2 \%$ & \\
\hline & Korea 2009 & $-9 \%$ & $-4 \%$ & $0 \%$ & -1.6 \\
\hline & Mexico 2008 & $-14 \%$ & $-23 \%$ & $-1 \%$ & -7.6 \\
\hline & Mexico 2010 & $-15 \%$ & $-25 \%$ & $0 \%$ & -9.6 \\
\hline & Netherlands 2008 & $-10 \%$ & $-10 \%$ & $2 \%$ & -0.7 \\
\hline & New Zealand 2006-07 & $-19 \%$ & $-9 \%$ & $-4 \%$ & -3.6 \\
\hline & Slovenia 2008 & $-12 \%$ & $-5 \%$ & $-2 \%$ & -1.8 \\
\hline & Sweden $2008^{*}$ & $-22 \%$ & $-8 \%$ & $1 \%$ & -4.1 \\
\hline & Switzerland $2008^{*}$ & $0 \%$ & $4 \%$ & $0 \%$ & 0.0 \\
\hline & United States 2010 & $-20 \%$ & $-9 \%$ & $0 \%$ & -8.1 \\
\hline \multirow{15}{*}{ 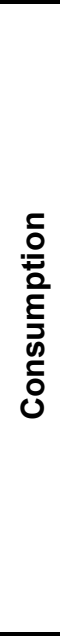 } & Australia 2009-10 & $-12 \%$ & $-11 \%$ & $-3 \%$ & -0.6 \\
\hline & France $2003^{*}$ & $-7 \%$ & $-9 \%$ & $2 \%$ & -0.8 \\
\hline & Israel 2009* & $-11 \%$ & $-4 \%$ & $2 \%$ & -0.9 \\
\hline & Italy 2008 & & & $0 \%$ & \\
\hline & Korea 2009 & $-5 \%$ & $-2 \%$ & $2 \%$ & -0.5 \\
\hline & Mexico 2008 & $-5 \%$ & $-3 \%$ & $0 \%$ & -0.6 \\
\hline & Mexico 2010 & $-5 \%$ & $-3 \%$ & $0 \%$ & -0.7 \\
\hline & Netherlands 2008 & $-2 \%$ & $5 \%$ & $7 \%$ & 0.0 \\
\hline & New Zealand 2006-07 & $-9 \%$ & $-7 \%$ & $-6 \%$ & -0.5 \\
\hline & Portugal 2006* & $0 \%$ & $-1 \%$ & $-1 \%$ & 0.1 \\
\hline & Slovenia 2008 & $-5 \%$ & $-2 \%$ & $-3 \%$ & -0.2 \\
\hline & Sweden $2008^{*}$ & $-11 \%$ & $-13 \%$ & $-10 \%$ & -0.8 \\
\hline & \begin{tabular}{|l} 
Switzerland $2008^{*}$ \\
\end{tabular} & $2 \%$ & $2 \%$ & $-1 \%$ & 0.1 \\
\hline & \begin{tabular}{|l} 
Turkey $2010^{*}$ \\
\end{tabular} & $-1 \%$ & $-2 \%$ & $-2 \%$ & 0.0 \\
\hline & United States 2010 & $-5 \%$ & $-8 \%$ & $1 \%$ & -0.3 \\
\hline
\end{tabular}

* Country not fully comparable with the others because the micro income variables were not benchmarked to national accounts totals prior to the classification of households or because the concepts studied exclude STiK and/or FISIM. 
Figure 17 - Impact of introducing national accounts concepts on the richest to poorest ratio Per household adjusted disposable income

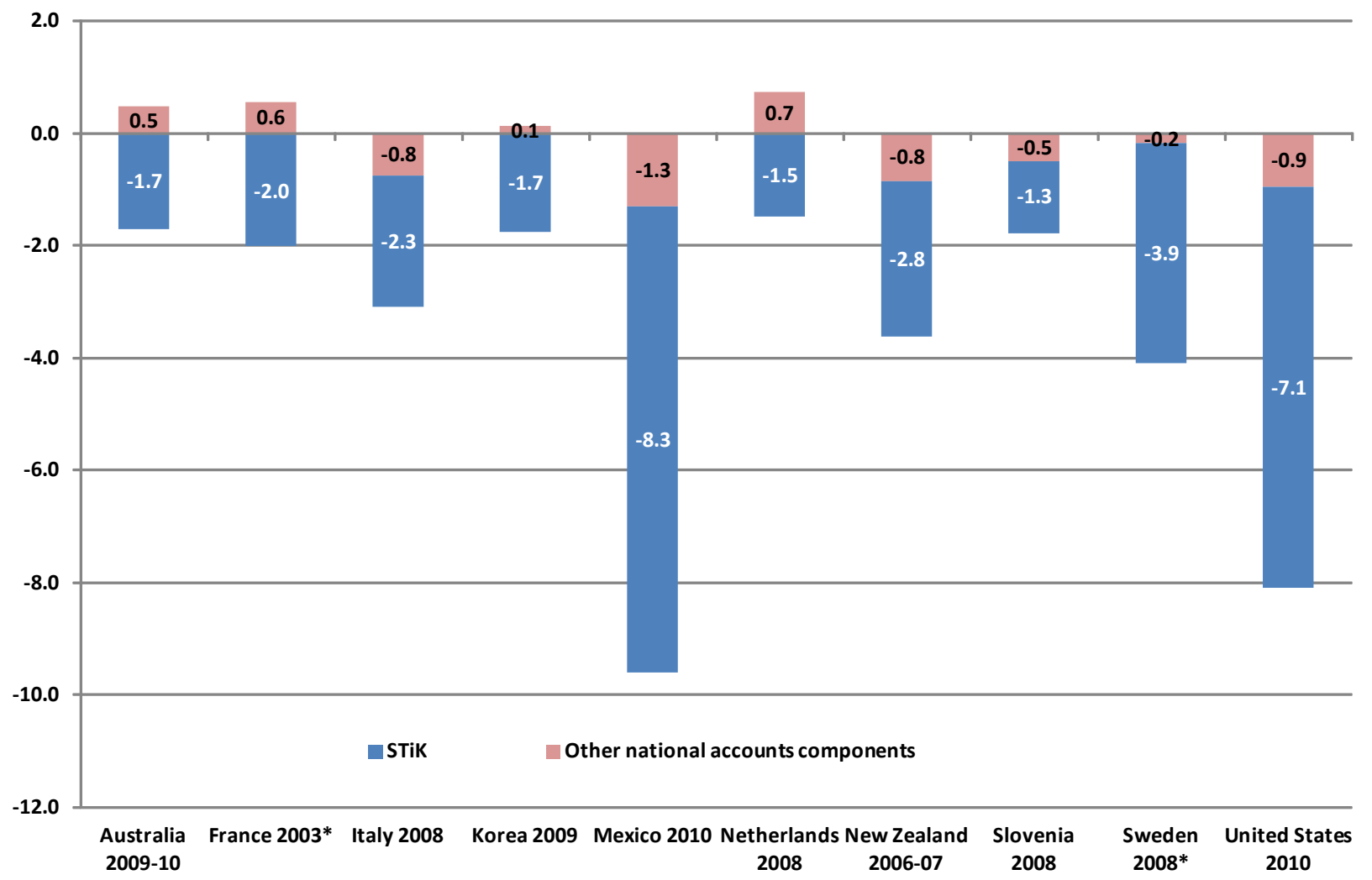

* Country not fully comparable with the others because the micro income variables were not benchmarked to national accounts totals prior to the classification of households (Sweden) or because the concepts studied exclude FISIM (France).

\section{Check with other results on income disparity}

116. OECD Income Distribution Database (IDD) - The IDD provides comparable set of data on income distribution of households across OECD countries. This database relies entirely on micro sources, mainly household surveys. The comparison of the richest quintile to the poorest quintile between the IDD and the Expert Group results shows, in some cases quite substantial, differences (Figure 18). The following factors for divergences can be identified:

- Micro source used: for a given country, the micro source used for the IDD may be different from the one used by national experts as part of the Expert group's work;

- Year: the IDD does not provide annual data due to lack of data availability, as a consequence of which the comparison cannot be performed for the same year;

- Income definition: the Expert Group income analysis includes some national accounts components that are not part of the IDD micro income definition such as Social Transfers in Kind and income from owner-occupied dwellings;

- Individuals versus households: the IDD indicators analyze individuals. Each individual is given the equivalized income of his/her household. Instead, the Expert Group analyzes households. If the poorest are larger households than the other households, the first quintile in the Expert Group's study will include more than $20 \%$ individuals; 
- Benchmarking to national accounts totals (step 3 and 4): some income components, such as income from self-employment and property income, show significant gaps between micro totals and national accounts totals; benchmarking the distributional information on national accounts totals may impact the final distribution if these are unevenly distributed amongst households (Annex 6).

117. Figure 18 shows a comparison for the poorest to richest ratio between the IDD and several measures from the Expert Group work. The Expert Group measures diverge depending on whether or not national accounts concepts (namely, FISIM, STiK, income from owner-occupied dwellings and property income attributed to insurance policy holders) are fully adhered to.

118. For all countries except Mexico the Expert Group estimates show household income disparities that are lower than those in the IDD. This is mainly explained by the inclusion of Social Transfers in Kind in the national account definition. The particular case of Mexico can be explained by the low share of STiK in total adjusted disposable income and by the benchmark procedure which significantly affect the results for Mexico (Annex 6).

119. Once the national accounts concepts are excluded, the inequality between the poorest and the lowest are higher in the Expert Group's results, with the exception of the Netherlands and Korea. The gap between the results of this study and the IDD estimates is particularly high for the United States. Showing higher inequality in the Expert Group work than in the IDD is logical. Indeed, the benchmarking procedure gives more importance to the income components that show big gaps between micro and macro totals. Some of the major components showing a large gap, such as interests and dividends received, are components that are unequally distributed among households; giving them more importance increases the inequality ratio. In the case of the United States both the IDD and the Expert Group estimates are based on the Current Population Survey (CPS). As part of the Expert Group exercise, however, the CPS data were supplemented by information from income tax records for the highest income not believed to be captured in CPS. These households account for significant shares of self-employment income and property income, and widened the rich to poor ratio that result from the CPS data when used alone.

\section{Figure 18 - Richest to poorest ratio - comparison between the IDD and the Expert Group results}

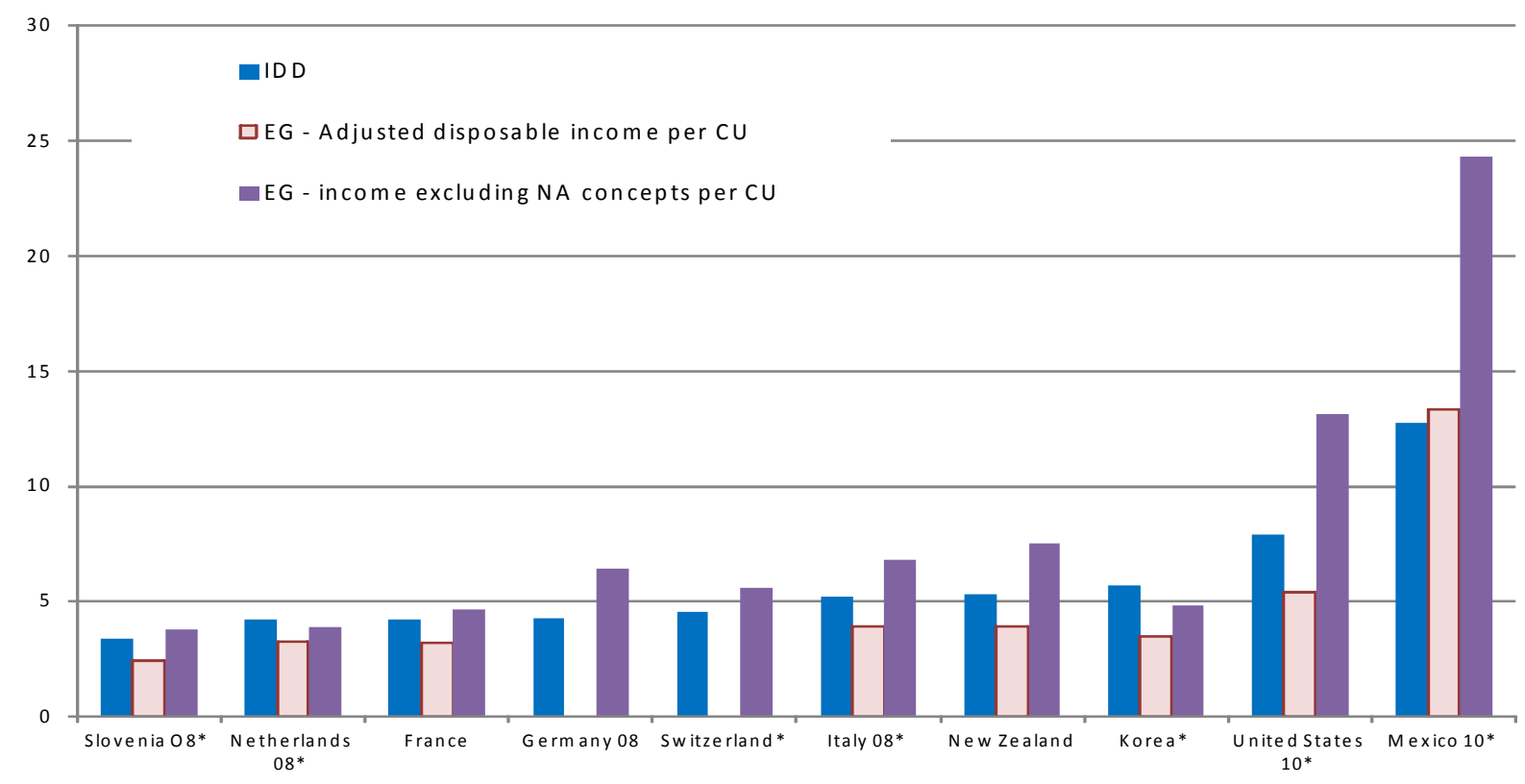

Note: The legend indicates the extent to which the IDD and the Expert Group results are comparable. A star indicates similar micro sources. The 2 figures year is indicated in case of similar year for IDD and the Expert Group. 


\section{Eurostat a- minima exercise}

120. In parallel to the Expert Group work, Eurostat launched a similar study, called a-minima exercise because dealing with a limited set of information in respect to the EGDNA. Actually, as the priority was the harmonization across EU of micro data sources, it made use of European Union Survey on Income and Living Conditions (EU-SILC) ${ }^{20}$, which is available for all the EU27 countries and for most of the EFTA countries. With respect to the methodology, Eurostat followed as far as possible the Expert Group's decisions on methodological choices allowing a comparison of the results.

121. The comparison between the Expert Group results and the a-minima exercise has been done for disposable income per consumption unit, and covers six countries: Switzerland, Germany, France, Italy, the Netherlands and Slovenia ${ }^{21}$. Despite the effort of harmonization between the Expert Group work and the a-minima exercise, several reasons may explain gaps between the two studies:

- Micro source used: as part of the Expert Group's work national experts, taking advantage of the richer datasets available at the national level, may not use the EU-SILC survey to breakdown (part of) the relevant national accounts totals by household group. This is the case for example for, the Household Budget Survey in Germany, the Income Panel Survey in the Netherlands, and the Tax Income survey in France;

- Year: national experts were asked to compile data, to the extent possible, for the same year. a-minima; Among the six countries all but France measured disparity for 2008;

- Level of detail for the breakdown: the breakdown by national experts is more detailed using a higher number of income components than in the case of the a-minima exercise;

- Procedure used to grouping by income: the a-minima departed from the Expert Group when specific income micro variables were missing like interests paid needed to build the net property income in main source of income classification;

- The reference demographic series: the a-minima exercise used directly the number of households of the EU-SILC dataset, while EG members adopted generally another source for this information;

- Transfers between households: the a-minima exercise included in its calculation this income component whereas among the 6 countries studied only France and the Netherlands did.

122. Overall, the cross country results are rather similar for the two studies (Table 18). In both studies the two income groupings show higher disparity than the Household Type grouping. The Expert group results tend, however, to show higher levels of disparity for the variable main source of income. In particular, France shows higher disparities than the a-minima exercise for the three disparity indexes and for the rich to poor ratio. As stated previously, however, France data refer to year 2003 while the a-minima estimates relate to 2008 .

\footnotetext{
$20 \quad$ Eurostat (forthcoming 2013).
}

21 Eight European countries involved in the Expert Group produced estimates on income. The comparison is however performed on a reduced number of countries and on the disposable income rather than on the adjusted disposable income because not all European countries filled out the full Expert Group template (e.g., as part of the Expert Group work Switzerland and Germany do not include the Social Transfers in kind component and Sweden does not estimate per consumption unit). 
Table 18 - Comparison between the Expert Group and the a-minima results

Disposable income per consumption unit

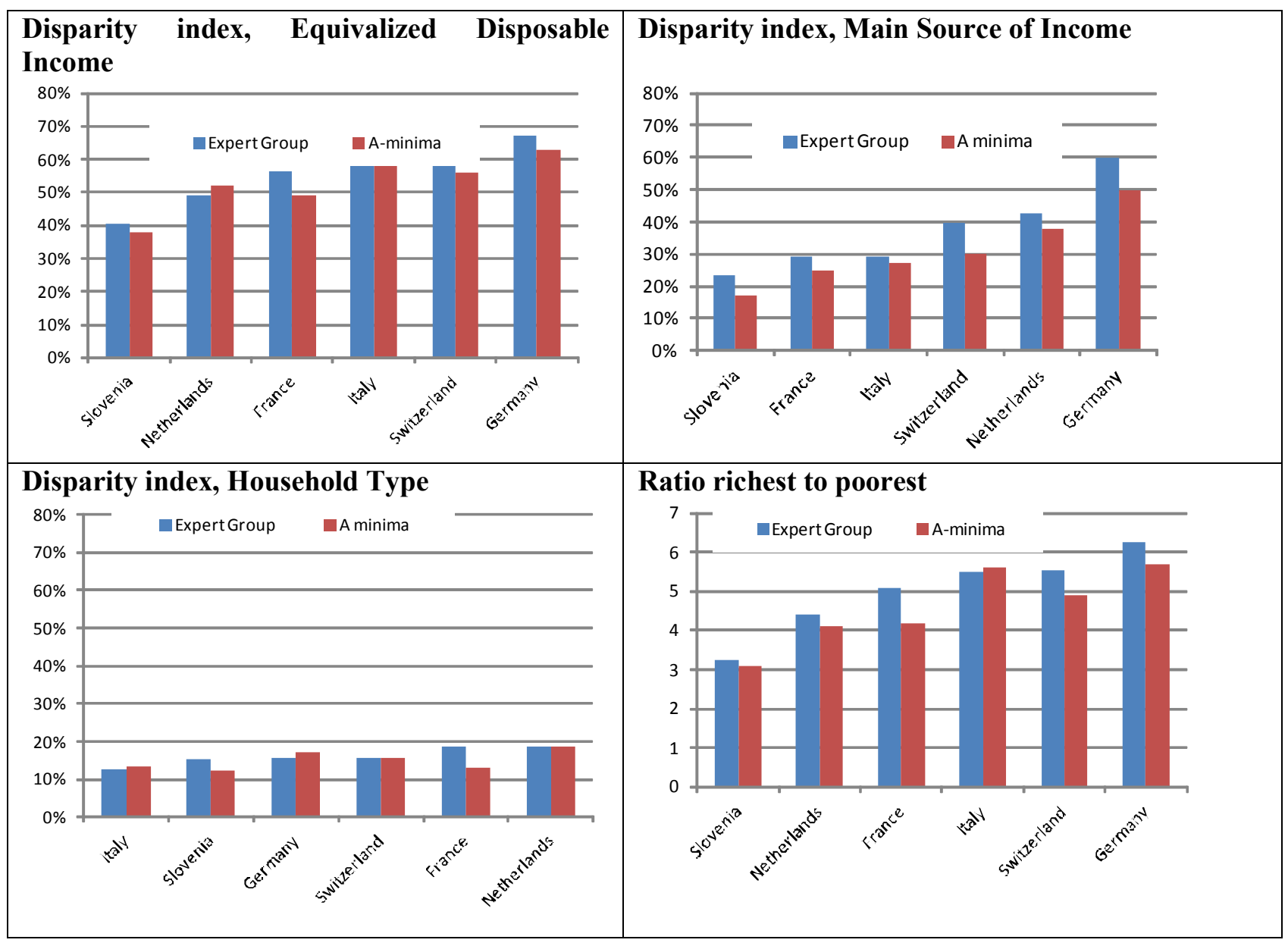

\section{Conclusions and way forward}

123. The analysis of disparities in household income, consumption and saving presented in this paper is based on the work done by national experts, under the umbrella of the OECD-Eurostat Expert Group on measuring disparities in a national accounts framework. The paper includes results that complement the description of the average household income and consumption levels, as currently available in the System of National Accounts, with consistent measures that show the extent to which households diverge from these averages. Doing so, households are broken down in subgroups based on income quintile, main source of income, and household type. The harmonized methodology and template followed by national experts allow for a cross country comparison.

124. In all countries studied, results show high income disparities across households classified according to income quintiles. Households for which property income and self-employment income are the main source of income have a significantly higher income than the average. Income disparities are higher than consumption disparities leading to even higher disparities across households for saving, in particular between the richest and the poorest households. Differences appear across countries in the extent to which the poorest and the richest households diverge from the income and saving averages. Countries also show 
differences in the extent to which the net current transfers reduce disparities between the richest and the poorest households, and between the households with members over 65 and the average household.

125. This methodological paper makes clear how a better use of existing micro sources by national accounts compilers could be used to produce more detailed national accounts data on households, and how such estimates could complement the national accounts estimates by showing distributional measures consistent with the current description of the average household. As such, the analysis can provide much better estimates on the developments of material well-being of households, and possible diverging patterns between economic growth and developments of real income and consumption for different household groups. The analysis of the gaps between micro data sources and relevant national accounts totals also helps to understand the strengths and weaknesses of both estimates and to improve them in the future.

126. The paper also illustrates that a number of assumptions is needed to produce the relevant estimates. The main methodological issues relate to the benchmarking of micro totals to national accounts totals; the imputation of distribution for imputed items such as Social Transfers in Kind; the impact of possible inconsistencies across micro sources on income and consumption; the availability of sociodemographic series on number of households and number of consumption unit by households group.

127. This working paper is published to further enhance the research on how to produce disparity measures consistent with national accounts. Further work, however, would be needed to improve the sources used and the methodology applied, and to make clear what can be expected from this type of analysis. At the micro level, working on matching techniques combining income and budget surveys prior to their use in the calculation may enhance results on saving rates. Also, producing time series of distributional indicators may help in knowing whether the method is replicable and whether a clear and undisputed analysis can be given of developments over time. Furthermore, working on the feasibility of compiling information on the distribution of wealth among household groups would allow a combined analysis of income, consumption and wealth for household groups which may also be instrumental in explaining the saving rates. 


\section{Bibliography}

CBS Statistics Netherlands (2011), National Accounts of the Netherlands 2010, p. 185-189. http://www.cbs.n1/NR/rdonlyres/233FCD1A-C2EC-42B6-BFBC4070D31DFE2B/0/NatAccErratumwebversie.pdf

Coli A. and Tartamella F. (2012) Analyzing the Distribution of Income: How to Account for the Underground Economy in the Household Income Micro Datasets. IARIW 2012 Conference. http://www.iariw.org/papers/2012/TartamellaPaper.pdf

Eurostat (forthcoming 2013), The distribution of household sector accounts by category of household Report on the European exercise.

Fesseau M. and Le Laidier S. (2010), Social Disparities Between Groups of Households Within a National Accounts Framework: A Breakdown of Household Accounts, IARIW 2010 - St Gallen, Switzerland http://www.iariw.org/papers/2010/7cFesseau.pdf

Fesseau, M., Wolff F. and Mattonetti M-L. (2013), A cross country comparison of household income, consumption and wealth between micro sources and national accounts aggregates, Working Paper $\mathrm{n}^{\circ} 52$, Paris: OECD.

IMF and FSB (International Monetary Fund and Financial and Stability Board) (2012), "The Financial Crisis and Information Gaps Progress Report on the G-20 Data Gaps Initiative: Status, Action Plans, and Timetables."

http://www.imf.org/external/np/g20/pdf/093012.pdf

OECD (2013), OECD Framework for Statistics on the Distribution of Household Income, Consumption and Wealth. Paris: OECD.

http://www.oecd.org/statistics/302013041e.pdf

Stiglitz, J.E., Sen, A. and Fitoussi, J-P. (2009), Report by the Commission on the Measurement of Economic Performance and Social Progress. The Commission: Paris. http://www.stiglitz-senfitoussi.fr/en/index.htm

Verbist, G., M. Förster and M. Vaalavuo (2012), The Impact of Publicly Provided Services on the Distribution of Resources: Review of New Results and Methods. Paris: OECD.

http://www.oecd-ilibrary.org/social-issues-migration-health/the-impact-of-publicly-provided-

services-on-the-distribution-of-resources_5k9h363c5szq-en 


\section{Annex 1 - Definition of the national accounts aggregates and components}

National accounts data provide information on various components of income flows received and paid by households (e.g. wages and salaries, social benefits, income taxes), on types of household expenditures (e.g. food, clothing, housing), and on a number of aggregates that are economically significant.

Definitions for the key aggregates are given below:

- Household primary income is what accrues to households as a consequence of their involvement in processes of production or ownership of assets that may be needed for purposes of production. Compensation of employees is a major item of primary income of households. It represents the total earnings from labor input, and includes social contributions paid by employers on behalf of their employees. Property income received and paid by lending or renting financial or natural resources, including land, to other units for use in production also affect the primary income.

- Household disposable income is derived from the primary income by adding net current transfers (i.e. social benefits in cash and other current transfers received minus social contributions and taxes paid).

- Household final consumption expenditures covers all purchases made by resident households at home or abroad to meet their everyday needs: these include purchases for food, clothing, housing services (rents), energy, transport, durable goods (notably cars), spending on health, on leisure and miscellaneous services. The reference classification used by national accounts compilers is the Classification of Individual Consumption according to Purpose (COICOP).

- Household saving represents the part of disposable income (adjusted for the change in pension entitlements $^{22}$ ) that is not spent on final consumption goods and services.

The SNA proposes an alternative concept for measuring household income and consumption that takes into account spending by general government and NPISH that benefit households. These Social Transfers in Kind (STiK) include the expenditure by general government and NPISH on the provision of various individual services (health care, education, etc.) and the reimbursement of household purchases of goods and services (such as medical consultations and medicines as well as housing rentals). The alternative national accounts aggregates are the household adjusted disposable income and the actual final consumption, which correspond, respectively, to household disposable and final consumption expenditures to which Social Transfers in Kind are added.

The income and consumption aggregates described above include some imputations. The main imputations that are part of adjusted disposable income relate to Social Transfers in Kind, operating surplus from owner occupied dwellings, property income attributed to insurance policy holders, and financial intermediation services indirectly measured (FISIM). The main imputations included in actual final consumption are Social Transfers in Kind, imputed rentals for housing, and FISIM.

The adjustment for net equity in pension funds is necessary because of the way contributions paid to pension funds and pension benefits received from these funds, are treated in national accounts. They are recorded as current expenditure/income, while on the other hand they are also considered as a kind of (dis)saving, adding to the value of pension entitlements. To include both views on pensions, the income point of view and the wealth point of view, and to bridge them, an adjustment had to be introduced. This dual treatment concerns employment-related pension schemes. It is not relevant for individual life insurance schemes, for which neither the contributions nor the benefits are recorded as current expenditure/income; they are only recorded as a financial transaction. 
Definitions for these items, based on the SNA 2008 references are given below:

- Social Transfers in Kind - These transfers consist of goods and services provided to households by government and NPISH either free or at prices that are not economically significant. Social Transfers in Kind include services such as health care, education, long-term elderly care, and childcare services. Reference: SNA 2008, chapter 8.141.

- Income from owner occupied dwellings - The SNA specifies that an imputed rental on owner occupied housing should be included in the production boundary and form part of household consumption. The whole of the imputed rental less actual costs incurred (including costs other than those relating to repairs) is treated as operating surplus of the owner. The full value of the rental is shown as consumption of owner-occupied dwellings. The same principle applies for the main residence and the houses owned as second homes. Reference: SNA2008, chapters 20.64, 24.52, 24.56.

- Property income attributed to insurance policy holders - The insurance corporation has a liability towards the policyholders and annuitants. Set against this liability, the insurance corporation holds technical reserves (non-life policies) or have funds that are invested in a range of financial assets and possibly non-financial assets (life insurance policies and annuities). The investment income on these reserves is treated as income attributable to the policyholders. For life insurance policies and annuities contracted as part of an employment-related social insurance scheme the investment income is paid back as household social contributions supplements. For non-life policies contracted, the investment income is paid back to the insurance corporation as a net non-life direct insurance premium supplement. Reference: SNA 2008, chapters 7.142 to 7.150 .

- Financial intermediation services indirectly measured (FISIM) - These financial services are an indirect measure of the value of financial intermediation services provided but for which financial institutions do not charge explicitly. Financial institutions provide services and charge for them. The ways in which they charge, however, are not always obvious. When a bank offers "free banking" it only signifies that there are no explicit fees, not that there are no implicit fees. Fees may be charged indirectly by means of charging those purchasing a financial asset more than the seller of the same asset receives. The amount of interest payable on loans and of interest received by households includes a margin that represents an implicit payment for the services provided by the financial corporations in providing loans and accepting deposits. The actual payments or receipts to or from financial corporations, described as bank interest, need to be partitioned so that SNA interest and the service charges may be recorded separately. The amount of SNA interest paid by borrowers to financial corporations is less than bank interest by the estimated value of the charges payable, while the amount of SNA interest receivable by depositors is higher than bank interest by the amount of the service charge payable. Reference: SNA 2008, chapters 7.116 and 17.230. 


\section{Annex 2 - Expert Group template: household groups}

The breakdown of the household accounts consisted of allocating the national accounts totals in sub-totals by household groups for the three following criteria:

- Equivalized household disposable income quintile (EDI): Households are classified according to the level of their equivalized disposable income. The Oxford-modified equivalence scale (also called the OECD-modified scale) is used to equivalize the disposable income. This scale assigns a value of 1 to the household head, of 0.5 to each additional adult member - aged 14 or over - and of 0.3 to each child - below 14. Households were ranked according to the value of the equivalized disposable income and allocated to five equal groups (quintiles), each of them containing $20 \%$ of all households.

- Main source of income (MSI): Households are classified according to the main source of income for the household as a whole. The four income sources identified are wages and salaries, income from self-employment, net property income ${ }^{23}$, and current transfers received.

- Household type (HT): Households are classified according to three criteria: the number of adults in the household; the age of the adults; and the presence of children living at home ${ }^{24}$. Eight household subgroups are distinguished: a) single person under the age 65 ; b) single person aged 65 and over; c) one adult with children living at home, whatever the age of the adult; d) two adults both under the age of 65 and without children living at home; e) two adults with at least one aged 65 and over, and without children living at home; f) two adults with less than three children living at home whatever the age of the adults; g) Two adults with at least three children living at home whatever the age of the adults; $h$ ) and other household types. The latter group includes households with more than two adults such as households where grandparents live with their children and grandchildren.

For the three household classifications the household as a whole is the unit of grouping; the household being defined as people living in the same dwelling and having a common budget.

This annex defines the "micro cash disposable income" concept used for the two income classifications namely EDI and MSI. Then, it gives detail about how households are classified between the eight groups for the household type classification.

\section{Definition of the micro cash disposable income}

The two income classifications (EDI, MSI) are based on a classification of households according to a cash or near cash disposable income concept which excludes thenet value of owner-occupied housing services, Social Transfers in Kind, imputed property income such as investment income earned by insurance policy holders, and financial intermediation services indirectly measured (FISIM). These items were excluded to be closer to users' perception and because they may not be available at the micro level. As a consequence, the income variable used to classify households is not fully consistent with national accounts definitions.

To the extent possible, variables used in building up the income classification variables as part of the Expert Group work follow the definitions adopted by the "Canberra Group on household income statistics" ${ }^{\prime 25}$ that are reminded in the table below.

\footnotetext{
23 Net refers here to property income received minus property income paid.

24 Both individuals under the age 16, and individuals aged between 16 and under 25 and who are offspring of one member of the households are considered as children living at home. 
Table 1 - Micro cash disposable income, definition

\section{Wages and salaries}

It consists of payments, in cash or in kind, received by individuals as results of their involvement in paid jobs.

It includes direct wages and salaries for time worked and work done, cash bonuses and gratuities, commissions and tips, directors' fees, profit-sharing bonuses and other forms of profit related pay, remuneration for time not worked such as for annual leave, holidays or other paid leave, share entitlements, free or subsidized goods and services from an employer. It also includes severance and termination pay.

It excludes social insurance contributions made by employers to secure social benefits for their employees.

2 Income from self-employment

Income from self-employment is income received by individuals as a result of their involvement in self-employment jobs. Net income from self-employment includes the profit or loss that accrues to owners of, or partners in, unincorporated enterprises who work in these enterprises.

The basis for the measurement of income from self-employment in household income statistics is the concept of 'net' income, that is, the value of gross output less operating costs (including interest and dividends paid) and after adjustment for depreciation of assets used in production.

It excludes profits or losses from the capital investment of partners who do not work in these enterprises ('silent' partners) which are included in property income.

It includes the estimated value of goods and services produced for barter, as well as goods produced for own consumption, less expenses.

3 Property income (net, received minus paid)

Property income is defined as receipts that arise from the ownership of assets (return for use of assets) provided to others for their use. They comprise returns, usually monetary, from financial assets (interest, dividends), from non-financial assets (rent) and from royalties (return for services of patented or copyrighted material).

- Interest receipts are payments received from accounts with banks, building societies, credit unions and other financial institutions, certificates of deposit, government bonds/loans, securities, debentures and loans to non-household members. - Dividends are receipts from investment in an enterprise in which the investor does not work. This includes 'silent' partners. Pensions and annuities in the form of dividends from voluntary private insurance schemes are also included. Dividends should be recorded net of any expenses incurred in earning them, including interest paid. It excludes withdrawals of income from a quasi-corporation that are treated as income from self-employment.

- Rents are payments received for the use of both unproduced assets (i.e. natural resources), such as land, and for produced assets, such as houses. Rents should be recorded net of any expenses incurred in earning them, including interest paid.

- Royalties are receipts arising from the return for services of patented or copyright material, e.g. receipts from writings, right to make use of inventions, etc.

4 Current transfers received

Transfers are receipts for which the recipient does not provide anything to the donor in direct return for the receipts. Transfers can consist of cash (in the monetary sense), of goods, or of services. Transfers may be made between households, between households and government, or between households and charities, both within or outside the country. The main motivation is to redistribute income either by government (e.g. pensions) or privately (e.g. child support). Current transfers received consist of all transfers that are not transfers of capital.

(a) Social security pensions / schemes - Social security pensions, insurance benefits and allowances generated from government sponsored social insurance schemes (compulsory/legal schemes) such as pensions (including military and overseas pensions), unemployment and sickness benefits.

(b) Pensions and other insurance benefits - Pensions and other insurance benefits from employer sponsored social insurance schemes and private funded schemes not covered by social security legislation (both funded and unfunded).

Pensions received from contributory or private funded schemes may represent a running down of the household's assets where the underlying capital is consumed. They are, however, included as income as they are considered as income by households, especially retired households, and are used for consumption.

(c) Social assistance benefits - Social assistance benefits from governments (universal or means-tested) which provide the same benefits as social security schemes, but which are not provided for under such schemes.

(d) Current transfers from non-profit institutions - Current transfers from non-profit institutions (e.g. charities, trade unions and religious bodies) in the form of regular gifts and financial support, such as scholarships, union strike pay, union sickness benefits and relief payments.

(e) Current transfers from other households - Current transfers from other households in the form of family support payments (such as alimony, child and parental support), regular receipts from inheritances and trust funds, regular gifts, financial support or transfers in kind of goods or services (e.g. housing or child care services). They include transfers from non-resident households (remittances) which can be of significant importance to the economic well-being of some households and are of particular policy interest for a number of developing countries.

5 Current transfers paid

Current transfers paid consist of direct taxes (net of refunds), compulsory fees and fines, current inter-household transfers paid, employees' social insurance contributions, and current transfers to non-profit institutions. 
The micro cash disposable income can be expressed as follows: $\mathrm{DI}=1+2+3+4-5$. The negative values recorded in the micro source (e.g. for self-employment income) are taken as they are, and not, for example, replaced with zeroes.

Prior to the classification of households at the micro level these micro variables used for the classification purpose are benchmarked to national accounts totals. The amounts declared by each household in micro sources were increased or decreased so that the weighted total across households matched with the adjusted national accounts total. In most cases, the benchmark process consisted of adjusting the amount reported by each household by the same proportion. The underlying assumption is that the gap between micro and macro totals reflected under-reporting by each household, i.e. that the distributional information from the micro source provides an adequate representation of the underlying distribution. In case of negative value, however, the benchmarking procedure is only applied to household declaring positive values ${ }^{26}$.

In some instance the above assumption is violated because of the presence of non-reporting by some households. For example, this may be true in the case of income to which a certain stigma is attached. In the United States for instance, what is known as "welfare" or "public assistance" has such a stigma, and the very low micro total compared to the macro total is in all likelihood accounted for by non-reporting by some certain type of households.

\section{Household type classification}

The two diagrams below describe i) how to classify each person in the households between adult and children living at home and ii) how to classify households in the eight household type groups.

26 Example of a 2 households sample (HH1;HH2). Each household represents 100 households $\left(W_{\text {HAL }}=W_{\text {HAL }}=100\right)$ and declare self-employment income $\left(S E_{\text {HHI }}=-1000 ; S E_{\text {HA2 }}=2000\right)$. The NA total is 200,000 whereas the micro weighted total is 100,000 $\left(5 E_{T \text { ctal }}=\Sigma_{\bar{i}} 5 E_{\text {HHi }}: W_{H H i}=100 *(-1000)+100 * 2000\right)$. In case of a simple calibration procedure the micro values should be calibrated as follows: $5 E_{\text {HAI }}=5 E_{\text {MAI }}$ and

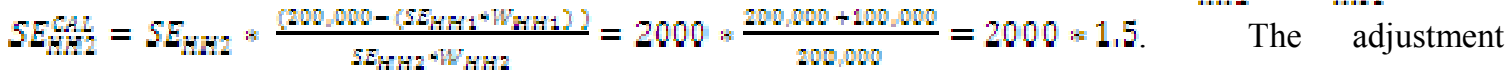
coefficient for the household declaring a positive value is 1.5 . After calibration the micro and macro totals are consistent. 
Diagram 1 - Classification of individual in two groups: adults and children living at home

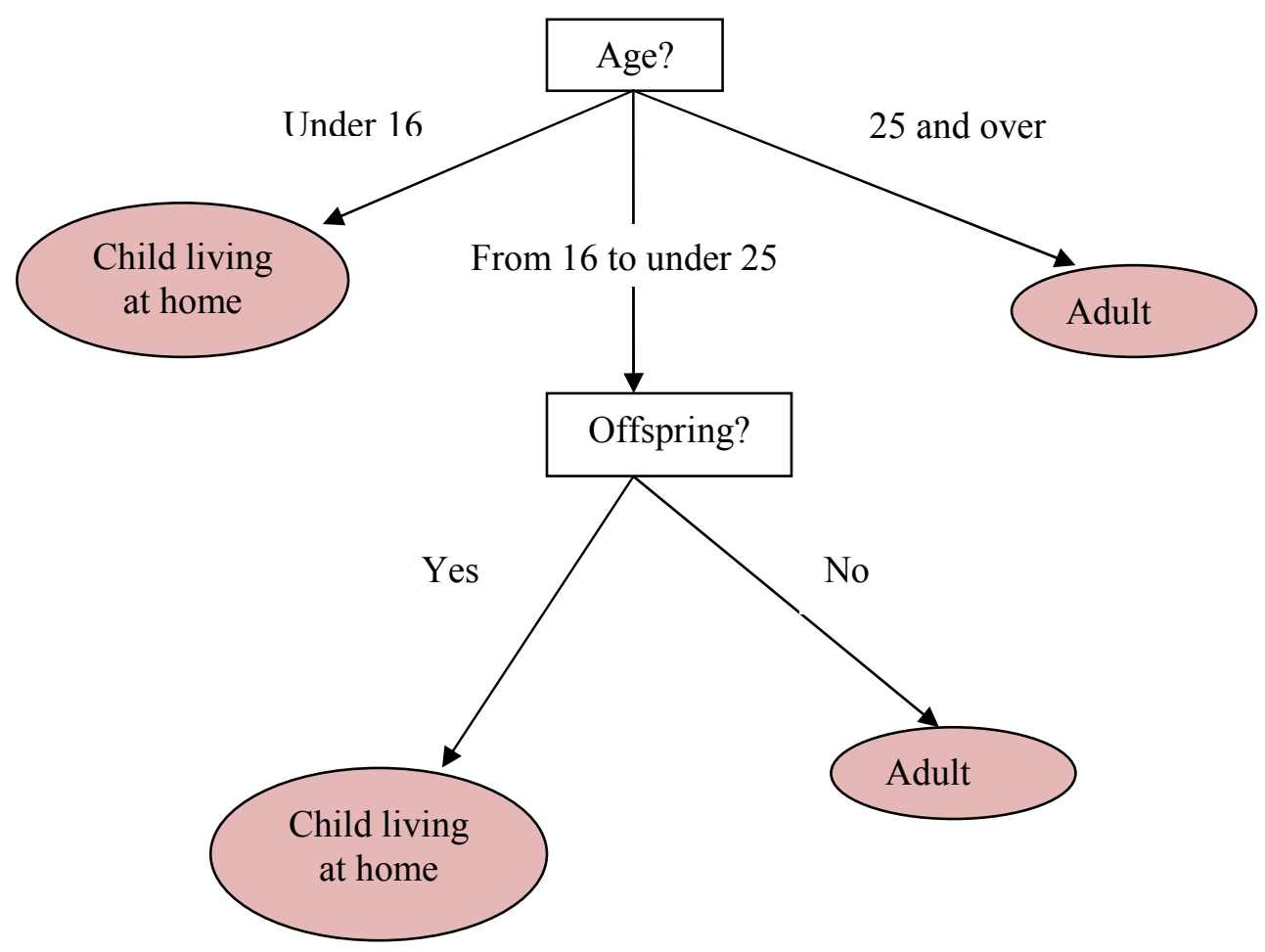


Diagram 2 - Classification of households in eight household type groups (from ' $a$ ' to ' $h$ ')

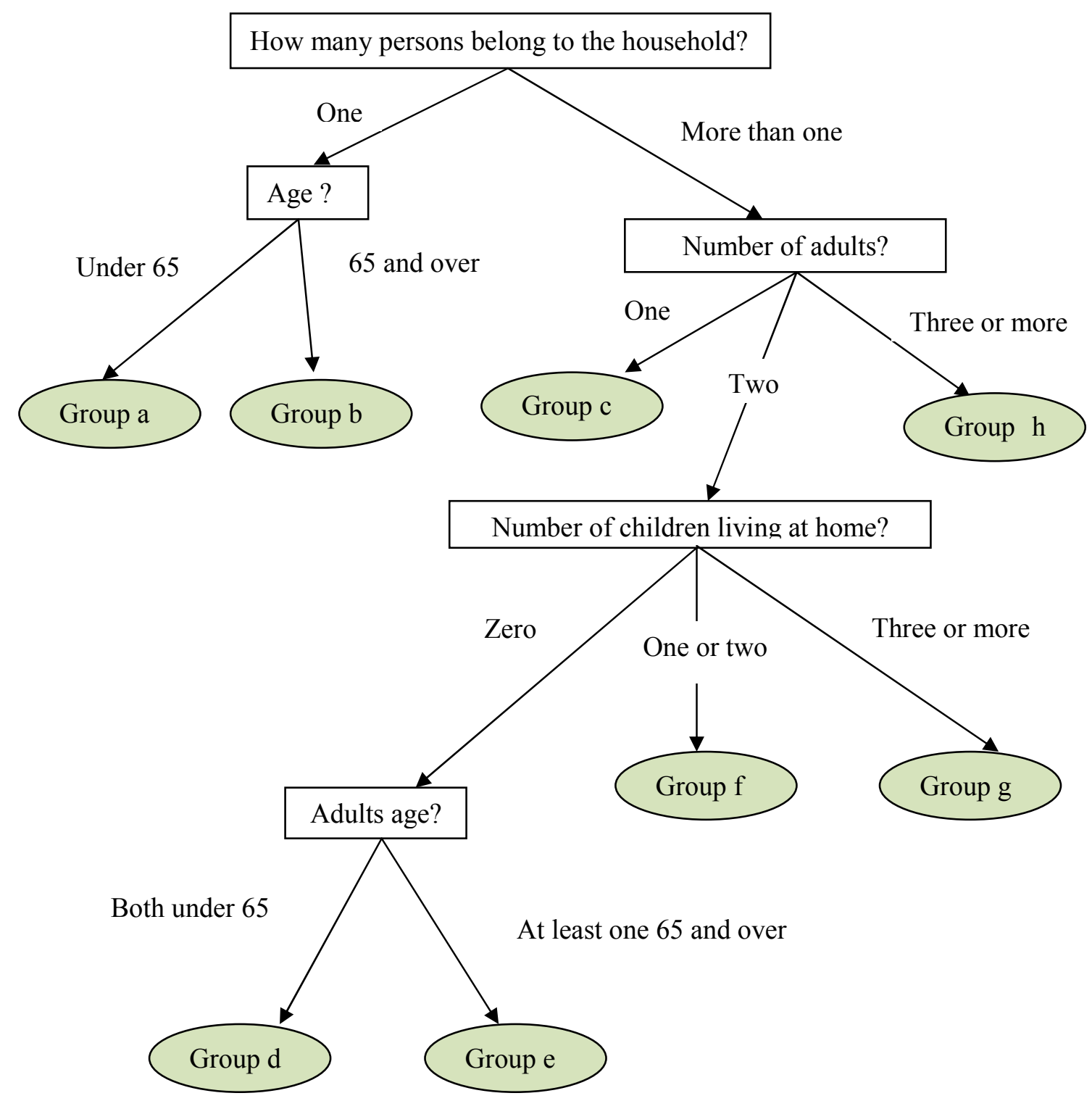




\section{Annex 3 - Expert Group template: list of components}

Below is the list of the income and consumption components for which national experts were asked to split the national accounts by household groups.

\begin{tabular}{|c|c|c|}
\hline \multicolumn{2}{|c|}{ Income components: } & \multirow{2}{*}{\begin{tabular}{|l|} 
SNA codes \\
$D 11 R$ \\
\end{tabular}} \\
\hline \multirow{19}{*}{ 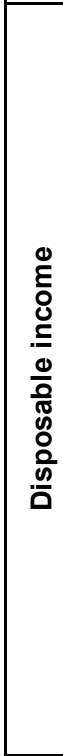 } & Wages and salaries & \\
\hline & Actual social contributions & $D 121 R$ \\
\hline & Imputed social contributions paid by firms & $D 122 R$ \\
\hline & Mixed income (excluding adjustment for underground production and own account production) & Part of B3 \\
\hline & Mixed income from underground production & Part of B3 \\
\hline & Mixed income from own-account production & Part of B3 \\
\hline & Operating surplus from leasing of dwelling & Part of $B 2$ \\
\hline & Operating surplus from owner occupied dwelling & Part of $B 2$ \\
\hline & $\begin{array}{l}\text { Property income received (before allocating Fisim to consumption and without income attributed to } \\
\text { insurance policy holders) }\end{array}$ & Part of D4R (D41R-Fisim on deposits+D42R+D45R) \\
\hline & Property income received attributed to insurance policy holders & Part of $D 4 R(D 44 R)$ \\
\hline & Property income paid (before allocating Fisim to consumption) & Part of D4P $(D 41 P+$ Fisim on loans $+D 45 P)$ \\
\hline & Fisim (fisim on loans + fisim on deposits) & Fisim on deposits and Fisim on loans (part of D41P and D41R) \\
\hline & Social benefits received & $D 62 R$ \\
\hline & Current taxes on income and wealth paid & $D 5 P$ \\
\hline & Actual social contributions paid by households & $D 611 P$ \\
\hline & Imputed social contributions paid by households & $D 612 P$ \\
\hline & Other current transfers (received minus paid, exluding non-life insurance claims and premiums) & $D 75 R-D 75 P$ \\
\hline & Transfers between resident households & No SNA specific code \\
\hline & Net non-life insurance premiums minus claims & $D 72 R-D 71 P$ \\
\hline \multirow{3}{*}{$\stackrel{y}{\mathfrak{E}}$} & Social transfers in kind received from the government - Health & Part of D63R \\
\hline & Social transfers in kind received from the government - Education & Part of $D 63 R$ \\
\hline & $\begin{array}{l}\text { Social transfers in kind received (other than education and health received from the government, } \\
\text { including all STiK provided by NPISHs) }\end{array}$ & Part of D63R \\
\hline
\end{tabular}




\begin{tabular}{|c|c|c|}
\hline \multicolumn{2}{|c|}{ Consumption components: } & \multirow{2}{*}{\begin{tabular}{|l|} 
SNA and COICOP codes \\
Part of 01
\end{tabular}} \\
\hline \multirow{26}{*}{ 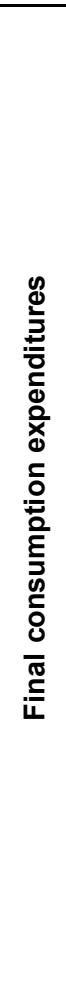 } & Food and non-alcoholic beverages (excluding own account production) & \\
\hline & Alcoholic beverages (excluding own account production) & Part of 02.1 \\
\hline & Own-account production & Part of 01 and of 02.1 \\
\hline & Tobacco & 02.2 \\
\hline & Narcotics & 02.3 \\
\hline & Clothing and footwear & 03 \\
\hline & Actual rentals for housing & 04.1 \\
\hline & Imputed rentals for housing & 04.2 \\
\hline & Maintenance and repair of the dwelling + water supply and miscellaneous services & $04.3+04.4$ \\
\hline & Electricity, gas and other fuels & 04.5 \\
\hline & Furnishings, household equipment and routine households maintenance & 05 \\
\hline & Medical products, appliances and equipment & 06.1 \\
\hline & Outpatient services & 06.2 \\
\hline & Hospital services & 06.3 \\
\hline & Purchases of vehicles & 07.1 \\
\hline & Operation of personal transport equipment & 07.2 \\
\hline & Transports services & 07.3 \\
\hline & Communications & 08 \\
\hline & Recreation and culture & 09 \\
\hline & Education & 10 \\
\hline & Restaurants and hotels & 11 \\
\hline & Miscellaneous goods and services (excluding Fisim, insurance expenditures and prostitution) & 12 (minus $12.6 .1,12.5$ and 12.2) \\
\hline & Fisim & 12.6 .1 \\
\hline & \begin{tabular}{|l} 
Insurances expenditures (life and non-life) \\
\end{tabular} & 12.5 \\
\hline & Prostitution & 12.2 \\
\hline & Resident households expenditures abroad & $P 33$ \\
\hline \multirow{3}{*}{ 旁 } & Social transfers in kind received from the government - Health & Part of D63R \\
\hline & Social transfers in kind received from the government - Education & Part of D63R \\
\hline & $\begin{array}{l}\text { Social transfers in kind received (other than education and health received from the government, } \\
\text { including all STiK provided by NPISHs) }\end{array}$ & Part of D63R \\
\hline
\end{tabular}


STD/DOC(2013)4

\section{Annex 4 - Breakdown - method and adjustment coefficients by component and by country}

For each component of the Expert Group template (Annex 3), the national account adjusted total was allocated to household groups using the most relevant distributional information. The type of distributional information used depends on what is available in micro source. Three methods were applied:

- Method A, applied when information on the distribution of the national accounts component $X$ is available in the micro source. For these components, the distributional information available in micro data source is used for the calculation;

- Method B, applied when no information on the distribution of the national accounts component $X$ is directly available in the micro source but where indirect information could be used. Two variants were applied for method B depending on whether the indirect information used was available in the micro source (proxy) or imputed by national experts (imputation, step 2). In the former case, the distributional information available for an income/expenditure component $\mathrm{Y}$ is used to distribute $\mathrm{X}$, assuming that $\mathrm{Y}$ and $\mathrm{X}$ are distributed in the same way. In the latter case, imputation of the distribution for the component $\mathrm{X}$ is performed at the micro level based on socio-demographic information available at the individual and at the household levels. In both cases the assumptions made to allocate totals can impact on the overall final distribution.

- Method C, applied when no information on the distribution was directly available, no imputation was performed and no proxy was available. For these income/expenditure components, the national accounts totals were distributed among all households in such a way that the inclusion or exclusion of these components did not impact on the aggregate disparity indicators. This implies that the income/consumption components considered was assumed to be distributed in the same way as the components for which method A and B were applied.

The distributional information is adjusted to match the adjusted national accounts total by component. In case of method A the adjustment coefficient, measured by dividing the adjusted national accounts total and the micro total, measures the gap existing between micro and macro totals for a similar component and scope.

This annex includes four tables showing i) the method used and ii) the adjustment coefficients obtained Method A was applied, successively for income and consumption components.

For practical and confidentiality reasons the information provided in this annex regarding the adjustment coefficients do not cover all the countries that participated in the experiment. As a consequence, the statistics shown in the working paper (tables 9 and 10) do not correspond to the statistics that would have been obtained if measured on the restricted set of countries listed in this annex. 
Table 1 - Method applied by income component and by country

\begin{tabular}{|c|c|c|c|c|c|c|c|c|}
\hline Label & $\begin{array}{l}\text { SNA codes, } \\
\text { for information }\end{array}$ & Australia & France & Germany & Israel & Italy & Japan & Korea \\
\hline Wages and salaries & $D 11 R$ & A & A & A & A & A & \multirow{23}{*}{ n.c. } & A \\
\hline Actual social contributions & $D 121 R$ & B & $A, B$ & n.a. & n.a. & A & & A \\
\hline Imputed social contributions paid by firms & $D 122 R$ & n.a. & $\mathrm{B}$ & n.a. & n.a. & B & & A \\
\hline $\begin{array}{l}\text { Mixed income (excluding adjustment for underground production and own account } \\
\text { production) }\end{array}$ & Part of B3 & $A, B$ & A & \multirow[t]{2}{*}{ A } & n.a. & B & & A \\
\hline Mixed income from underground production & Part of B3 & $\mathrm{B}$ & $\mathrm{B}$ & & n.a. & $\mathrm{B}$ & & n.a. \\
\hline \begin{tabular}{|l|} 
Mixed income from own-account production \\
\end{tabular} & Part of $B 3$ & $\mathrm{~B}$ & $\bar{A}$ & n.a. & n.a. & A & & n.a. \\
\hline Operating surplus from leasing of dwelling & Part of B2 & $A, B$ & A & A & n.a. & A & & $\mathrm{B}$ \\
\hline Operating surplus from owner occupied dwelling & Part of B2 & $A, B$ & A & A & n.a. & $A, B$ & & $\mathrm{C}$ \\
\hline $\begin{array}{l}\text { Property income received (before allocating Fisim to consumption and without } \\
\text { income attributed to insurance policy holders) }\end{array}$ & Part of D4R & $A, B$ & $A, B$ & A & n.a. & $A, B$ & & A \\
\hline Property income received attributed to insurance policy holders & Part of $D 4 R$ & $\mathrm{~B}$ & A & $\mathrm{B}$ & n.a. & $\mathrm{B}$ & & n.a. \\
\hline Property income paid (before allocating Fisim to consumption) & Part of D4P & $\mathrm{B}$ & $\mathrm{B}$ & A & n.a. & A & & $\mathrm{A}$ \\
\hline Fisim (fisim on loans + fisim on deposits) & Part of $D 4 P / R$ & B & n.a. & n.a. & n.a. & $\mathrm{B}$ & & C \\
\hline Social benefits received & $D 62 R$ & $A, B$ & A & A & A & A & & A \\
\hline Current taxes on income and wealth paid & $D 5 P$ & A & A & A & A & A & & A \\
\hline Actual social contributions paid by households & $D 611 P$ & $\mathrm{~B}$ & $A, B$ & $\bar{A}$ & n.a. & A & & A \\
\hline Imputed social contributions paid by households & $D 612 P$ & n.a. & $\mathrm{B}$ & n.a. & n.a. & B & & A \\
\hline $\begin{array}{l}\text { Other current transfers (received minus paid, exluding non-life insurance claims } \\
\text { and premiums) }\end{array}$ & $D 75 R-D 75 P$ & $A, B$ & $B, C$ & n.a. & n.a. & $A, B$ & & A \\
\hline Transfers between resident households & No SNA code & $\mathrm{B}$ & A & n.a. & n.a. & n.a. & & $\mathrm{A}$ \\
\hline Net non-life insurance premiums minus claims & $D 72 R-D 71 P$ & $\mathrm{C}$ & $\mathrm{B}$ & n.c. & n.a. & $\mathrm{C}$ & & $\mathrm{C}$ \\
\hline Social transfers in kind received from the government - Health & Part of D63R & A & $A, B$ & n.a. & $A, B$ & $\mathrm{~B}$ & & $\mathrm{~B}$ \\
\hline Social transfers in kind received from the government - Education & Part of D63R & A & $\mathrm{B}$ & n.a. & $A, B$ & $\mathrm{~B}$ & & $\mathrm{~B}$ \\
\hline $\begin{array}{l}\text { Social transfers in kind received (other than education and health received from } \\
\text { the government, including all STiK provided by NPISHs) }\end{array}$ & Part of D63R & B & $A, B$ & n.a. & n.a. & C & & B \\
\hline Change in net equity of households in pension funds & $D 8$ & $\mathrm{~B}$ & n.a. & n.a. & n.a. & $\mathrm{B}$ & & $\mathrm{B}$ \\
\hline
\end{tabular}

n.a.: not applicable (not part of the household national accounts; component not studied as part of the Expert Group work); n.c.: no information provided on the method applied 
Table 1 - Method applied by income component and by country (followed)

\begin{tabular}{|c|c|c|c|c|c|c|c|c|c|}
\hline Label & $\begin{array}{l}\text { SNA codes, } \\
\text { for information }\end{array}$ & Mexico & Netherlands & Portugal & $\begin{array}{c}\text { New } \\
\text { Zealand }\end{array}$ & Slovenia & Sweden & Switzerland & $\begin{array}{l}\text { United } \\
\text { States }\end{array}$ \\
\hline Wages and salaries & $D 11 R$ & A & A & n.a. & A & A & $\mathrm{A}, \mathrm{B}$ & A & A \\
\hline Actual social contributions & $D 121 R$ & $\mathrm{~B}$ & A & n.a. & $\mathrm{B}$ & \multirow{2}{*}{ B } & $\mathrm{B}$ & A & $\mathrm{A}, \mathrm{B}$ \\
\hline Imputed social contributions paid by firms & $D 122 R$ & $\mathrm{~B}$ & $\mathrm{~B}$ & n.a. & n.a. & & $B$ & $\mathrm{~B}$ & n.a. \\
\hline $\begin{array}{l}\text { Mixed income (excluding adjustment for underground production and own account } \\
\text { production) }\end{array}$ & Part of B3 & \multirow{4}{*}{ A } & A & \multirow{3}{*}{$A, B$} & n.a. & A & A & \multirow{5}{*}{ A } & A \\
\hline Mixed income from underground production & Part of B3 & & $\mathrm{B}$ & & n.a. & & $B$ & & $B$ \\
\hline Mixed income from own-account production & Part of B3 & & $\mathrm{B}$ & & n.a. & A & $\mathrm{B}$ & & n.a. \\
\hline Operating surplus from leasing of dwelling & Part of $B 2$ & & A & n.a. & n.a. & $\mathrm{B}$ & n.a. & & A \\
\hline Operating surplus from owner occupied dwelling & Part of $B 2$ & A & A & n.a. & $B$ & $B$ & $B$ & & $A, B$ \\
\hline $\begin{array}{l}\text { Property income received (before allocating Fisim to consumption and without } \\
\text { income attributed to insurance policy holders) }\end{array}$ & Part of $D 4 R$ & A & A & n.a. & $A, B$ & $A, B$ & $A, C$ & A & $A, B$ \\
\hline Property income received attributed to insurance policy holders & Part of D4R & $\mathrm{B}$ & $\mathrm{B}$ & n.a. & $\mathrm{B}$ & $B$ & $A, B$ & n.a. & $B$ \\
\hline Property income paid (before allocating Fisim to consumption) & Part of $D 4 P$ & A & A & n.a. & A & \multirow{2}{*}{$A, B$} & $\mathrm{~A}, \mathrm{~B}$ & A & $\mathrm{A}, \mathrm{B}$ \\
\hline Fisim (fisim on loans + fisim on deposits) & Part of $D 4 P / R$ & n.a. & $\mathrm{B}$ & n.a. & n.a. & & $\mathrm{B}$ & $\mathrm{B}$ & $\mathrm{B}$ \\
\hline Social benefits received & $D 62 R$ & A & A & n.a. & $\mathrm{A}, \mathrm{B}$ & A & A & A & $A, B$ \\
\hline Current taxes on income and wealth paid & $D 5 P$ & $\mathrm{~B}$ & A & n.a. & $\mathrm{A}, \mathrm{B}$ & A & A & A & $\mathrm{A}, \mathrm{B}$ \\
\hline Actual social contributions paid by households & $D 611 P$ & $\mathrm{~B}$ & A & n.a. & $A, B$ & \multirow{2}{*}{ B } & $A, B$ & A & $A, B$ \\
\hline Imputed social contributions paid by households & $D 612 P$ & $\mathrm{~B}$ & $\mathrm{~B}$ & n.a. & n.a. & & $A, B$ & $\mathrm{~B}$ & $\mathrm{~B}$ \\
\hline $\begin{array}{l}\text { Other current transfers (received minus paid, exluding non-life insurance claims } \\
\text { and premiums) }\end{array}$ & $D 75 R-D 75 P$ & A & A & n.a. & $A, B$ & B & B & A & B \\
\hline Transfers between resident households & No SNA code & n.a. & $\mathrm{B}$ & n.a. & n.a. & n.a. & $\mathrm{B}$ & n.a. & A \\
\hline Net non-life insurance premiums minus claims & $D 72 R-D 71 P$ & A & n.a. & n.a. & A & $\mathrm{B}$ & $\mathrm{B}$ & n.a. & n.a. \\
\hline Social transfers in kind received from the government - Health & Part of D63R & $\mathrm{B}$ & $\mathrm{B}$ & n.a. & $\mathrm{B}$ & $B$ & $A$ or $B$ & n.a. & $\mathrm{A}, \mathrm{B}$ \\
\hline Social transfers in kind received from the government - Education & Part of D63R & $\mathrm{B}$ & $\mathrm{B}$ & n.a. & $\mathrm{B}$ & $B$ & A & n.a. & $B$ \\
\hline $\begin{array}{l}\text { Social transfers in kind received (other than education and health received from } \\
\text { the government, including all STIK provided by NPISHs) }\end{array}$ & Part of D63R & C & $B, C$ & n.a. & B & B & $A, B$ & n.a. & B \\
\hline Change in net equity of households in pension funds & $D 8$ & $\mathrm{~B}$ & $\mathrm{~B}$ & n.a. & $\mathrm{A}, \mathrm{B}$ & $\mathrm{B}$ & $\mathrm{B}$ & $\mathrm{B}$ & $\mathrm{A}, \mathrm{B}$ \\
\hline
\end{tabular}

n.a.: not applicable (not part of the household national accounts; component not studied as part of the Expert Group work); n.c.: no information provided on the method applied 
Table 2 - Method applied by consumption component and by country

\begin{tabular}{|c|c|c|c|c|c|c|c|c|}
\hline Label & $\begin{array}{l}\text { SNA codes, } \\
\text { information }\end{array}$ & Australia & France & Israel & Italy & Korea & Mexico & Netherlands \\
\hline Food and non-alcoholic beverages (excluding own account production) & Part of 01 & A & $\mathrm{B}$ & A & A & A & A & A \\
\hline Alcoholic beverages (excluding own account production) & Part of 02.1 & A & A & A & A & A & A & A \\
\hline Own-account production & Part of 01 and of 02.1 & $\mathrm{~B}$ & n.a. & A & n.c. & $\mathrm{C}$ & A & B \\
\hline Tobacco & 02.2 & A & A & A & A & A & A & A \\
\hline Narcotics & 02.3 & n.a. & n.a. & n.a. & n.a. & n.a. & n.a. & n.a. \\
\hline Clothing and footwear & 03 & $\mathrm{~A}$ & A & A & A & A & A & A \\
\hline Actual rentals for housing & 04.1 & A & A & A & A & A & A & A \\
\hline Imputed rentals for housing & 04.2 & A & $\mathrm{B}$ & A & A & $\mathrm{C}$ & A & A \\
\hline Maintenance and repair of the dwelling + water supply and miscellaneous services & $04.3+04.4$ & A & A & A & A & A & A & A \\
\hline Electricity, gas and other fuels & 04.5 & A & A & A & A & A & A & A \\
\hline Furnishings, household equipment and routine households maintenance & 05 & A & A & A & A & A & A & A \\
\hline Medical products, appliances and equipment & 06.1 & A & A & A & A & A & A & A \\
\hline Outpatient services & 06.2 & A & A & A & A & A & A & A \\
\hline Hospital services & 06.3 & A & A & A & A & A & A & A \\
\hline Purchases of vehicles & 07.1 & A & A & A & A & A & A & A \\
\hline Operation of personal transport equipment & 07.2 & A & A & A & A & A & A & A \\
\hline Transports services & 07.3 & A & B & A & A & A & A & A \\
\hline Communications & 08 & A & A & A & A & A & A & A \\
\hline Recreation and culture & 09 & A & $\mathrm{B}$ & A & A & A & A & A \\
\hline Education & 10 & A & $\mathrm{A}$ & A & A & A & A & A \\
\hline Restaurants and hotels & 11 & A & $\mathrm{B}$ & A & A & A & A & A \\
\hline $\begin{array}{l}\begin{array}{l}\text { Miscellaneous goods and services (excluding Fisim, insurance expenditures and } \\
\text { prostitution) }\end{array} \\
\end{array}$ & 12 (minus 12.6.1, 12.5 and 12.2) & A & A & A & A & A & A & A \\
\hline Fisim & 12.6 .1 & $\mathrm{~B}$ & n.a. & n.a. & n.a. & $\mathrm{C}$ & n.a. & $\mathrm{B}$ \\
\hline Insurances expenditures (life and non-life) & 12.5 & $\mathrm{~B}$ & A & A & $\mathrm{A}$ & A & $\mathrm{A}$ & $\mathrm{A}$ \\
\hline Prostitution & 12.2 & n.a. & n.a. & n.a. & n.a. & n.a. & n.a. & ก.a. \\
\hline Resident households expenditures abroad & $\mid \frac{1.2}{P 33}$ & B.a. & n.a. & n.a. & B & C.a. & C.a. & C.a. \\
\hline Social transfers in kind received from the government - Health & Part of D63R & A & $A, B$ & $A, B$ & B & B & B & B \\
\hline Social transfers in kind received from the government - Education & Part of $D 63 R$ & A & $\mathrm{B}$ & $A, B$ & $\mathrm{~B}$ & $\mathrm{~B}$ & $\mathrm{~B}$ & B \\
\hline $\begin{array}{l}\text { Social transfers in kind received (other than education and health received from the } \\
\text { government, including all STiK provided by NPISHs) }\end{array}$ & Part of $D 63 R$ & B & $A, B$ & n.a. & C & B & C & $B, C$ \\
\hline
\end{tabular}

n.a.: not applicable (not part of the household national accounts; component not studied as part of the Expert Group work); n.c.: no information provided on the method applied 
Table 2 - Method applied by consumption component and by country (followed)

\begin{tabular}{|c|c|c|c|c|c|c|c|}
\hline Label & $\begin{array}{l}\text { SNA codes, } \quad \text { for } \\
\text { information }\end{array}$ & $\begin{array}{c}\text { New } \\
\text { Zealand }\end{array}$ & Portugal* ${ }^{*}$ & Slovenia & Sweden & Switzerland & $\begin{array}{l}\text { United } \\
\text { States }\end{array}$ \\
\hline Food and non-alcoholic beverages (excluding own account production) & Part of 01 & A & A & A & A & A & A \\
\hline Alcoholic beverages (excluding own account production) & Part of 02.1 & A & A & A & A & A & A \\
\hline Own-account production & Part of 01 and of 02.1 & & A & A & A & n.a. & $\mathrm{B}$ \\
\hline Tobacco & 02.2 & A & A & A & A & A & A \\
\hline Narcotics & 02.3 & n.a. & n.a. & $\mathrm{B}$ & $\mathrm{C}$ & n.a. & n.a. \\
\hline Clothing and footwear & 03 & A & A & A & A & A & A \\
\hline Actual rentals for housing & 04.1 & A & A & A & A & A & A \\
\hline Imputed rentals for housing & 04.2 & $\mathrm{~B}$ & A & A & $\mathrm{B}$ & A & A \\
\hline Maintenance and repair of the dwelling + water supply and miscellaneous services & $04.3+04.4$ & A & A & A & A & A & A \\
\hline Electricity, gas and other fuels & 04.5 & A & A & A & A & A & A \\
\hline Furnishings, household equipment and routine households maintenance & 05 & A & A & A & A & A & A \\
\hline Medical products, appliances and equipment & 06.1 & A & A & A & A & A & $\mathrm{A}, \mathrm{B}$ \\
\hline Outpatient services & 06.2 & A & A & $\mathrm{B}$ & A & A & $A, B$ \\
\hline Hospital services & 06.3 & A & A & $\mathrm{B}$ & $\mathrm{B}$ & A & $A, B$ \\
\hline Purchases of vehicles & 07.1 & $A, B$ & A & $\mathrm{A}$ & $\mathrm{A}$ & A & A \\
\hline Operation of personal transport equipment & 07.2 & $A, B$ & A & A & A & A & A \\
\hline Transports services & 07.3 & $A, B$ & A & A & $\mathrm{A}$ & $\mathrm{A}$ & $\mathrm{A}$ \\
\hline Communications & 08 & $\mathrm{~A}$ & A & A & A & A & A \\
\hline Recreation and culture & 09 & $A, B$ & A & A & A & A & A \\
\hline Education & 10 & A & A & A & A & A & A \\
\hline Restaurants and hotels & 11 & A & A & A & A & A & \\
\hline $\begin{array}{l}\text { Miscellaneous goods and services (excluding Fisim, insurance expenditures and } \\
\text { prostitution) }\end{array}$ & 12 (minus 12.6.1, 12.5 and 12.2) & A & A & A & A & A & $A, B$ \\
\hline Fisim & 12.6 .1 & n.a. & n.a. & B & B & B & $\mathrm{B}$ \\
\hline Insurances expenditures (life and non-life) & 12.5 & n.a. & n.a. & $\mathrm{B}$ & $A, B$ & A & $\mathrm{B}$ \\
\hline Prostitution & 12.2 & n.a. & n.a. & B & C & n.a. & n.a. \\
\hline Resident households expenditures abroad & $P 33$ & A & n.a. & A & $\mathrm{B}$ & A & n.a. \\
\hline Social transfers in kind received from the government - Health & Part of D63R & $\mathrm{B}$ & n.a. & $\mathrm{B}$ & $\mathrm{A}$ or $\mathrm{B}$ & n.a. & $\mathrm{A}, \mathrm{B}$ \\
\hline Social transfers in kind received from the government - Education & Part of D63R & $\mathrm{B}$ & n.a. & $\mathrm{B}$ & A & n.a. & $\mathrm{B}$ \\
\hline $\begin{array}{l}\text { Social transfers in kind received (other than education and health received from the } \\
\text { government, including all STiK provided by NPISHs) }\end{array}$ & Part of D63R & B & n.a. & B & $A, B$ & n.a. & B \\
\hline
\end{tabular}

ele (not pat of the houschold national

n.a.: not applicable (not part of the household national accounts; component not studied as part of the Expert Group work); n.c. no information provided on the method applied

*: For Portugal "Food and non-alcoholic beverages" and "Alcoholic beverages" are available and broken down but without excluding own account production. 
Table 3 - Adjustment coefficient when Method A applied by income component and by country

\begin{tabular}{|c|c|c|c|c|c|c|c|c|c|c|c|c|}
\hline & Australia & Israel & Italy & Korea & $\begin{array}{c}\text { Mexico } \\
(2010)\end{array}$ & Netherlands & $\begin{array}{c}\text { New } \\
\text { Zealand }\end{array}$ & Portugal & Slovenia & Sweden & Switzerland & $\begin{array}{l}\text { United } \\
\text { States }\end{array}$ \\
\hline Wages and salaries & 1.0 & 1.2 & 1.4 & 1.2 & 1.5 & 0.9 & 1.1 & & 1.2 & & 1.0 & 1.0 \\
\hline Actual social contributions & & & 1.0 & 1.2 & 1.0 & 4.7 & & & & & 1.3 & \\
\hline Imputed social contributions paid by firms & & & & 5.2 & 1.0 & & & & & & 0.1 & \\
\hline $\begin{array}{l}\text { Mixed income (excluding adjustment for underground production and own } \\
\text { account production) }\end{array}$ & & & & 0.9 & \multirow{4}{*}{7.5} & 1.1 & & \multirow{3}{*}{1.7} & 2.5 & 1.7 & 0.9 & 2.0 \\
\hline Mixed income from underground production & & & & & & & & & & & & \\
\hline Mixed income from own-account production & & & 0.7 & & & & & & 2.3 & & & \\
\hline Operating surplus from leasing of dwelling & 1.9 & & 1.4 & & & 0.6 & & & 0.7 & & & 2.3 \\
\hline Operating surplus from owner occupied dwelling & 0.5 & & & & 1.3 & 2.4 & & & 1.0 & & & \\
\hline $\begin{array}{l}\text { Property income received (before allocating Fisim to consumption and } \\
\text { without income attributed to insurance policy holders) }\end{array}$ & & & & 9.8 & 16.5 & 2.2 & & & & & 4.0 & \\
\hline Property income received attributed to insurance policy holders & & & & & & & & & & 4.2 & & \\
\hline Property income paid (before allocating Fisim to consumption) & & & 2.3 & 5.0 & 38.6 & 1.1 & & & & & 1.6 & \\
\hline \multicolumn{13}{|l|}{ Fisim (fisim on loans + fisim on deposits) } \\
\hline Social benefits received & & 1.1 & 1.3 & 2.3 & 1.6 & 1.1 & & & 1.1 & 1.1 & 1.6 & \\
\hline Current taxes on income and wealth paid & 1.2 & 1.1 & 1.1 & 2.9 & & 1.2 & & & 1.2 & 1.0 & 1.4 & \\
\hline Actual social contributions paid by households & & & 1.0 & 2.0 & & 1.0 & & & 2.1 & & 1.3 & \\
\hline Imputed social contributions paid by households & & & & 5.2 & 1.0 & & & & & & 0.1 & \\
\hline $\begin{array}{l}\text { Other current transfers (received minus paid, exluding non-life insurance } \\
\text { claims and premiums) }\end{array}$ & & & & & & 2.7 & & & & & & \\
\hline \multicolumn{13}{|l|}{ Transfers between resident households } \\
\hline \multicolumn{13}{|l|}{ Net non-life insurance premiums minus claims } \\
\hline Social transfers in kind received from the government - Health & 0.9 & & & & 1.0 & & & & & 1.5 & & \\
\hline Social transfers in kind received from the government - Education & 0.8 & & & & 0.9 & & & & & 1.0 & & \\
\hline $\begin{array}{l}\text { Social transfers in kind received (other than education and health } \\
\text { received from the government, including all STIK provided by NPISH) }\end{array}$ & 1.0 & & & 7.5 & & & & & & 2.2 & & \\
\hline Change in net equity of households in pension funds & & & & & 1.0 & & & & & & 2.7 & \\
\hline
\end{tabular}


Table 4 - Adjustment coefficient when Method A applied by consumption component and by country

\begin{tabular}{|c|c|c|c|c|c|c|c|c|c|c|c|c|}
\hline & Australia & Israel & Italy & Korea & $\begin{array}{l}\text { Mexico } \\
(2010)\end{array}$ & Netherlands & $\begin{array}{c}\text { New } \\
\text { Zealand }\end{array}$ & Portugal ${ }^{*}$ & Slovenia & Sweden & Switzerland & $\begin{array}{l}\text { United } \\
\text { States }\end{array}$ \\
\hline $\begin{array}{l}\text { Food and non-alcoholic beverages (excluding own account } \\
\text { production) }\end{array}$ & 1.1 & 1.3 & 1.0 & 1.2 & 4.1 & 1.1 & 1.5 & 1.7 & 1.0 & 1.1 & 1.0 & 1.5 \\
\hline Alcoholic beverages (excluding own account production) & 1.5 & 3.1 & 1.3 & 3.6 & 25.3 & 1.2 & 3.3 & 2.7 & 1.9 & 1.9 & 1.9 & 2.1 \\
\hline Own-account production & & & & & & & & 0.8 & 1.6 & & & \\
\hline Tobacco & 2.1 & 2.6 & 2.6 & 2.4 & 10.9 & 3.0 & 3.0 & 2.2 & 3.0 & 2.2 & 3.1 & 2.1 \\
\hline \multicolumn{13}{|l|}{ Narcotics } \\
\hline Clothing and footwear & 1.3 & 1.1 & 1.4 & 1.2 & 1.5 & 1.1 & 1.6 & 2.2 & 1.0 & 1.0 & 1.0 & 1.7 \\
\hline Actual rentals for housing & 0.9 & 0.9 & 1.0 & 2.7 & 4.4 & 0.8 & 1.0 & 1.4 & 0.6 & 0.9 & \multirow{2}{*}{0.9} & 1.1 \\
\hline Imputed rentals for housing & 1.0 & 1.1 & 0.8 & & 1.6 & 1.0 & & 0.6 & 0.8 & & & 0.9 \\
\hline $\begin{array}{l}\text { Maintenance and repair of the dwelling + water supply and } \\
\text { miscellaneous services }\end{array}$ & 1.2 & 1.0 & 1.7 & 0.7 & 3.6 & 0.8 & 2.1 & 1.7 & 0.7 & 0.2 & & 1.4 \\
\hline Electricity, gas and other fuels & 1.1 & 1.1 & 0.9 & 1.0 & 2.5 & 1.1 & 1.0 & 1.2 & 1.0 & 1.8 & 1.3 & 1.0 \\
\hline $\begin{array}{l}\text { Furnishings, household equipment and routine households } \\
\text { maintenance }\end{array}$ & 1.1 & 1.7 & 2.2 & 1.3 & 3.0 & 1.2 & 1.6 & 2.1 & 1.1 & 0.9 & 1.2 & 2.3 \\
\hline Medical products, appliances and equipment & 1.3 & 1.0 & 0.8 & 0.8 & 7.6 & 1.3 & & 1.1 & 1.8 & 1.2 & 1.8 & \\
\hline Outpatient services & 1.4 & 0.7 & 0.8 & 1.6 & 7.7 & 2.7 & & 1.7 & & 2.3 & 2.6 & \\
\hline Hospital services & 12.1 & 4.1 & 11.3 & 1.8 & 2.7 & 16.1 & & 1.3 & & & 37.4 & \\
\hline Purchases of vehicles & 1.0 & 1.3 & 2.0 & 1.5 & 8.0 & 0.9 & & 3.1 & 1.0 & 0.7 & 1.2 & 1.8 \\
\hline Operation of personal transport equipment & 0.7 & 0.8 & 1.3 & 1.2 & 5.1 & 1.2 & & 1.6 & 1.3 & 1.1 & 0.7 & \\
\hline Transports services & 1.5 & 1.1 & 2.0 & 2.0 & 4.5 & 1.6 & & 2.0 & 2.3 & 1.9 & 1.0 & \\
\hline Communications & 1.0 & 1.3 & 1.5 & 1.1 & 3.4 & 1.6 & 1.2 & 1.7 & 0.9 & 1.4 & 1.1 & \\
\hline Recreation and culture & 1.3 & 1.7 & 1.9 & 2.3 & 3.4 & 1.1 & & 2.0 & 1.0 & 0.8 & 1.0 & 2.2 \\
\hline Education & 1.1 & 0.8 & 1.4 & 0.9 & 1.4 & 0.6 & 1.2 & 1.0 & 2.0 & & 1.0 & \\
\hline Restaurants and hotels & 1.1 & 2.9 & 2.3 & 0.9 & 1.9 & 1.0 & 1.8 & 1.2 & 2.3 & 1.4 & 0.8 & \\
\hline $\begin{array}{l}\text { Miscellaneous goods and services (excluding Fisim, insurance } \\
\text { expenditures and prostitution) }\end{array}$ & 1.4 & 2.0 & 1.9 & 1.4 & 2.4 & 1.9 & 1.2 & 2.7 & 1.8 & 2.7 & & \\
\hline \multicolumn{13}{|l|}{ Fisim } \\
\hline Insurances expenditures (life and non-life) & & 0.6 & 2.2 & 2.5 & & 0.5 & & & & & 0.7 & \\
\hline \multicolumn{13}{|l|}{ Prostitution } \\
\hline Resident households expenditures abroad & & & 2.2 & & & & 2.5 & & 10.0 & & & \\
\hline Social transfers in kind received from the government - Health & 0.9 & & & & 1.0 & & & & & 1.5 & & \\
\hline $\begin{array}{l}\text { Social transfers in kind received from the government - } \\
\text { Education }\end{array}$ & 0.8 & & & & 0.9 & & & & & 1.0 & & \\
\hline $\begin{array}{l}\text { Social transfers in kind received (other than education and } \\
\text { health received from the government, including all STIK provided } \\
\text { by NPISHs) }\end{array}$ & 1.0 & & & 7.5 & & & & & & 2.2 & & \\
\hline
\end{tabular}

by NPISHs)

*: For Portugal "Food and non-alcoholic beverages" and "Alcoholic beverages" are available and broken down but without excluding own account production. 


\section{Annex 5 - Impact of the household structure on the disparity index}

The disparity index is the coefficient of variation showing how much variation exists from the average across households. For a given household grouping (i.e., Equivalized Disposable Income quintile, Main Source of Income and Household Type), the coefficient of variation (CV) is the ratio of the standard deviation to the mean calculated as follows:

$$
\begin{aligned}
& C V_{z}=\frac{\sqrt{\frac{1}{N} \times \sum_{i \in z}\left[n_{i} \times\left(\bar{X}_{i}^{N A_{\text {adj }}}-\bar{X}^{N A_{-} a d j}\right)^{2}\right]}}{\bar{X}^{N A_{-} a d j}} * 100 \\
& \bar{X}^{N A_{-} a d j}=\frac{1}{N} \sum_{i \in z} n_{i} \times \bar{X}_{i}^{N A_{\text {adj }}}
\end{aligned}
$$

In the above formulas:

$\mathrm{X}$ : income/consumption component

$z=\{$ MSI,EDI, HT $\}$ identifies the household grouping variable

$i=[1, \ldots, l]$ identifies each household group

$n_{i}$ : is the total number of households in group $i$

$\mathrm{N}$ : is the total number of household in the population

$\bar{K}_{i}^{\text {NA_adj }}:$ is the per household or per consumption unit adjusted national accounts for group $i$

$\bar{X}^{\text {NA_adj }}$ : is the per household or per consumption unit adjusted national accounts

The disparity index measured following the above calculation depends on the household structure in each country. Consequently, divergences in coefficient of variations between two countries may be explained by two factors: cross country differences in the extent to which one given household group depart from the average; and cross country differences in the share of the household groups in the total household population. A second measure assumes that each household group has the same weight across the across countries. The index is then computed as follows:

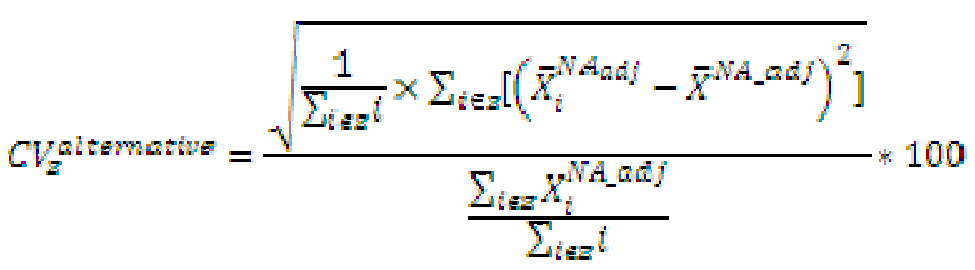




\section{Impact on disparity index measured on income}

When the impact of the household structure is controlled for, income disparity is generally increased, in particular for the Main Source of Income classification, because the household groups that diverge most significantly from the average (e.g., the Property Income and Income from self-employment groups) have a relatively low share in the total household population. Controlling for the effect of household structure may also change the cross country comparison due to differences in structure across countries. Heterogeneity between the extreme countries is thus reduced: e.g., income disparity is 4.5 times higher in Mexico than in Slovenia when considering Main Source of Income and the household structure is controlled for, as compared to 6.5 when the true household population structure is used (Table 1).

Table 1: The impact of household structure on the disparity index measured on income by Main Source of Income and Household Type

Disparity index in each country to the lowest value of the disparity index, on adjusted Disposable income per consumption unit

\begin{tabular}{|l|c|c|c|c|}
\cline { 2 - 4 } \multicolumn{1}{c|}{} & \multicolumn{2}{c|}{ Main Source of Income } & \multicolumn{2}{c|}{ House hold Type } \\
\cline { 2 - 5 } \multicolumn{1}{c|}{} & Disparity index & $\begin{array}{c}\text { Household } \\
\text { structure controlled }\end{array}$ & Disparity index & $\begin{array}{c}\text { Household } \\
\text { structure controlled }\end{array}$ \\
\hline France 2003 & 1.1 & 1.2 & 1.6 & 1.2 \\
\hline Italy 2008 & 1.2 & 1.2 & 1.0 & 1.0 \\
\hline Korea 2009 & 0.9 & 1.1 & 2.0 & 2.0 \\
\hline Mexico 2008 & 6.2 & 4.3 & 3.4 & 3.1 \\
\hline Mexico 2010 & 6.5 & 4.5 & 2.8 & 2.6 \\
\hline Netherlands 2008 & 1.6 & 1.8 & 2.1 & 1.5 \\
\hline New Zealand 2006-07 & 1.3 & 1.4 & 1.9 & 1.7 \\
\hline Slovenia 2008 & 1.0 & 1.0 & 1.7 & 1.5 \\
\hline United States 2010 & 1.6 & 1.9 & 1.8 & 1.5 \\
\hline
\end{tabular}

Note: For the Main Source of Income grouping Slovenia is showing the lowest disparity index no matter whether the household population structure is controlled. Compared to Slovenia, income disparity is 6.5 times higher in Mexico; income disparity is 4.5 times higher in Mexico than in Slovenia when the household structure is controlled for.

2.

\section{Impact on disparity index measured on consumption}

In France, Mexico and in the United States, controlling for the household structure has a major impact on consumption disparity when households are classified according to Main Source of Income. This is because the household group Property Income, which are very far from the average in these countries, have a low share in the total household population. In Slovenia, controlling for the household structure shows a significant impact when households are classified by Household Type. This is because in Slovenia single adults who are living alone, whatever their age, show consumption expenditures quite distinct from the average, while having a relatively low share in total household population. 
Table 2: The impact of household structure on the disparity index measured on consumption by Main Source of Income and Household Type

Actual final consumption per consumption unit

\begin{tabular}{|l|c|c|c|c|}
\cline { 2 - 5 } \multicolumn{1}{c|}{} & \multicolumn{2}{c|}{ Main Source of Income } & \multicolumn{2}{c|}{ Household Type } \\
\cline { 2 - 5 } \multicolumn{1}{c|}{} & Disparity index & $\begin{array}{c}\text { Household } \\
\text { structure } \\
\text { controlled }\end{array}$ & Disparity index & $\begin{array}{c}\text { Household } \\
\text { structure } \\
\text { controlled }\end{array}$ \\
\hline France 2003 & 2.2 & 3.4 & 1.2 & 1.3 \\
\hline Italy 2008 & 1.0 & 1.0 & 2.8 & 2.8 \\
\hline Korea 2009 & 2.7 & 4.5 & 2.7 & 2.5 \\
\hline Mexico 2008 & 2.5 & 4.5 & 3.0 & 3.2 \\
\hline Mexico 2010 & 1.1 & 1.4 & 1.0 & 3.3 \\
\hline Netherlands 2008 & 1.6 & 1.7 & 1.4 & 1.0 \\
\hline New Zealand 2006-07 & 1.4 & 1.4 & 3.8 & 3.1 \\
\hline Slovenia 2008 & 2.2 & 4.1 & 1.1 & 1.2 \\
\hline United States 2010 & & & & \\
\hline
\end{tabular}

Note: For the Main Source of Income quintile grouping Korea is showing the lowest disparity index no matter whether the household population structure is controlled. Compared to Korea, consumption disparity is 2.5 times higher in Mexico; consumption disparity is 4.5 times higher in Mexico than in Korea when the household structure is controlled for. 
STD/DOC(2013)4

\section{Annex 6 - Impact of benchmarking micro income variables to national accounts totals}

To create the two income variables used to group households (i.e., EDI, MSI), national experts made use of the income variables available in micro sources for wages and salaries, income from self-employment, property income received and paid, and current transfers received and paid. Prior to the creation of the income variables used to create groups of households, the micro income variables were benchmarked to national accounts totals ${ }^{27}$. The amounts declared by each household in micro sources were increased or decreased so that the weighted total across households matched with the adjusted national accounts total. In most cases, the benchmark process consisted of adjusting the amount reported by each household by the same proportion. The underlying assumption is that the gap between micro and macro totals reflected under-reporting by each household, i.e. that the distributional information from the micro source provides an adequate representation of the underlying distribution.

\section{Impact on the household structure}

The benchmarking of micro income variables to national accounts applied prior to the classification of households may impact on how households are classified according to Main Source of Income and Equivalized Disposable Income quintile. Figure 1 shows the impact of the benchmark procedure for Australia, Italy, Korea, Mexico, Netherlands, New Zealand, Slovenia, Switzerland, and the United States. The main impact relates to the structure of households by Main Source of Income; households classified as mainly relying on wages and salaries in the micro source tend to be reclassified in other household groups (e.g. in households mainly relying on transfers in Australia; in households mainly relying on income from self-employment in Mexico and Slovenia; and in households mainly relying on property income in Italy). The impact is particularly high in Mexico where the share of households mainly relying on wages and salaries is reduced by 11 points, from $72 \%$ to $61 \%$ of all households, and the share of households mainly relying on income from self-employment is increased by 10 points, from $12 \%$ to $22 \%$.

\section{Impact on final results}

Table 1 presents the impact of benchmarking micro totals to national accounts totals on the disparity index and on the ratio of the richest quintile to the lowest quintile. The impact is presented for both income and consumption aggregates. In most countries benchmarking to national accounts totals prior to the classification of households in micro sources increases the disparity index and the inequality between the richest and the poorest households. There are differences in the impacts for income versus consumption.

Regarding income, Italy, and Mexico are the most impacted by the benchmarking procedure. Mexico shows a change in the disparity index due to the benchmarking procedure higher than 20 percentage points and an impact of 3.3 points on the richest to poorest ratio.

Regarding consumption, Mexico, the United States and Slovenia are the most impacted. Slovenia shows a major impact of the benchmarking process with an impact of 1.1 points on the richest to poorest ratio. 
Figure 1: Impact of benchmarking micro income variables on national accounts on the structure of households by Main source of income

Share of the household group of all households with benchmark minus the share of the household group of all households without benchmark (in \%)

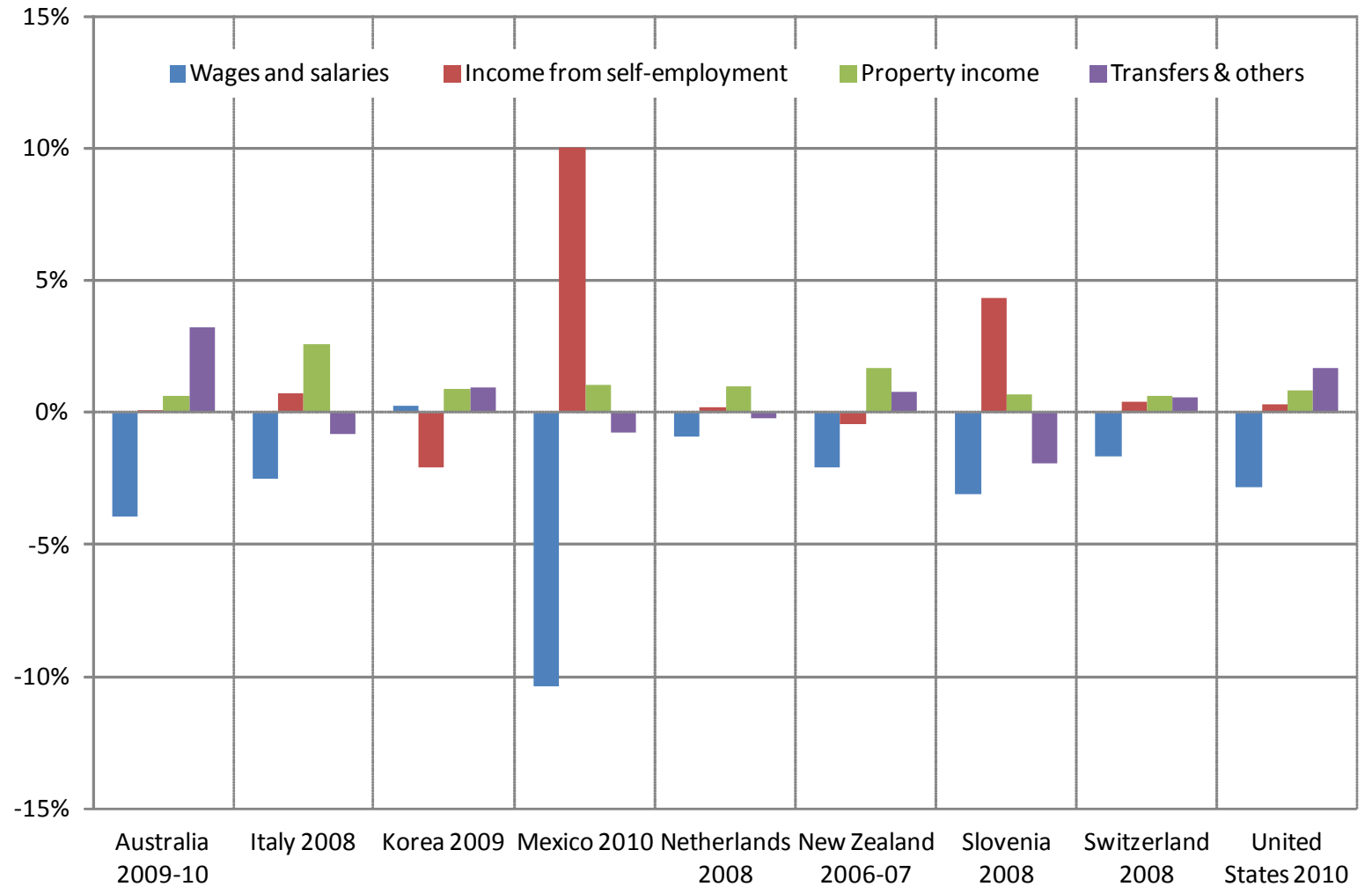

Table 1 - Impact of the benchmark to national accounts prior to households grouping

Adjusted disposable income and actual final consumption per consumption unit

\begin{tabular}{|c|c|c|c|c|c|c|c|}
\hline & & \multicolumn{2}{|c|}{$\begin{array}{l}\text { Disparity index, Equivalized } \\
\text { Disposable Income quintile }\end{array}$} & \multicolumn{2}{|c|}{$\begin{array}{c}\text { Disparity index, Main Source of } \\
\text { Income }\end{array}$} & \multicolumn{2}{|c|}{ Richest to poorest ratio } \\
\hline & & Disparity index & $\begin{array}{l}\text { Impact due to } \\
\text { benchmark }\end{array}$ & Disparity index & $\begin{array}{l}\text { Impact due to } \\
\text { benchmark }\end{array}$ & Ratio & $\begin{array}{l}\text { Impact due to } \\
\text { benchmark }\end{array}$ \\
\hline \multirow{7}{*}{ 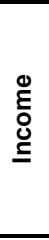 } & \begin{tabular}{|l|} 
Italy 2008 \\
\end{tabular} & $50 \%$ & $10 \%$ & $25 \%$ & $6 \%$ & 3.9 & 0.8 \\
\hline & Korea 2009 & $43 \%$ & $5 \%$ & $18 \%$ & $4 \%$ & 3.5 & 0.3 \\
\hline & Mexico 2010 & $106 \%$ & $23 \%$ & $136 \%$ & $29 \%$ & 13.3 & 3.3 \\
\hline & Netherlands 2008 & $36 \%$ & $1 \%$ & $33 \%$ & $-4 \%$ & 3.2 & 0.4 \\
\hline & New Zealand 2006-07 & $49 \%$ & $4 \%$ & $26 \%$ & $0 \%$ & 3.9 & 0.5 \\
\hline & Slovenia 2008 & $33 \%$ & $6 \%$ & $21 \%$ & $9 \%$ & 2.4 & 0.2 \\
\hline & United States 2010 & $66 \%$ & $3 \%$ & $33 \%$ & $-3 \%$ & 5.4 & 0.4 \\
\hline \multirow{6}{*}{ 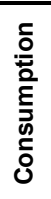 } & Korea 2009 & $9 \%$ & $0 \%$ & $9 \%$ & $0 \%$ & 2.1 & -0.2 \\
\hline & Mexico 2010 & $52 \%$ & $-11 \%$ & $22 \%$ & $6 \%$ & 4.0 & -0.8 \\
\hline & \begin{tabular}{|l|} 
Netherlands 2008 \\
\end{tabular} & $17 \%$ & $-1 \%$ & $9 \%$ & $-1 \%$ & 1.7 & 0.1 \\
\hline & New Zealand 2006-07 & $14 \%$ & $1 \%$ & $14 \%$ & $1 \%$ & 2.0 & 0.0 \\
\hline & Slovenia 2008 & $12 \%$ & $0 \%$ & $12 \%$ & $0 \%$ & 1.3 & -1.1 \\
\hline & United States 2010 & $19 \%$ & $11 \%$ & $19 \%$ & $11 \%$ & 1.7 & -0.1 \\
\hline
\end{tabular}

Note: in Italy, the disparity index measured on the per consumption unit adjusted disposable income equals $50 \%$ when households are classified by income quintiles and that, prior to the grouping of households, micro income totals are benchmarked to national accounts totals. The benchmark process explains 10 percentage points of the disparity index. When no benchmark is applied the disparity index is then $40 \%$. 


\section{Annex 7 - Country comments}

The opportunity has been given to the national experts who performed the breakdown to add specific comments on their country. Comments are presented below.

\begin{tabular}{|c|c|}
\hline \multicolumn{2}{|r|}{ COMMENT } \\
\hline & 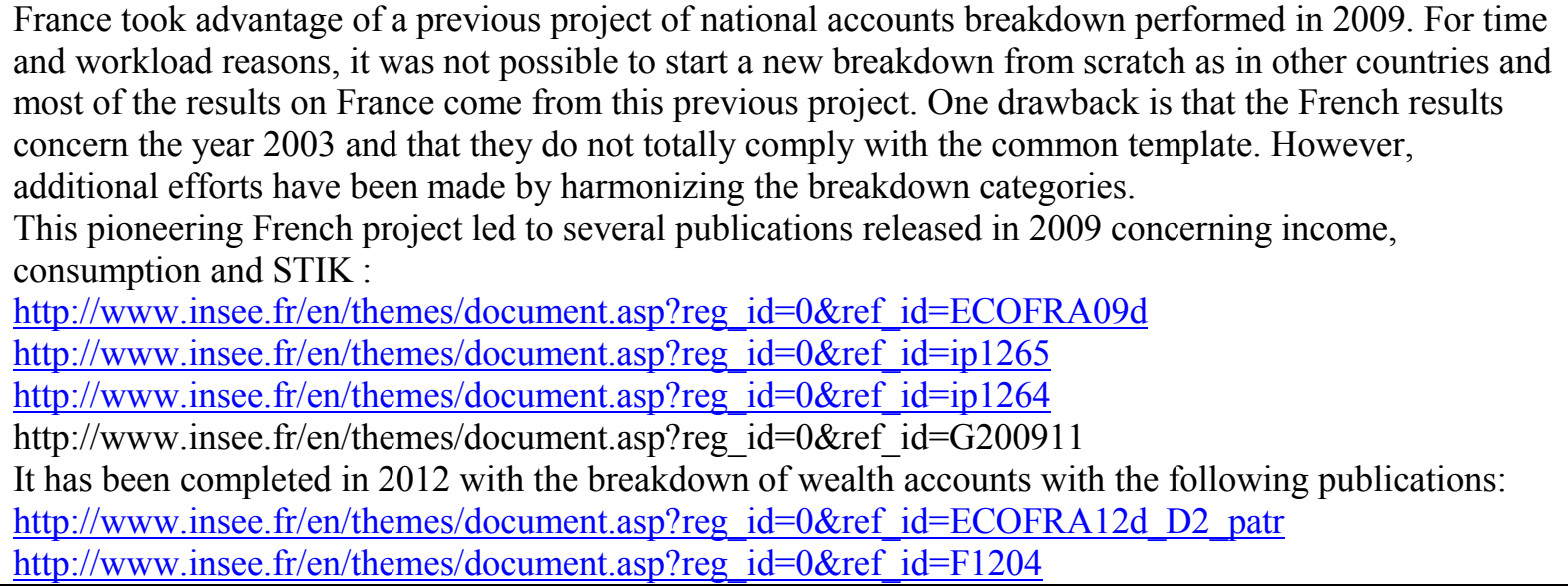 \\
\hline & $\begin{array}{l}\text { Data included in the report is not that which is currently officially released, but rather experimental } \\
\text { compilations for the development of income disparity indicators for the national accounts. Heed of this } \\
\text { fact should thus be taken when interpreting this data. } \\
\text { Moreover, the figures included in the research report are subject to change depending on the estimation } \\
\text { methodology used. } \\
\text { In order for this data to be used as statistics further research will need to be conducted. Therefore, please } \\
\text { cite this data after its reliability has been ensured through further research. }\end{array}$ \\
\hline & $\begin{array}{l}\text { Statistics Sweden (SCB) has not aligned the household structure used from HBS to the Household } \\
\text { finances. There are differences in the population between HBS and the Household finances for the } \\
\text { different subgroups The estimates of distribution of income and consumption are therefore based on } \\
\text { different structures in the household categories. The estimates are therefore based on different structures } \\
\text { in the household categories on the income and consumption side. }\end{array}$ \\
\hline & $\begin{array}{l}\text { Switzerland faced problems by classifying the households (main source of income, equivalized disposable } \\
\text { income) according to the Canberra Group income concept. For instance, interests paid couldn't be taken } \\
\text { into account. This and further slight deviations from a micro (cash) concept probably impact on the results } \\
\text { presented in this paper. } \\
\text { The increasing ratio Q5/Q1 from primary to disposable income (see detailed results available at } \\
\text { http://www.oecd.org/std/WP-STD-2013-4-3.xIsx) is in contradiction with micro source results. The } \\
\text { reason for that is supposed to be related to benchmarking and classifying according to income. } \\
\text { In general, estimating the impact of assumptions to be applied for the breakdown and further } \\
\text { benchmarking procedures (and its combinations) on the final results is difficult. Therefore, Switzerland } \\
\text { applied as few assumptions as possible. } \\
\text { Calculations for Switzerland should be revisited, refined and optimized before results are considered to be } \\
\text { reliable. }\end{array}$ \\
\hline 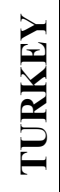 & $\begin{array}{l}\text { This study provided an opportunity for Expert Group members to share and discuss their experiences of } \\
\text { matching macro and micro data on household resources. This is an experimental study and it can be } \\
\text { improved. }\end{array}$ \\
\hline
\end{tabular}

